\title{
Regulation by Glycogen Synthase Kinase-3 Beta of CBP transcriptional coactivator involved in insulin-dependent glucagon gene transcription
}

\author{
Dissertation \\ zur Erlangung des Doktorgrades \\ der Mathematisch-Naturwissenschaftlichen Fakultäten \\ der Georg-August-Universität zu Göttingen
}

vorgelegt von

Andrei Matsiulka

aus Wilejka, Weissrussland

Göttingen 2006 
Diese Arbeit wurde in der Abteilung Molekulare Pharmakologie am Zentrum Pharmakologie und Toxikologie der Georg-August-Universität Göttingen angefertigt.

Die Untersuchungen wurden durch Mittel des Graduiertenkollegs 335 unterstützt.

D 7

Referent : Prof. Dr. R. Hardeland

Korreferent : $\quad$ Prof. Dr. D. Doenecke

Tag der mündlichen Prüfung : 
Meinen Eltern 


\section{CONTENTS}

CONTENTS I

FIGURES and TABLES

ABBREVIATIONS VIII

SUMMARY XI

1. INTRODUCTION

1. 1 Diabetes mellitus 1

1.2 Glucagon and pancreatic islets 2

1. 3 The glucagon promoter 4

1. 3. 1 Regulation by insulin 4

1. 3. 2 Cis-control elements on the glucagon promoter 5

1. 4 Insulin signal trunsduction 6

1. 4. 1 The MAP kinase pathway 8

1. 4. 2 The PI(3)K pathway 8

1.5 Glycogen synthase kinase $3 \quad 9$

1.6 CBP 11

1. 7 Aim of the study 13

2. MATERIALS and METHODS

2. 1 MATERIALS 14

2. 1. 1 Instruments 14

2. 1. 2 Consumables 15

2.1.3 Antibiotics $\quad 15$

2. 1. 4 General Chemicals $\quad 16$

$\begin{array}{ll}\text { 2. } 1.5 \text { Kits } & 17\end{array}$

2. 1. 6 Bacterial culture materials 17

2. 1. 7 Eukaryotic cell line $\quad 18$

2. 1. 8 Eukaryotic cell culture materials $\quad 18$

2.1.9 General buffers and media 18

2. 1. 10 Reporter gene plasmids, constructs and oligonucleotides, $\begin{array}{ll}\text { used in this study } & 19\end{array}$ 
2.1.11 Antibodies, proteins, peptides, molecular weight standards and enzymes

\section{2 METHODS}

2. 2. 1 Standard methods of molecular cloning 24

2. 2. 1 . 1 Preparation of competent Escherichia coli bacteria 24

2. 2. 1. 2 LB-ampicillin agar dishes 24

2. 2. 1. 3 Transformation of competent bacteria 24

2. 2. 1. 4 Mini preparation of plasmid DNA 25

2. 2. 1. 5 Maxi preparation of plasmid DNA 25

2. 2. 1. 6 Measurement of DNA concentration 27

2. 2. 1.7 Restriction enzyme analysis of DNA 27

2. 2. 1. 8 Agarose gel electrophoresis 28

2. 2. 1.9 Purification of DNA from agarose gel 28

2. 2. 1. 10 Dephosphorylation of 5' protruding DNA ends 29

2. 2. 1. 11 Ligation 29

2. 2. 1. 12 Site-Directed Mutagenesis 29

2. 2. 1.13 DNA Sequencing 31

2. 2. 2 Recombinant GST fusion protein expression in bacteria and purification 33

2. 2. 3 Extraction of nuclear proteins 35

2. 2. 4 SDS polyacrylamide gel electrophoresis 36

2. 2. 5 Preparation of proteins for MALDI-TOF mass spectrometry 38

2. 2. 5.1 In-gel digest of proteins stained with Coomassie 38

2. 2. 5. 2 Extraction of peptides from the gel after trypsin digestion 40

2. 2. 5. 3 Cyanogen Bromide cleavage of the peptides after in-gel digestion with trypsin $\quad 41$

2. 2. 6 Immunoprecipitation 41

2. 2. 7 Western Blot Analysis 43

2. 2. 8 EMSA (Electrophoretic mobility shift assay) 44

2. 2. 9 Non-denaturating gel electrophoresis 46

2. 2. 10 Phosphorylation of GST-fusion proteins by recombinant GSK3 $\beta$ in vitro 47

2. 2. 11 Eukaryotic cell culture methods 48

2. 2. 11.1 Cell culture 48

2. 2. 11. 2 DEAE-Dextran transfection 48 
2. 2. 11. 3 Metafectene transfection 49

2. 2. 11. 4 Insulin treatment 50

2. 2.11.5 Cell extract preparation 50

2. 2. 11. 6 Luciferase reporter gene assay 51

2. 2. 11.7 GFP reporter gene assay

2.2.12 Software 52

3. RESULTS

3. 1 Constructs, prepared in this study 53

3. 2 GSK3 $\beta$-induced phosphorylation of C-terminal fragments of CBP in vitro 54

3. 3 Immunoprecipitation of HA-tagged CBP proteins expressed in InR1G9 cells 56

3. 4 Studies on the phosphorylation of CBP(2300-2441) in InR1G9 cells using anti-P-Ser/anti-P-Thr antibodies, under basal conditions, under insulin treatment, and under cotransfection of GSK3 $\beta$ or a kinase-dead GSK3 $\beta$ mutant

3. 5 MALDI-TOF analysis of GST-tagged CBP proteins 62

3. 6 Sequence alignment of the C-terminal part of murine CBP and p300 66

3. 7 Effect of mutations within the C-terminal part of CBP on the $\begin{array}{ll}\text { phosphorylation by GSK3ß in vitro } & 67\end{array}$

3. 8 Effect of mutations within the C-terminal part of CBP on its basal transcriptional activity 69

3.9 Effect of insulin on the transcriptional activity mediated by the wild type CBP and mutated CBP constructs

3.10 Effect of mutations within the C-terminal fragment of CBP on GSK3ß responsiveness

3. 11 Expression levels of GAL4-CBP(2040-2441)WT

and Gal4-CBP(2040-2441)S2424A in InR1G9 cells

\section{DISCUSSION}

$\begin{array}{lr}\text { 4. } 1 \text { GSK3 } \beta \text { substrate specificity } & 81\end{array}$

4. 2 GSK3 $\beta$-induced phosphorylation of CBP $\quad 84$

4. 3 Phosphorylation of CBP sequences that meet the GSK3及 consensus phosphorylation site and are not conserved in p300 86

4. 4 Inhibition by insulin of CBP-mediated transcriptional activity 
4. 5 Mutation of serine 2424 within CBP reduces the activation by GSK3ß $\begin{array}{lr}\text { of glucagon gene transcription } & 88\end{array}$

4. 6 Final concept

4. 7 Pharmacological inhibition of GSK3 - a strategy for the treatment of type 2 diabetes mellitus 


\section{FIGURES and TABLES}

Fig. 1. Pancreatic islets

Fig. 2. Control cis-elements on glucagon promoter and their corresponding transcription factors

6

Fig. 3. Insulin signal transduction 7

Fig. 4. Alignment of human CBP and p300 proteins 12

Fig. 5 Site-directed mutagenesis, general scheme 30

Fig. 6 A typical sequencing electropherogram 32

Fig. 7. Scheme, representing general immunoprecipitation steps 41

Fig. 8. Full-length CBP (Cyclic AMP response element-binding protein (CREB) binding protein) and four C-terminal fragments examined in this study 54

Fig. 9. Recombinant GSK3 $\beta$ phosphorylation of CBP fusion proteins in vitro 55

Fig. 10. Relative phosphorylation of GST-CBP fusion proteins by recombinant GSK3ß in vitro 56

Fig. 11. Immunoprecipitation of HA-tagged CBP(2300-2441) 57

Fig. 12. Studies on the phosphorylation of $\mathrm{CBP}(2300-2441) \mathrm{HA}$ in vivo using anti-P-Ser/anti-P-Thr antibody

Fig. 13. Studies on the phosphorylation of CBP(2300-2441)HA and CREB-HA in vivo using an antiphosphoserine antibody

Fig. 14. Control of the antiphosphoserine and antiphosphothreonine antibodies

Fig. 15. MALDI-TOF spectrum of the GST-CBP(2040-2170) with (B) and without $(A)$ in vitro phosphorylation by GSK3 $\beta$ followed by trypsin digestion

Fig. 16. MALDI-TOF spectrum of the GST-CBP(2300-2441) with (B) and without (A) in vitro phosphorylation by GSK3 $\beta$ followed by trypsin digestion 
Fig. 17. MALDI-TOF spectrum of the GST-CBP(2300-2441) with (B) and without (A) in vitro phosphorylation by GSK3 $\beta$ followed by combined trypsin/CNBr digestion

Fig. 18. Sequence alignment of the C-terminal part of murine CBP and p300

Fig. 19. Effect of mutations within the $\mathrm{C}$-terminal part of CBP on its phosphorylation by GSK3 $\beta$ in vitro

Fig. 20. Effect of mutations within $C B P(2300-2441)$ on its phosphorylation by GSK3 $\beta$ in vitro: densitometry

Fig. 21. Effect of mutations within the C-terminal part of CBP on its basal transcriptional activity, using 5xGAL4(E1B)Luc

Fig. 22. Effect of mutations within the C-terminal part of CBP on its basal transcriptional activity, using $-350(\mathrm{G} 1 \mathrm{~m} / \mathrm{G} 3 \mathrm{~m})$ GluLuc

Fig. 23. Effect of insulin on the transcriptional activity mediated by wild-type GAL4-CBP(2040-2441) and its mutants, using 5xGAL4(E1B)Luc

Fig. 24. Effect of insulin on the transcriptional activity mediated by wild-type GAL4-CBP(2040-2441) and its mutants, using -350(G1m/G3m)GluLuc

Fig. 25. Effect of mutations within the C-terminal fragment of CBP on GSK3 $\beta$ responsiveness, using $5 \times$ GAL4(E1B)Luc

Fig. 26. Effect of mutations within the $C$-terminal fragment of CBP on GSK3 $\beta$ responsiveness, using $-350(G 1 \mathrm{~m} / \mathrm{G} 3 \mathrm{~m})$ GluLuc

Fig. 27. Effect of the mutation of serine 2424 to alanine within the C-terminal part of CBP on the GSK3 $\beta$ WT-induced increase in glucagon gene transcription

Fig. 28. Relative expression of GAL4-CBP(2040-2441)WT and

Gal4-CBP(2040-2441)S2424A in InR1G9 cells

Fig. 29. Schematic representation of two isoforms of GSK3 (A) and example of typical GSK3 phosphorylation event (B)

Fig. 30 Inhibition of glucagon gene transcription by insulin via $\mathrm{PI}(3) \mathrm{K} / \mathrm{PKB} / \mathrm{GSK} 3 \beta$ pathway involving phosphorylated CBP. Working hypothesis: phosphorylation of CBP at serine-2424 may be involved in the regulation by GSK3 $\beta$ of CBP transcriptional activity 
Table 1. Putative GSK3 substrates

Table 2 - Reporter gene plasmids, used in this study

Table 3 - List of the constructs, used in this study

Table 4 - Oligonucleotides, used in this study

Table 5 - List of antibodies, used in this study

Table 6. List of the constructs, prepared in this study

Table 7 - Typical protein substrates of GSK3

83 


\section{ABBREVIATIONS}

aa

$a / b$

Ac

ACN

Ambic

Amp

APS

ATP

bp

BS

BSA

${ }^{\circ} \mathrm{C}$

ca.

cAMP

CBP

CDK

cDNA

$\mathrm{Ci}$

CMV

Cpm

CRE

CREB

$\mathrm{CsCl}$

dCTP

$\mathrm{ddH}_{2} \mathrm{O}$

DEAE

DNA

ddNTP

DTT

E.coli

eg

EDTA

EGTA amino acids

antibody

acetate

Acetonitrile

ammonium bicarbonate

ampicillin

ammonium persulfate

adenosine triphosphate

base pair

Bluescript

bovine serum albumin

celsius degrees

circa

cyclic adenosine-3',5'-monophosphate

CREB binding protein

cyclin dependent kinase

copy deoxyribonucleic acid

curie

cytomegalovirus

counts per minute

cAMP response element

cAMP response element binding protein

cesium chloride

2'-deoxycytidine 5'-triphosphate

double-distilled water

diethylaminoethyl

deoxyribonucleic acid

dideoxy-ribonucleoside-trisphosphate

dithiothreitol

Escherichia coli

for example

ethylenediaminetetraacetic acid

ethylene glycol bis (2-aminoethyl ether)-

$\mathrm{N}, \mathrm{N}, \mathrm{N}$ 'N'-tetraacetic acid 
EMSA

ERK

FFA

FCS

fig.

FKHR

g

GFP

GSK3

GST

h

HA

HEPES

HPLC

IP

IPTG

IRE

IRS

JNK

$\mathrm{kb}$

$\mathrm{kDa}$

L

LB

$\mathrm{M}$

$\mathrm{mA}$

MALDI-TOF

MAPK

$\min$

NFAT

OD

ON

PAGE

PBS

PCR

PDK
Electroforetic Mibility Shift Assay

extracellular signal-regulated kinase

free fatty acids

fetal calf serum

figure

forkhead-related

gram

green fluorescent protein

glycogen synthase kinase 3

glutathione S-transferase

hour or hours

hemagglutinin

4-(2-hydroxyethyl)-1-piperazineethanesulfonic

acid

High performance liquid chromatography

immunoprecipitation

isopropyl-thio-galactoside

insulin-responsive element

insulin receptor substrate

c-Jun amino-terminal kinase

kilobases

kilodalton

liter

laura bertani

Mole

milliampere

Matrix-assisted laser desorption/ionization

time-of-flight mass spectrometry

mitogen-activated protein kinase

minute or minutes

nuclear factor of activated T-cells

optical density

overnight

polyacrylamide gel electrophoresis

phosphate-buffered saline

polymerase chain reaction

phosphatidylinositol-dependent kinase 


\begin{tabular}{|c|c|}
\hline PEG & polyethylene glycol \\
\hline PEPCK & phosphoenolpyruvate carboxykinase \\
\hline $\mathrm{PH}$ & pleckstrin homology \\
\hline $\mathrm{PI}$ & phosphatidylinositol \\
\hline $\mathrm{PI}(3) \mathrm{K}$ & phosphatidylinositol-3-OH-kinase \\
\hline PISCES & $\begin{array}{l}\text { pancreatic islet cell-specific } \\
\text { sequence }\end{array}$ \\
\hline PKA & protein kinase $A$ \\
\hline PKB & protein kinase $B$ \\
\hline PMSF & phenylmethyl-sulfonylfluoride \\
\hline RNase & ribonuclease \\
\hline Rpm & rotations per minute \\
\hline RT & room temperature \\
\hline SDS & sodium-dodecyl-sulfate \\
\hline $\sec$ & seconds \\
\hline SEM & standard error of the mean \\
\hline Shc & Src homologous and collagen-like protein \\
\hline STE & sucrose-TRIS-EDTA \\
\hline TAD & transactivation domain \\
\hline TAE & tris-acetate-EDTA \\
\hline TBE & tris-borate-EDTA \\
\hline TBS & tris-buffered saline \\
\hline TCA & trichloroacetic acid \\
\hline TE & tris-EDTA \\
\hline TEMED & N', N', N', N'-tetramethyldiamine \\
\hline TFA & trifluoroacetic Acid \\
\hline Tris & tris-(hydroxymethyl)-aminomethane \\
\hline Tween-20 & polyoxyethylen-sorbit-monolaurate \\
\hline$U$ & unit (enzymatic activity) \\
\hline UV & ultraviolet \\
\hline V & volts \\
\hline Vol & volume \\
\hline $\mathrm{v} / \mathrm{v}$ & volume per volume \\
\hline W & watt \\
\hline$w / w$ & weight per volume \\
\hline
\end{tabular}




\section{SUMMARY}

The peptide hormone glucagon is a functional antagonist of insulin and it stimulates glucose output from the liver. Insulin inhibits glucagon secretion and glucagon gene transcription. Insulin resistance leads to hyperglucagonemia contributing to impaired glucose tolerance in diabetes mellitus type 2. Previous studies suggested that the insulininduced inhibition of the glucagon gene involves glycogen synthase kinase $3 \beta$ (GSK3 $\beta$ ). CBP was shown to be crucial for the activation of the glucagon gene in the alpha cells and to be phosphorylated in vitro by GSK3 $\beta$ on its C-terminal end. In the present study GSK3 $\beta$ phosphorylation sites within the C-terminus of CBP were mapped and their functional significance in the regulation of glucagon gene transcription was investigated.

An in vitro kinase assay using three C-terminal CBP fragments was performed. Even in the absence of a priming phosphorylation by another kinase, recombinant GSK3 $\beta$ phosphorylated a GST-fused C-terminal fragment of CBP consisting of amino acids 23002441. Two methods, MALDI-TOF mass spectrometry and immunoprecipitation followed by phosphor-specific immunoblot, were used and found not to be suitable to study phosphorylation in vivo.

Computer analysis, utilizing the GSK3 $\beta$ substrate recognition sequence and a sequence comparison between CBP and its closely related homologue $\mathrm{p} 300$, provided evidence that serine-2420 and serine-2424 might serve as potential GSK3 $\beta$ targets. Subsequently, these sites were mutated to alanine and the respected GST-fused proteins were subjected to the in vitro kinase assay with recombinant GSK3 $\beta$. The results obtained showed that the introduced mutations markedly reduced the phosphorylation of CBP (2300-2441) by GSK3ß.

In order to test the functional significance of the discovered GSK3 $\beta$-target sites, transient transfection assays were performed. CBP, containing mutated serine-2424, conferred a significantly reduced activation by GSK3 $\beta$ to the glucagon gene. The CBP-S2420Amediated activation by GSK3 $\beta$ was unimpaired. The insulin-induced inhibition of CBP transcriptional activity of the glucagon gene was not relieved by these mutations.

Taken together, the results of the present study show that serine-2424 of CBP is phosphorylated by GSK3 $\beta$ in vitro and confers GSK3 $\beta$ activation of the glucagon gene in vivo. The phosphorylation of CBP by GSK3 $\beta$ might stabilize the nucleoprotein complex on the glucagon gene. Through inhibition of GSK3, insulin might repress gene transcription by disruption of a glucagon promoter-specific protein complex. The fact, that the mutation of serine-2424 was not sufficient to mimic the inhibitory effect of insulin on the glucagon gene transcription, suggests that additional GSK3 $\beta$ phosphorylation sites exist. 


\section{Introduction}

\section{1 Diabetes mellitus}

Diabetes mellitus (DM), long considered a disease of minor significance to world health, is now taking its place as one of the main threats to human health in the 21st century (Zimmet et al., 2001). It is the most common non-communicable disease worldwide and the fourth to fifth leading cause of death in developed countries. The global figure of people with diabetes is set to rise from the current estimate of 150 million to 220 million in 2010 and 300 million in 2025 (King et al., 1998).

There are two major forms of diabetes: type 1 and type 2 diabetes mellitus. The World Health Organisation and the American Diabetics Association have proposed that type 1 diabetes can be divided into autoimmune/immune-mediated diabetes (Type $1 \mathrm{~A}$ ) and idiopathic diabetes with $\beta$-cell obstruction (Type 1B). People with type 1 diabetes mellitus must take exogenous insulin for their survival. Type 1 diabetes mellitus frequency is low relative to type 2 diabetes, which accounts for over $90 \%$ of cases globally. Type 2 diabetes mellitus is linked with the peripheral insulin resistance, decrease in beta-cell mass, abnormal insulin secretion and increased glucose production. Distinct genetic and metabolic defects in insulin secretion/action give rise to the common phenotype of hyperglycemia (Tripathi and Srivastava, 2006).

Type 2 diabetes mellitus is made up of different forms, each of which is characterized by a variable degree of insulin resistance and $\beta$-cell dysfunction. People with type 2 diabetes mellitus might be not dependent on exogenous insulin, but may require it for the control of blood glucose levels if this is not achieved with diet alone or with oral hypoglycemic agents. This type of diabetes mellitus accounts for 90 to $95 \%$ of all diabetic patients. All forms of diabetes mellitus are characterized by chronic hyperglycemia and the development of diabetes-specific microvascular defects in the retina, renal glomerulus, and peripheral nervous system. As a consequence, diabetes is the leading cause of blindness, end-stage renal disease, and a variety of neuropathies (DeFronzo, 1997).

Insulin resistance is a characteristic feature of most patients with type 2 diabetes mellitus and is almost a universal finding in type 2 diabetic obese patients. In obese subjects, insulin levels typically increase to maintain normal glucose tolerance. Basal and total 24-h rates of insulin secretion are three to four times higher in obese insulin-resistant subjects than in lean controls (Reaven, 1988). The hyperinsulinemia associated with insulin resistance results from a combination of an increase in insulin secretion and biosynthesis, and a reduction in insulin clearance rates as well as increased beta-cell mass on this step of the disease. 
Insulin resistance is characterized by defects at many levels in insulin signalling, with decreases in receptor concentration and kinase activity, the concentration and phosphorylation of insulin receptor substrate-1 (IRS-1) and insulin receptor substrate-2 (IRS-2), phosphatydilinositol-3-kinase $(\mathrm{PI}(3) \mathrm{K})$ activity, glucose transporter translocation, and the activity of intracellular enzymes (Kido et al., 2000). Insulin increases glucose transport in fat and muscle cells by stimulating the translocation of the transporter GLUT4 from intracellular sites to the plasma membrane. GLUT4 is found in vesicles that continuously cycle from intracellular stores to the plasma membrane. Insulin increases glucose transport by increasing the rate of GLUT4 vesicle exocytosis and by slightly decreasing the rate of internalization (Pessin et al., 1999).

Circulating free fatty acids (FFAs) derived from adipocytes are elevated in many insulinresistant states and have been suggested to contribute to the insulin resistance of diabetes mellitus and obesity by inhibiting glucose uptake, glycogen synthesis, and glucose oxidation and by increasing hepatic glucose output. Elevated FFAs are also associated with a reduction in insulin-stimulated IRS-1 phosphorylation and IRS-1associated PI3K activity. The link between increased circulating FFAs and insulin resistance might involve accumulation of triglycerides and fatty acid-derived metabolites (diacylglycerol, fatty acyl-CoA and ceramides) in muscle and liver. In addition to its role as a storage depot for lipid, the fat cell produces and secretes a number of hormones, collectively called adipokines, which may profoundly influence metabolism and energy expenditure. Expression of tumor necrosis factor alpha (TNF- $\alpha$ ) is increased in the fat of obese rodents and humans and has been shown to produce serine phosphorylation of IRS-1, resulting in reduced insulin receptor kinase activity and insulin resistance (Hotamisligil et al., 1996).

Recently, it has been shown that the c-Jun amino-terminal kinases (JNKs) are among the crucial mediators of obesity and insulin resistance. Since both FFA's and TNF- $\alpha$ are potent activators of JNKs, it provides an additional link for the understanding of obesityinduced insulin resistance (Hirosumi et al., 2002).

\section{2 Glucagon and pancreatic islets}

Plasma glucose levels remain in a narrow range between 4 and $7 \mathrm{mM}$ in healthy individuals. This is controlled by the balance between glucose absorption from the intestine, production by liver and uptake and metabolism by peripheral tissues. The main regulators of the glucose homeostasis are two pancreatic hormones: insulin and glucagon. Glucagon is a 29 amino acid peptide hormone liberated in the a-cells of the 
islets of Langerhans (Unger and Orci, 1981) and stimulates glucose output from the liver through glycogenolysis, gluconeogenesis and ketogenesis thus supplying body organs with energetic material (Knepel, 2001; Jiang and Zhang, 2003). The action of glucagon in the liver is complex and involves coordinate regulation of transcription factors and signal transduction networks which converge on regulation of amino acid, lipid and carbohydrate metabolism (Vidal-Puig and O'Rahilly, 2001; Herzig et al., 2003). Insulin, being the biological antagonist of glucagon, inhibits hepatic glucose production and increases glucose uptake in muscle and fat cells by stimulating the translocation of the transporter GLUT4 from intracellular stores to the plasma membrane (Zick, 2001).

In mammals, a single glucagon gene encodes a larger biosynthetic precursor, proglucagon. One of the interesting features of proglucagon gene expression is the utilization of different tissue-specific promoter elements for regulation of gene expression in islets, intestine and brain. Furthermore, there is species-specificity in promoter utilization, lending additional complexity. Whereas $\sim 1250$ nucleotides of the rat proglucagon gene promoter directs transgene expression to the CNS and pancreatic $\alpha$ cells (Efrat et al., 1998), additional upstream sequences extending to -2250 are required for expression in intestinal endocrine cells (Lee et al., 2002).

The islets of Langerhans contain glucagon-secreting $\alpha$-cells, insulin-secreting $\beta$-cells and somatostatin-secreting $\delta$-cells. These cells are characterised by membrane specialisations involving tight junctions, desmosomes and gap junctions. Molecules smaller than $1000 \mathrm{Da}$ can move from the cytoplasm of one cell to that of another through the gap junctions without entering the intercellular space. Such junctions have been found between $\alpha$ - and $\beta$-cells (Orci and Unger, 1975; Orci et al., 1975; Meda et al., 1982), as well as between $\delta$-cells and $\alpha$ - or $\beta$-cells (Unger et al., 1978; Michaels and Sheridan, 1981; Meda et al., 1982). 


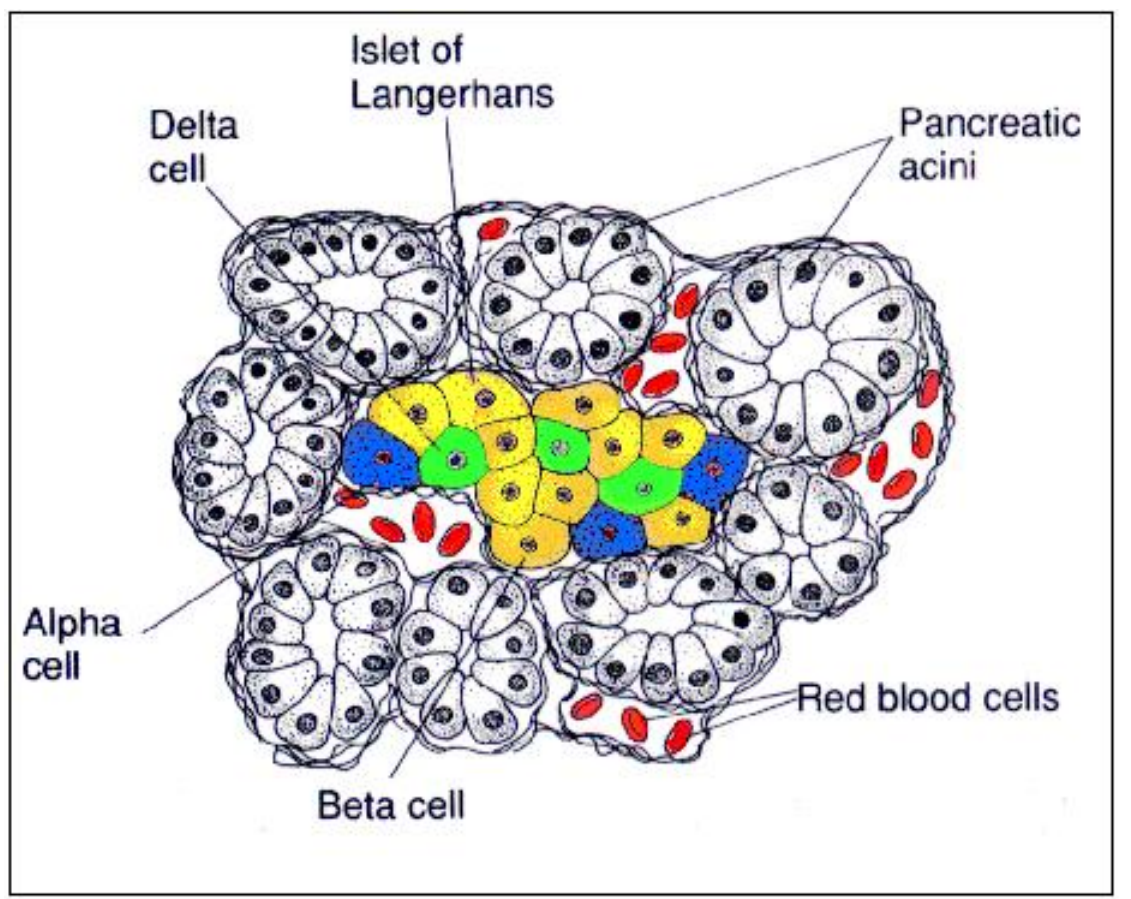

Fig. 1. Pancreatic islets

The endocrine pancreas is constituted of distinct cell types: the a-cells (blue) in the periphery which produce glucagon, the $\beta$-cells (yellow) located in the centre which produce insulin and the $\delta$-cells (green) that produce somatostatin (Dimopoulos N., PhD Thesis, 2003).

\section{3 The glucagon gene promoter}

\section{3. 1 Regulation by insulin}

Experiments using transgenic mice (Efrat et al., 1988; Lee et al., 1992), cell-free in vitro transcription systems (Knepel, 1993) and tumor cell lines (Drucker et al., 1987; Philippe et al., 1988) suggest that pancreatic $\alpha$-cell specific activation of the glucagon gene is regulated through the 5 'flanking region. A reporter fusion gene containing 350 base pairs of the glucagon promoter is sufficient to drive expression of glucagon gene in glucagonproducing islet tumor cell lines (Philippe et al., 1988) and to confer insulin responsiveness (Philippe, 1989). Initially, it has been suggested that the effects of insulin on various genes are mediated through a common transcription factor that binds to an insulin-responsive element (IRE) (Alexander-Bridges et al., 1992). IREs have been characterized in a number of genes, but it became apparent that unlike cAMP, which regulates transcription through a single CRE element (Meyer and Habener, 1993), in the case of insulin a single consensus IRE does not exist (O' Brien and Granner, 1996; Chapman et al., 1999). Therefore, although many candidates have been proposed so far to mediate insulin 
responsiveness depending on the context of each gene e.g. FKHR (Durham et al., 1999), Egr-1 (Barroso and Santisteban, 1999), SRF (Thompson et al., 1994), the possibility that insulin could also act independently of an IRE by targeting an array of transcription factors at the coactivator level cannot be excluded (Leahy et al., 1999; Pierreux et al., 1999). Particularly, in the case of the glucagon gene, it has been suggested that an enhancer-like element called G3 could also act as an IRE (Philippe, 1991). However, recent studies failed to identify a single IRE in the glucagon promoter and indicate that insulin responsiveness might rather be due to the synergistic interaction of both proximal promoter and more distal enhancer-like elements with Pax6 and its potential coactivator CREB-binding protein (CPB) being critical components (Grzeskowiak et al., 2000). Glucagon gene expression seems to be controlled by insulin at the transcriptional level through the $\mathrm{PI}(3) \mathrm{K} / \mathrm{PKB}$ pathway (Schinner et al., 2005) and further through GSK3 $\beta$ (Dimopoulos N., PhD Thesis, 2003).

\section{3. 2 Cis-control elements within the glucagon promoter}

Substantial amount of data has accumulated concerning the regulation of glucagon gene expression by various transcription factors. By deletional, linker-scanning and DNase I footprint analyses major cis-regulatory elements in the -350 '-flanking region of the glucagon gene have been identified, which allowed to characterize many trans-acting nuclear proteins (reviewed in Knepel, 2001). Transcriptional control elements can be further subdivided into two groups: proximal promoter elements encompassing $\mathrm{G} 1$ and G4, and the so called more distal enhancer-like elements including G2, G3 and CRE (Fig. 2 ). The proximal promoter region (base pairs -136 to +58 ) has low transcriptional activity of its own, but is required to mediate activation of transcription by $\mathrm{G} 2$ and $\mathrm{G} 3$ and may play a role in restricting expression to a-cell phenotype cell lines (Philippe et al., 1988; Morel et al., 1995).

Recently, it has been shown that the carboxy-terminal domain of Pax6 interacts with the co-activator p300/CBP (Hussain and Habener, 1999), suggesting that recruitment of CBP might be important for the function of Pax 6 and the rearrangement of other transcription factors to access the general transcriptional machinery on the glucagon gene promoter. 


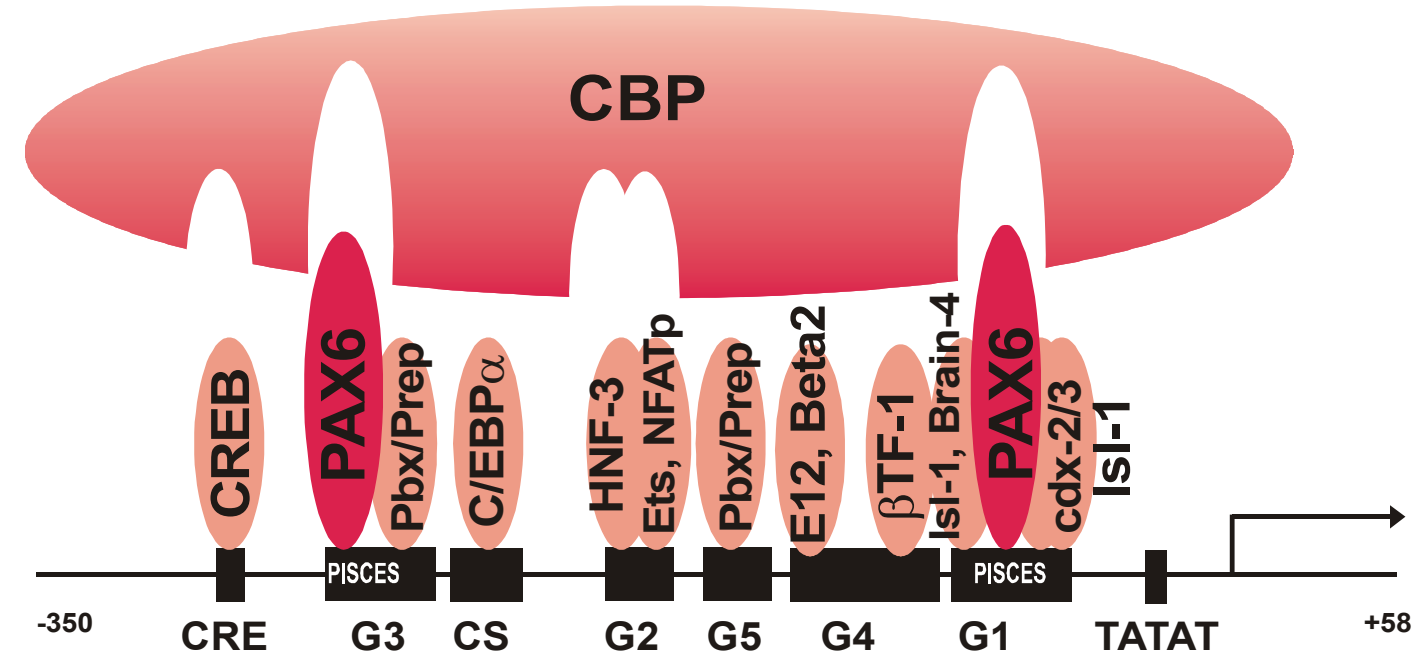

Fig. 2. Control cis-elements within the glucagon promoter and their corresponding

\section{transcription factors}

The schema represents most of the so far identified transcription factors that are known to bind to characterized control cis-elements within the glucagon promoter.

\section{4 Insulin signal transduction}

At the molecular level, insulin binding to its transmembrane receptor (IR) stimulates the intrinsic tyrosine kinase activity of the receptor which then phosphorylates target proteins such as Shc and the family of insulin receptor substrate (IRS) proteins (IRS-1 to IRS-4) on selective tyrosine residues that serve as docking sites for downstream effector molecules. This triggers two major kinase cascades, the $\mathrm{PI}(3) \mathrm{K}$ and the mitogen-activated protein (MAP) kinase pathways, which mediate the metabolic and growth-promoting functions of insulin (Virkamaki et al., 1999) (Fig. 3). 


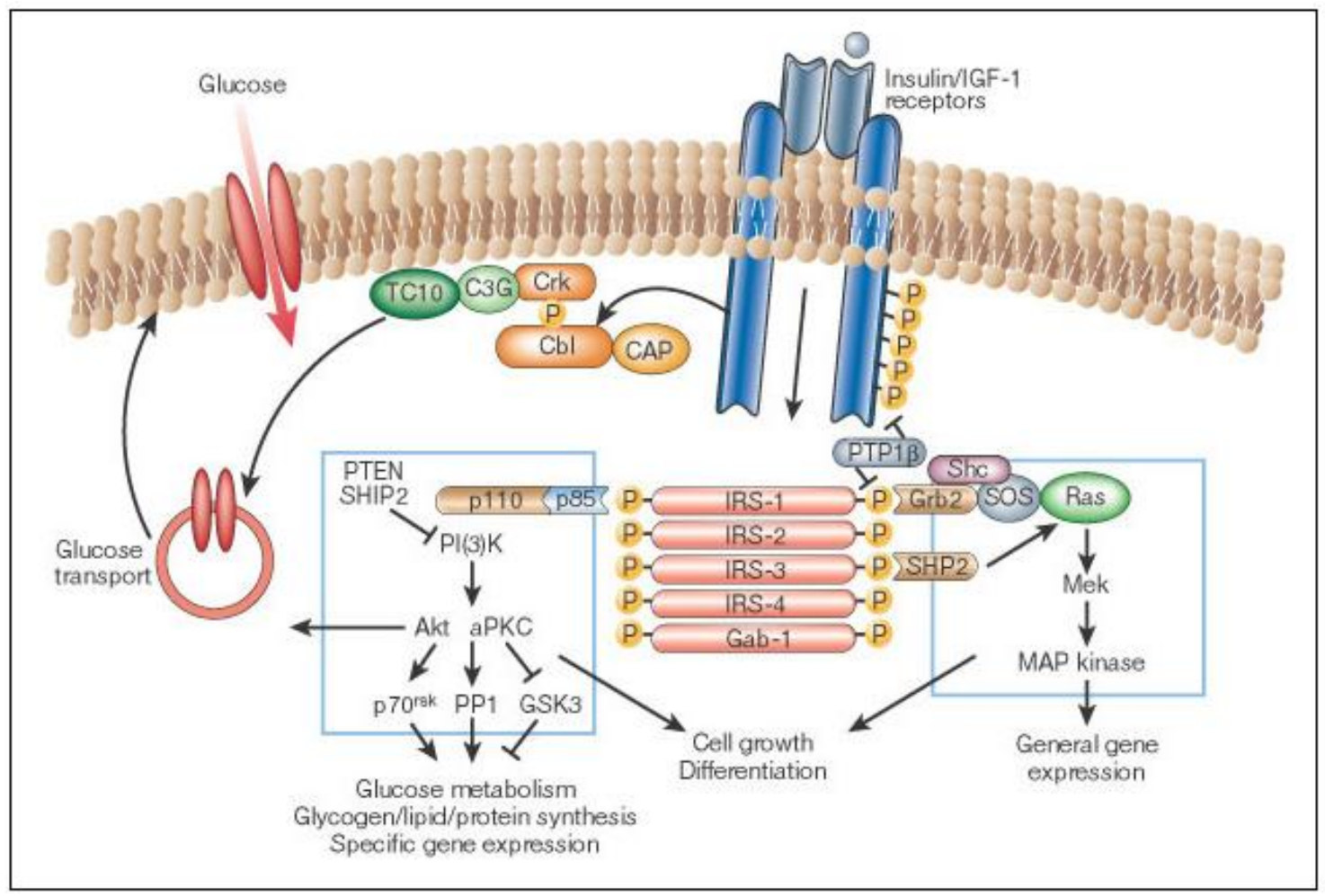

Fig. 3. Insulin signal transduction Nature (2001); 414: 799-806

Circulating insulin interacts with its cognate receptor, which is a transmembrane tyrosine kinase, having an $\alpha_{2} \beta_{2}$ configuration (Kellerer, 1999). Insulin binding to the a subunits leads to a conformational change and stimulation of the receptor kinase activity through autophosphorylation of tyrosine residues in the $\beta$ subunits. The activated insulin receptor kinase (IRK) then phosphorylates substrate proteins, such as Shc, Gab-1, CbI/CAP and the family of insulin receptor substrate (IRS) proteins, on selective tyrosine residues that serve as docking sites for downstream effector molecules. This triggers two major kinase signaling cascades - the mitogen-activated protein kinase (MAPK) and phosphoinositide 3-kinase (PI3K) pathways. Recruitment of the proteins Grb-2 and Sos to Tyrphosphorylated Shc activates the MAPK cascade, whereas association of PI3K with the IRS proteins (IRS-1 to IRS-4) results in production of phosphatidylinositol $(3,4,5)$ trisphosphate $\left(\mathrm{PIP}_{3}\right)$ that activates PDK1 (PI3K-dependent kinase 1) and its downstream effector kinases PKB (protein Ser/Thr kinase B, also named Akt), mTOR, p70S6 kinase and the atypical isoforms of PKC (PKC /PKC $\lambda$ ). Collectively, these kinase cascades mediate the metabolic and growth-promoting functions of insulin, such as translocation of vesicles containing GLUT4 glucose transporters from intracellular pools to the plasma membrane, stimulation of glycogen and protein synthesis, and initiation of specific gene transcription (Virkamaki et al., 1999; Le Roith and Zick, 2001). Phosphorylation of Cbl mediates glucose transport in a PI3K-independent manner (Pessin and Saltiel, 2000). 


\section{4. 1 The MAP kinase pathway}

As is the case for other growth factors, insulin stimulates the mitogen-activated protein (MAP) kinase extracellular signal-regulated kinase (ERK). This pathway involves the tyrosine phosphorylation of IRS proteins and/or Shc, which in turn interact with the adapter protein Grb2, recruiting the Son-of-sevenless (SOS) exchange protein to the plasma membrane for activation of Ras. The activation of Ras also requires stimulation of the tyrosine phosphatase SHP2, through its interaction with receptor substrates such as Gab-1 or IRS1/2. Once activated, Ras operates as a molecular switch, stimulating a serine cascade through the stepwise activation of Raf, MEK and ERK1/2 (Kyriakis, 1992). Activated ERK can translocates into the nucleus, where it catalyses the phosphorylation of transcription factors such as $\mathrm{p} 65^{\mathrm{tcf}}$, initiating a transcriptional programme that leads to cellular proliferation or differentiation (Boulton et al., 1991). Blockade of the pathway with pharmacological inhibitors prevents the stimulation of cell growth by insulin, but has no effect on the metabolic actions of the hormone (Lasar et al., 1995).

\section{4. 2 The $\mathrm{PI}(3)$-kinase pathway.}

Downstream of IRS-proteins, the PI-3-kinase is a central mediator of the effects of insulin. $\mathrm{PI}(3)$-kinase isoforms can be subdivided into three classes. Class la PI(3)-kinases are thought to be the major effector of insulin signalling and activate PKB by the generation of 3'-phosphoinositides [phosphatidyl-inositol-3,4- bisphosphate (PIP2) and phosphatidylinositol-3,4,5-trisphosphate (PIP3)]. Class Ib is a G-protein-regulated kinase. Class II $\mathrm{PI}(3)$-kinases can be activated by insulin, but are unable to generate PIP2 and PIP3, therefore it is unlikely that they mediate common insulin effects. Also, class III PI(3)kinases appear not to play a role in insulin signalling. Binding of $\mathrm{PI}(3)$-kinase to phosphorylated sites in IRS proteins leads to activation of PI(3)-kinase. The activated PI(3)-kinase generates PIP2 and PIP3 (Alessi and Cohen, 1998). PIP2 and PIP3 bind to the phosphoinositide-dependent kinase 1 (PDK1). Therefore, these two phospholipids may attract PDK1 and the putative PDK2 to the plasma membrane. Known substrates of the PDKs are proteinkinase $B(P K B)$ and also atypical forms of protein kinase $C$ (PKC) (Kotani et al., 1998). PKB is a serine/threonine kinase with high homology to PKA and PKC, hence the name. So far, three different isoforms of PKB have been identified in mammals (PKB- $\alpha$, PKB- $\beta$, PKB- $\gamma$ ). PKB is conserved from invertebrates to mammals and shows high homology among different species emphasizing its pivotal role in development, cell proliferation and metabolism (Vanhaesebroek and Alessi, 2000). PKB 
mediates the effects of insulin on glucose transport, glycogen synthesis, protein synthesis, lipogenesis and suppression of hepatic gluconeogenesis. Recently, it has been shown that PKB mimics insulin action in the pancreatic glucagon-producing cell line InR1G9 (Schinner et al., 2005). PKB regulates both, glucose uptake via facilitated glucose transporters (GLUTs) and intracellular glucose metabolism in insulin sensitive tissues such as skeletal muscle (Alessi and Cohen, 1998). Under non-stimulated conditions, PKB is located in the cytoplasm and stimulation with insulin results in translocation of PKB to the plasma membrane, where PKB may bind to PIP2 and PIP3 (Kohn et al., 1996). At the plasma membrane, PKB co-localizes with PDK and becomes activated by phosphorylation of its two principal regulatory sites, Thr308 and Ser473. Phosphorylation of both sites is essential for the activation of PKB. PDK1 is the kinase phosphorylating Thr308, while the mechanism of phosphorylation of the Ser473 residue remains controversial and the corresponding kinase PDK2 still needs to be identified (Hill et al., 2001). Following activation, PKB detaches from the plasma membrane to affect metabolic processes such as glycogen synthesis and glucose transport. Activated PKB also translocate through the cytoplasm into the nucleus by an unknown mechanism to affect gene expression. Substrates for a direct phosphorylation by PKB include the GSK3 $\beta$ (glycogen synthase kinase-3 beta) and members of the Foxo-family of transcription factors which are critically involved in the insulin-dependent regulation of glucose homeostasis (Vanhaesebroek and Alessi, 2000; Andjelkovic et al., 1997; Meier et al., 1997).

\section{5 Glycogen synthase kinase 3}

After binding to its receptor, insulin via PKB phosphorylates GSK3 at a serine residue near the amino terminus (Ser21 for GSK3 $\alpha$ and Ser9 for GSK3 $\beta$ ). This results in inhibition of the catalytic activity, since the amino terminus is transformed into a "pseudosubstrate" inhibitor, the phosphoserine occupies the same binding site as the priming phosphate of the substrate and thus it blocks access to the active site (Cohen and Frame, 2001).

GSK3 is a serine/threonine kinase that was identified and named as one of several kinases that phosphorylate and inactivate glycogen synthase, the rate limiting enzyme that catalyses the last step in glycogen synthesis (Frame and Cohen, 2001).

There are two mammalian isoforms, which are encoded by distinct genes: GSK3 $\alpha$ (51 $\mathrm{kDa})$ and GSK3 $\beta$ (47 kDa). The difference in size is due to a glycine-rich extension at the $\mathrm{N}$-terminus of GSK3 $\alpha$. Within their kinase domain they share $98 \%$ identity and isoforms from distant species such as flies and humans display $>90 \%$ sequence similarity within 
the kinase domain (Doble and Woodgett, 2003). Although both isoforms are structurally highly similar, it became apparent that one cannot compensate always for the other e.g. GSK3 $\beta$-/- mice die in utero due to extensive hepatocyte apoptosis (Hoeflich et al., 2000). The inability of GSK3a to rescue the above phenotype indicates that the degenerative liver phenotype arises specifically from the loss of the beta isoform. On the other hand, it is the alpha isoform that has been implicated in the regulation of Alzheimer's disease amyloid- $\beta$ peptides using RNAi (Phiel et al., 2003).

Analysis of the GSK3 $\beta$ structure suggests a mechanism of activation coupled to binding of phosphorylated substrates. Protein kinases, related to GSK3 $\beta$, such as $p 38 y$ require phosphorylation of residues in their activation loops (T-loops) to become active. A phosphothreonine is used to align key $\beta$-strand and $\alpha$-helical domains. The T-loop of GSK3 $\beta$ is tyrosine phosphorylated (pY216) in resting cells (Hughes et al., 1993; Hartigan et al., 2001; Lesort et al., 1999) but not threonine. Although the physiological significance of Y216 phosphorylation is not yet clear, it might facilitate substrate phosphorylation, but is not strictly required for kinase activity. Activation of GSK3 seems to be analogous to that of MAPKs except that the active conformation is induced not by phosphorylation, but when the phosphorylated residue of a primed substrate binds to a positively charged pocket comprising R96, R180 and K205 for GSK3 $\beta$ (Doble and Woodgett, 2003; Cohen and Frame, 2001).

Some GSK3 substrates are listed in Table 1.

\begin{tabular}{|c|c|c|c|}
\hline $\begin{array}{l}\text { Putative } \\
\text { substrate }\end{array}$ & Function & Effect of phosphorylation & References \\
\hline Glycogen synthase & $\begin{array}{l}\text { Glycogen } \\
\text { synthesis }\end{array}$ & Inhibits enzymatic activity & $\begin{array}{l}\text { Dent et al., } \\
1989 \text {; Fiol et } \\
\text { al., } 1988\end{array}$ \\
\hline elF2B & $\begin{array}{l}\text { Protein } \\
\text { synthesis }\end{array}$ & Inhibits enzymatic activity & $\begin{array}{l}\text { Welsh and } \\
\text { Proud, } 1993\end{array}$ \\
\hline ATP citrate lyase & $\begin{array}{l}\text { Fatty acid } \\
\text { synthesis }\end{array}$ & Inhibits enzymatic activity & $\begin{array}{l}\text { Hughes et al., } \\
1992\end{array}$ \\
\hline Axin & Wnt signalling & Stabilizes protein and recruits $\beta$ s-catenin & $\begin{array}{l}\text { Ikeda et al., } \\
1998 \text {; Jho et } \\
\text { al., } 1999\end{array}$ \\
\hline$\beta$-catenin & Wnt signalling & Targets for degradation & $\begin{array}{ll}\text { Yost et al., } \\
1996\end{array}$ \\
\hline APC & Wnt signalling & Facilitates binding of $\beta$-catenin to APC & $\begin{array}{l}\text { Rubinfeld et al., } \\
1996\end{array}$ \\
\hline MUC1/DF3 & Glycoprotein & Decreases affinity for $\beta$-catenin & Li et al., 1998 \\
\hline Cyclin D1 & $\begin{array}{l}\text { Cell division } \\
\text { cycle }\end{array}$ & $\begin{array}{l}\text { Promotes nuclear export and targets for } \\
\text { degradation }\end{array}$ & $\begin{array}{l}\text { Diehl et al., } \\
1998\end{array}$ \\
\hline
\end{tabular}




\begin{tabular}{|c|c|c|c|}
\hline C-Jun & $\begin{array}{l}\text { Transcription } \\
\text { factor }\end{array}$ & Inhibits DNA binding and transactivation & $\begin{array}{l}\text { Boyle et al., } \\
1991\end{array}$ \\
\hline c-Myc & $\begin{array}{l}\text { Transcription } \\
\text { factor }\end{array}$ & Targets for degradation & $\begin{array}{l}\text { Pulverer et al., } \\
1994\end{array}$ \\
\hline NFATc & $\begin{array}{l}\text { Transcription } \\
\text { factor }\end{array}$ & $\begin{array}{l}\text { Promotes nuclear export; inhibits DNA } \\
\text { binding }\end{array}$ & $\begin{array}{l}\text { Beals et al., } \\
1997\end{array}$ \\
\hline C/EBPa & $\begin{array}{l}\text { Transcription } \\
\text { factor }\end{array}$ & Not well studied & $\begin{array}{l}\text { Ross et al., } \\
1999\end{array}$ \\
\hline CREB & $\begin{array}{l}\text { Transcription } \\
\text { factor }\end{array}$ & Inhibits DNA binding & $\begin{array}{l}\text { Grimes and } \\
\text { Jope, } 2001\end{array}$ \\
\hline HSF-1 & $\begin{array}{l}\text { Transcription } \\
\text { factor }\end{array}$ & Inhibits DNA binding and transactivation & Chu et al., 1996 \\
\hline GATA4 & $\begin{array}{l}\text { Transcription } \\
\text { factor }\end{array}$ & Suppresses nuclear expression & $\begin{array}{l}\text { Morisco et al., } \\
2001\end{array}$ \\
\hline Tau & $\begin{array}{l}\text { Microtubule } \\
\text { binding-protein }\end{array}$ & Inhibits binding to microtubules & $\begin{array}{l}\text { Hanger et al., } \\
1992\end{array}$ \\
\hline MAP1B & $\begin{array}{l}\text { Microtubule } \\
\text { binding-protein }\end{array}$ & Maintains microtubular instability & $\begin{array}{l}\text { Garcia-Perez et } \\
\text { al., } 1998\end{array}$ \\
\hline Presenilin-1 & $\begin{array}{l}\text { Transmembrane } \\
\text { protein }\end{array}$ & $\begin{array}{l}\text { Increases degradation of C-terminal } \\
\text { fragments }\end{array}$ & $\begin{array}{l}\text { Kirschenbaum } \\
\text { et al., } 2001\end{array}$ \\
\hline IRS-1 & Insulin signalling & Inhibits insulin signalling & $\begin{array}{l}\text { Eldar- } \\
\text { Finkelman and } \\
\text { Krebs, } 1997\end{array}$ \\
\hline Inhibitor-2 & $\begin{array}{l}\text { Regulatory } \\
\text { subunit of } \\
\text { phosphatase }\end{array}$ & Activates phosphatase & $\begin{array}{l}\text { Park et al., } \\
1994\end{array}$ \\
\hline
\end{tabular}

Table 1. Putative GSK3 substrates

\section{6 CBP}

CBP, or the CREB (cyclic-AMP-responsive element binding protein) binding protein, has initially been identified in 1993 through its ability to interact with the phosphorylated form of CREB (Chrivia et al., 1993). CBP is encoded by a gene spanning approximately $190 \mathrm{~kb}$ of chromosome 16p13.3 (Giles et al., 1998). CBP codes for an 8.7-kb mRNA (7.3 kb of which is coding sequence) that when translated, yields a protein of 2440 and 2441 amino acid (aa) residues in humans and mice, respectively (Chrivia et al., 1993). The protein resolves to a band of approximately $265 \mathrm{kDa}$ on a sodium dodecyl sulphate (SDS) polyacrylamide gel and comprises several different domains: an N-terminal nuclear receptor binding domain, three cysteine-histidine-rich domains, a bromodomain, two zinc 
finger motifs, and a histone acetyltransferase (HAT) domain (Fig. 4). As a result of the many identified protein-interacting domains, CBP has been proposed to function as a molecular scaffold and signal integrator through its association with at least 45 different molecules including transcription factors, signaling molecules, and nuclear hormone receptors (Giles et al., 1998). CBP is an evolutionarily highly conserved protein sharing $95 \%$ identity between human and mouse. Orthologs have been identified in a number of different organisms including Drosophila melanogaster (3190 aa), Caenorhabditis elegans (putative protein of 1670 aa), and Arabidopsis thaliana (putative protein of 2027 aa). With respect to human $\mathrm{CBP}$, the $D$. melanogaster, C. elegans, and $A$. thaliana counterparts are $69 \%$ identical or $79 \%$ similar, $51 \%$ identical or $65 \%$ similar, and $31 \%$ identical or $46 \%$ similar, respectively (Tatusova and Madden 1999). This degree of similarity suggests that CBP is likely to perform basic yet critical cellular functions. CBP also exhibits striking sequence similarity to p300 (2414 aa). Although, CBP and p300 are only 63\% identical at the amino acid level, regions of greater similarity (i.e., between $82 \%$ and $98 \%$ similar) do exist (Giles et al., 1998). Most notably the first cysteine- and histidine-rich zinc finger motif and the region encompassing the bromodomain through to the third cysteine- and histidine-rich domain (see Fig. 4) are 93\% and $86 \%$ similar, respectively. Often, CBP and p300 are considered to be sequence and functional homologs, and both have been shown to associate with the adenoviral protein, E1A. However, recent evidence has begun to identify functional differences between these two molecules. For example, CBP and p300 appear to have distinct roles in retinoic acid-induced differentiation of F9 cells (Ugai et al., 1999), while in response to ionizing radiation p300, and not CBP, appears to be involved in the induction of apoptosis (Yuan et al., 1999).

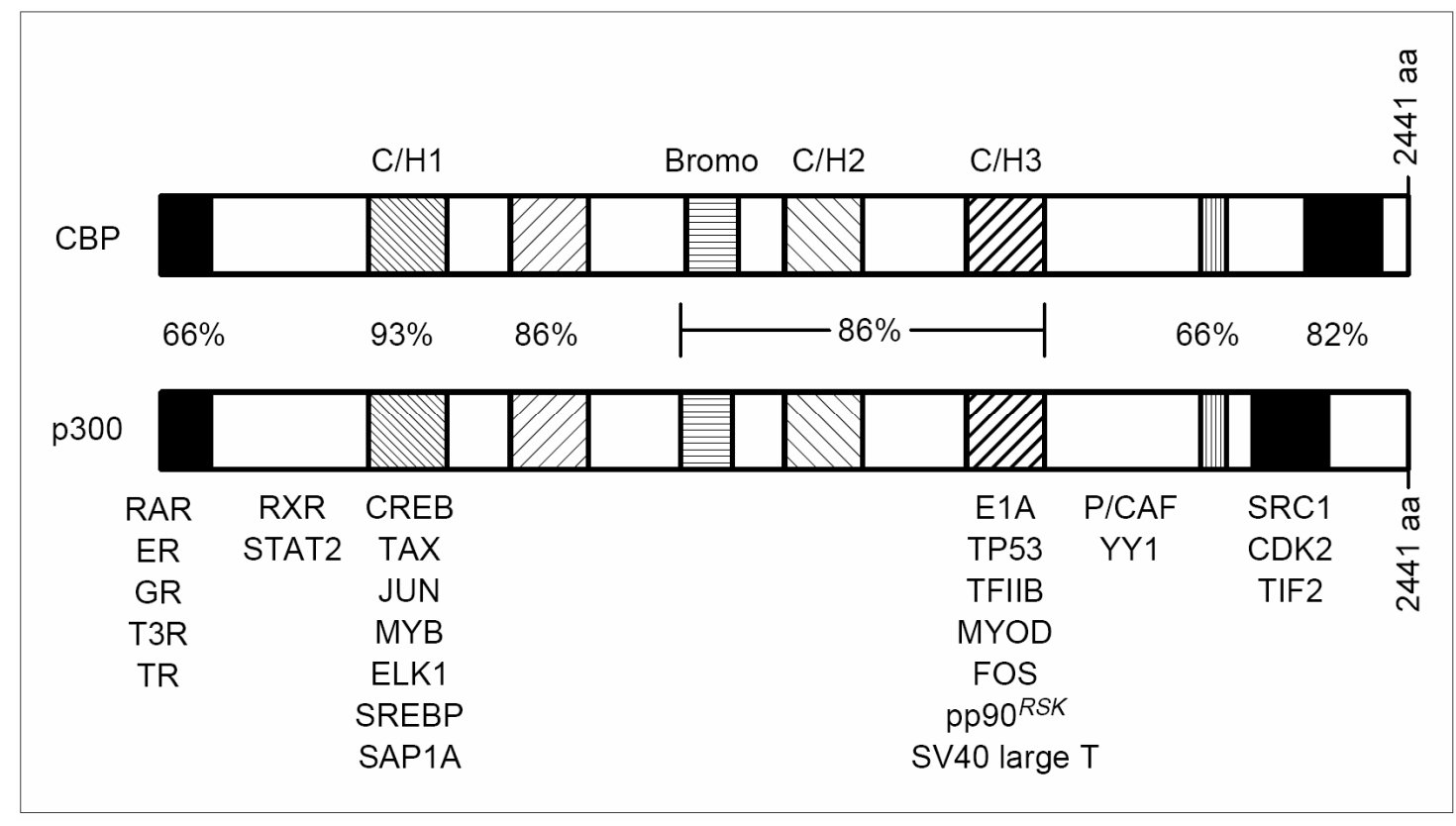


Fig. 4. Alignment of human CBP and p300 proteins (Goodman and Smolik, 2000)

Shaded regions indicate areas of high homology, often corresponding to conserved protein interaction domains (listed below p300). Percentages refer to amino acid (aa) identity between proteins. A partial list of CBP-interacting proteins has been included, and the bars indicate interaction regions. $\mathrm{C} / \mathrm{H} 1-\mathrm{C} / \mathrm{H} 3$, cysteine-histidine-rich zinc finger motifs; Bromo, bromodomain.

Evidence suggests that CBP/p300 levels are limiting in cells, but how (or whether) this situation contributes to inhibitory crosstalk between transcriptional pathways remains unresolved. Finally, the ability of CBP/p300 to serve as mediators of both cell proliferation and growth arrest pathways remains a paradox. Nonetheless, the absolute requirement for these coactivators in the actions of many (or even most) transcription factors indicates that they will continue to provide a fruitful target for studies aimed at understanding the complex interactions that underlie the control of cell growth and differentiation (Goodman and Smolik, 2000).

Recently, it has been shown that CBP transcriptional activity at the glucagon gene promoter is inhibited by insulin and induced by GSK3 $\beta$ (Dimopoulos N., PhD Thesis, 2003). Thus, this provides the hypothesis, that insulin-induced inhibition of glucagon gene transcription might be triggered through CBP, acting as a direct target for GSK3 $\beta$.

\section{7 Aim of the study}

The aim of the present work was to investigate GSK3 $\beta$ phosphorylation sites within the Cterminal part of CBP in vitro and to examine their functional significance for the stimulation by GSK3 $\beta$ and the inhibition by insulin of glucagon gene transcription in transient transfection experiments using the glucagon-producing cell line InR1G9. 


\section{MATERIALS and METHODS}

\section{1 MATERIALS}

\section{1.1 Instruments}

\author{
Autoclave \\ Balances \\ Cell culture hood \\ Cell culture incubator \\ Centrifuges
}
Electrophoresis chamber (DNA)
Electrophoresis chamber (protein)
Electrophoresis power supply
Fluorimeter
Freezer $\left(-20^{\circ} \mathrm{C}\right)$
Freezer $\left(-80^{\circ} \mathrm{C}\right)$
Gel Dryer

Handheld Contamination Monitor

Heat block

Incubator for bacterial culture

Light microscope

Luminometer

Mass-Spectrometer

Microwave oven

PCR-Machine

$\mathrm{pH}$ meter

Phosphoimager

Pipettes

Pipettus akku

Refrigerator

Rotator
Bioclav, Schütt Labortechnik, Göttingen

Sartorius AG, Göttingen

Lamin Air, HB 2448, Heraeus, Hanau

Steri-cult 200, Labotect, Göttingen

1)Megafuge-Biofuge, Heraeus $\mathrm{GmbH}$, Hanau

2)Eppendorf 5417R, Eppendorf $\mathrm{GmbH}$

Hamburg

3)Beckman J2-HS, Beckman $\mathrm{GmbH}$, Krefeld

4)Ultracentrifuge L8-70M Beckman ${ }^{\circledR}$,

Beckman, Krefeld

Roth, Karlsruhe

Mighty Small SE 250/SE 260, Hoefer, San

Francisco, USA

Biometra, Göttingen

Fusion $^{\mathrm{TM}}$, Packard, Switzerland

Bosch, Germany

Sanyo, Japan

Dry Gel SR, SE 1160, Hoefer Scientific Instruments, San Francisco, USA

Berthold LB122, Berthold Technologies, Bad Wildbad

W. Krannich $\mathrm{GmbH}$, Göttingen

Heraeus $\mathrm{GmbH}$, Hanau

Nikon, Japan

AutoLumat LB 953, Berthold Technologies, Bad Wildbad

Voyager 4122, Applied Biosystems,

Darmstadt

Bauknecht, Germany

Biometra Trio-Thermoblock, Göttingen

pH 523, Schütt Labortechnik, Göttingen

Raytest, Fujifilm BAS-1500, Stuttgart

Gilson, France

Hirschmann Laborgeräte, Göttingen

Liebherr, Ochsenhausen

TRM-V, IDL GmbH, Nidderau-Heldenbergen 
Rotors

Scanner

Scintillation counter

Sequencer

Shaker

Sonicator

Speedvac

Spectrophotometer

Thermomixer

Transilluminator

Video Copy Processor

Vortex

Waterbaths

\subsection{Consumables}

Cell culture plastic equipment

$E C L$ - $X$ ray films

Falcon tubes

Filters

Membrane

Pasteur pipettes

Pipette tips

Plastic tubes

PCR tubes

Spectrophotometer cuvettes

Ultracentrifuge tubes

Whatman paper P81
Beckman Rotors JA-20/JA17/JA14, Beckman $\mathrm{GmbH}$, Krefeld

HP ScanJet 3800

Beckman LS 1801, Beckman, Krefeld

Genetic Analyzer 3100, Applied Biosystems,

Darmstadt

Rocking Platform, Biometra, Göttingen

Sonifier, Cell Disruptor B-15, Branson,

Geneva, Switzerland

Heto VR-I, Hetovac

Shimadzu UV-160, Duisburg

Eppendorf, Hamburg

UV Kontaktlampe Chroma 42, 366nm, Schütt Labortechnik, Göttingen

Mitsubishi, Molekulare Trenntechnik, Wiesloch Janke \& Kunkel IKA-Labortechnik, Göttingen W. Krannich $\mathrm{GmbH}$, Göttingen
Becton Dickinson, France

Amersham Biosciences, UK

Cell star ${ }^{\circledR}$, Greiner Bio-one, Solingen

Sartorius, Göttingen

Hybond $^{\mathrm{TM}} \mathrm{ECL}^{\mathrm{TM}}$ Nitrocellulose membrane,

GE Healthcare, UK

Brand, Wertheim/Main

Sarstedt, Nümbrecht

Sarstedt, Nümbrecht

Eppendorf, Hamburg

Sarstedt, Nümbrecht

Beckman $\mathrm{GmbH}$, Krefeld

Whatman, Maidstone, UK

\section{1. 3 Antibiotics}

Ampicillin

Chloramphenicol
Applichem, Darmstadt

Sigma, Taufkirchen 


\subsubsection{General Chemicals}

Acrylamide

Agarose

Ampicillin

APS

Aprotinin

Aqua ad injectabilia

ATP

Bis-acrylamide

Bromophenol blue

BSA

DEAE-Dextran

DMSO

DTT

EDTA

EGTA

Ethanol

Ethidium bromide

Glucose

Glutathione reduced form

Glutathione agarose beads

Glycerol

Glycylglycine

IPTG

Isopropanol

Leupeptin

Luciferin

Lysozyme

PEG

Pepstatin

PMSF

Potassium chloride

SDS

Sodium chloride

Sucrose

TEMED
Serva, Heidelberg

Invitrogen, UK

Applichem, Darmstadt

Sigma, Taufkirchen

Sigma, Taufkirchen

Braun, Melsungen

Sigma, Taufkirchen

Serva, Heidelberg

Sigma, Taufkirchen

Applichem, Darmstadt

Pharmacia, UK

Sigma, Taufkirchen

Applichem, Darmstadt

Applichem, Darmstadt

Applichem, Darmstadt

Applichem, Darmstadt

Sigma, Taufkirchen

Applichem, Darmstadt

Sigma, Taufkirchen

Sigma, Taufkirchen

Applichem, Darmstadt

Applichem, Darmstadt

Applichem, Darmstadt

Applichem, Darmstadt

Sigma, Taufkirchen

Promega, Mannheim

Applichem, Darmstadt

Applichem, Darmstadt

Sigma, Taufkirchen

Applichem, Darmstadt

Applichem, Darmstadt

Applichem, Darmstadt

Applichem, Darmstadt

Applichem, Darmstadt

Applichem, Darmstadt 
Tris

Triton X-100

Tween 20

- Radiochemicals

Y- ${ }^{32} \mathrm{P}-\mathrm{ATP}(250 \mu \mathrm{Ci}, 3000 \mathrm{Ci} / \mathrm{mmol})$

$\alpha{ }^{32} \mathrm{P}-\mathrm{dCTP}(3000 \mathrm{Ci} / \mathrm{mmol})$
Applichem, Darmstadt

Sigma, Taufkirchen

Applichem, Darmstadt

GE Healthcare, UK

GE Healthcare, UK

\subsubsection{Kits}

Agarose Gel Extraction Kit

DNA Midi-Prep Kit

BigDye Terminator Ready Reaction

Cycle Sequencing Kit

Labeled nucleic acids purification Kit
Easy Pure, Biozym, Oldendorf

Promega, Mannheim

Applied Bioscience, Darmstadt

Quick Spin, Roche Applied Science, Mannheim

\section{1. 6 Bacterial culture materials}

Select-agar

Select-peptone

Select-yeast extract

Petri-dishes $(10 \mathrm{~cm})$
Invitrogen, Karlsruhe

Applichem, Darmstadt

Applichem, Darmstadt

Greiner, Frickenhausen

\section{$\underline{\text { LB (Luria - Bertani) medium : }}$}

Select peptone

Select yeast extract

$\mathrm{NaCl}$

$\mathrm{ddH}_{2} \mathrm{O}$
$10 \mathrm{~g}$

$5 \mathrm{~g}$

$10 \mathrm{~g}$

ad $1 \mathrm{~L}$

For preparing agar plates agar $(1.5 \%, w / v)$ was added to LB medium and medium was autoclaved for $20 \mathrm{~min}$ at $120^{\circ} \mathrm{C}$ at $15 \mathrm{psi}$. The solution was cooled and ampicillin was added to a final concentration $50 \mu \mathrm{g} / \mathrm{ml}$. 


\subsubsection{Eukaryotic cell line}

The following cell line was used: a glucagon-producing Golden Hamster pancreatic tumor cell line, InR1G9 (a-cell phenotype) (Takaki et al., 1986).

\section{1. 8 Eukaryotic cell culture materials}

Penicillin $(10,000 \mathrm{U} / \mathrm{ml})$ - streptomycin

$(10,000 \mu \mathrm{g} / \mathrm{ml})$ in solution

RPMI 1640 medium

FCS

Trypsin-EDTA, unit $100 \mathrm{~mL}$

Falcon dishes
GIBCO-BRL, Karlsruhe

GIBCO-BRL, Karlsruhe

GIBCO-BRL, Karlsruhe

GIBCO-BRL, Karlsruhe

Becton Dickinson, Franklin Lakes, NJ, USA

Media for eukaryotic InR1G9 cells:

RPMI medium ( $1 \mathrm{~L}$ ): RPMI 1640 medium powder, $\mathrm{NaHCO}_{3} 2 \mathrm{~g}$, volume adjusted to $1 \mathrm{~L}$ with distilled water and filter sterilised

Complete medium :

RPMI medium ad $500 \mathrm{ml}$

Fetal bovine serum $50 \mathrm{ml}$

Penicillin-streptomycin solution $\quad 5 \quad \mathrm{ml}$

BSA containing medium :

RPMI medium

ad $500 \mathrm{ml}$

BSA

$2.5 \mathrm{~g}$

Penicillin-streptomycin solution

$5 \mathrm{ml}$

Sterilize through filter $0.2 \mu \mathrm{m}$

Sartorius, Göttingen

\section{1. 9 General buffers and media}

Routinely used buffers and media were prepared according to 'Molecular Cloning' laboratoy manual (Sambrook et al., 1989) : 
$1 \times$ PBS :

$\mathrm{NaCl}$

$140 \mathrm{mM}$

$\mathrm{KCl}$

$2.5 \mathrm{mM}$

$\mathrm{Na}_{2} \mathrm{HPO}_{4}$

$8.1 \mathrm{mM}$

$\mathrm{KH}_{2} \mathrm{PO}_{4}$

$1.5 \mathrm{mM}$

$\mathrm{pH}$ adjusted to 7.4

$50 \times$ TAE :

Tris

$2 \mathrm{M}$

EDTA

$50 \mathrm{mM}$

Acetic acid, pH 8.5

$4 \%$

$1 \times$ TE :

Tris $\mathrm{pH} 8.0$

$10 \mathrm{mM}$

EDTA pH 8.0

$1 \mathrm{mM}$

Stock solutions:

Ampicillin

$50 \mathrm{mg} / \mathrm{ml}$ (in water)

DTT

$1 \mathrm{M}$ (in water)

ATP

$200 \mu \mathrm{M}$ (in water)

PMSF

$250 \mu \mathrm{M}$ (in ethanol)

If not otherwise mentioned, organic liquid buffers and reagents were purchased from Applichem, Darmstadt.

2. 1. 10 Reporter gene plasmids, constructs and the oligonucleotides used in this study

All constructs were sequenced in order to confirm the identity and the orientation of the inserts.

\begin{tabular}{|l|l|}
\hline Reporter gene construct & Reference \\
\hline-350 GluLuc & Schwaninger et al., 1993 \\
\hline-350 (mutG1/G3)GluLuc & Grzeskowiak et al., 2000 \\
\hline $5 \times$ Gal4(E1B)Luc & Krüger et al., 1997 \\
\hline
\end{tabular}

Table 2. Reporter gene plasmids, used in this study 
The plasmid pCMV-GFP-tpz was purchased from Canberra-Packard, Dreieich, Germany.

\begin{tabular}{|c|c|}
\hline Construct & Description \\
\hline 1) GST-CBP(2040-2170) & $\begin{array}{l}\text { Amino acids } 2040 \text { to } 2170 \text { of CBP } \\
\text { with N-terminally fused GST tag }\end{array}$ \\
\hline 2) GST-CBP(2160-2305) & $\begin{array}{l}\text { Amino acids } 2160 \text { to } 2305 \text { of CBP } \\
\text { with N-terminally fused GST tag }\end{array}$ \\
\hline 3) GST-CBP(2300-2441) & $\begin{array}{l}\text { Amino acids } 2300 \text { to } 2441 \text { of CBP } \\
\text { with N-terminally fused GST tag }\end{array}$ \\
\hline 4) $p c D N A 3-C B P(2040-2170) \mathrm{HA}$ & $\begin{array}{l}\text { Amino acids } 2040 \text { to } 2170 \text { of CBP } \\
\text { with C-terminally fused HA tag }\end{array}$ \\
\hline 5) $\operatorname{pcDNA3-CBP(2160-2305)HA~}$ & $\begin{array}{l}\text { Amino acids } 2160 \text { to } 2305 \text { of CBP } \\
\text { with C-terminally fused HA tag }\end{array}$ \\
\hline 6) $\operatorname{pcDNA3-CBP(2300-2441)HA}$ & $\begin{array}{l}\text { Amino acids } 2300 \text { to } 2441 \text { of CBP } \\
\text { with C-terminally fused HA tag }\end{array}$ \\
\hline 7) GST-CBP(2300-2441)S2420A & $\begin{array}{l}\text { Amino acids } 2040 \text { to } 2170 \text { of } C B P \text {; } \\
\text { serine- } 2420 \text { mutated to alanine }\end{array}$ \\
\hline 8) GST-CBP(2300-2441)S2424A & $\begin{array}{l}\text { Amino acids } 2160 \text { to } 2305 \text { of CBP; } \\
\text { serine- } 2424 \text { mutated to alanine }\end{array}$ \\
\hline 9) GST-CBP(2300-2441) S2420A/S2424A & $\begin{array}{l}\text { Amino acids } 2300 \text { to } 2441 \text { of CBP; } \\
\text { serine-2420 mutated to alanine } \\
\text { and serine-2424 mutated to } \\
\text { alanine }\end{array}$ \\
\hline 10) Gal4-CBP(2040-2441) & $\begin{array}{l}\text { N-terminally fused DNA-binding } \\
\text { domain GAL4 (amino acids 1-147) }\end{array}$ \\
\hline 11) Gal4-CBP(2040-2441)S2420A & $\begin{array}{l}\text { N-terminally fused DNA-binding } \\
\text { domain GAL4 (amino acids 1-147) }\end{array}$ \\
\hline 12) Gal4-CBP(2040-2441) S2424A & $\begin{array}{l}\text { N-terminally fused DNA-binding } \\
\text { domain GAL4 (amino acids 1-147) }\end{array}$ \\
\hline 13) Gal4-CBP(2040-2441)S2420A/S2424A & $\begin{array}{l}\mathrm{N} \text {-terminally fused DNA-binding } \\
\text { domain GAL4 (amino acids 1-147) }\end{array}$ \\
\hline 14) GSK3ßwt & $\begin{array}{l}\text { Plasmid, encoding GSK3 } \beta \text { wild } \\
\text { type }\end{array}$ \\
\hline 15) GSK3R85A & $\begin{array}{l}\text { Plasmid, encoding GSK3 } \beta \text { kinase } \\
\text { "dead" mutant }\end{array}$ \\
\hline
\end{tabular}

Table 3. List of the constructs, used in this study

Constructs 1-3 and 7-9 were used for GST-CBP fusion protein overexpression in bacteria and purification as described in 2. 2. 2. Constructs 1-3 were prepared by digestion of the PCR-product with BamHI and ligated into the BamHI site of the vector pGEX2T. 
Mutations, where indicated were introduced by site-directed mutagenesis as described in 2. 2. 1. 12. GST-CBP(2300-2441) was taken as a template.

Constructs 4-6 were prepared by introducing an HA-tag by PCR and further subcloning into the EcoRV/Xbal site of pcDNA3 vector. These constructs were used for in vivo experiments (see 2. 2. $6-2.2 .7$ for details).

Constructs 10-15 were used for transient transfections (2. 2. 11. 2); mutations in constructs 11-13 were introduced by site-directed PCR mutagenesis (2. 2. 1. 12) talking Gal4-CBP(2040-2441) as a template.

GSK3ßwt and GSK3R85A were subcloned into the CMV-driven eukaryotic expression vector pBAT14 (research group Prof. W. Knepel).

\begin{tabular}{|c|c|c|}
\hline GST-CBP-2040-5' & $5^{\prime}$ - CGGGATCCGTAATGTCCATGCAGG- $3^{\prime}$ & \\
\hline GST-CBP-2170-3' & 5' -GCGGATCCTTGTCCCTGGGGATTC- $3^{\prime}$ & \\
\hline GST-CBP $-2160-5^{\prime}$ & $5^{\prime}$ - CGGGATCCCCAGCAATGGGAGGCG - $3^{\prime}$ & \\
\hline GST-CBP-2305-3' & $5^{\prime}$-GGCGGATCCCCCAATTTGTTGCTTC- $3^{\prime}$ & \\
\hline GST-CBP $-2300-5^{\prime}$ & $5^{\prime}$ - CGGGATCCATGAAGCAACAAATTGG - 3' & \\
\hline GST-CBP - $2441-3$ & $5^{\prime}$ - GCGGATCCCAAACCCTCCACAAAC- $3^{\prime}$ & \\
\hline S2420Afor & $5^{\prime}$-GCGCACTGGCCAGTGAACTG- 3' & $\begin{array}{l}\text { CBP } \\
\text { Mutagenesis }\end{array}$ \\
\hline S2420Arev & $5^{\prime}$ - TTCACTGGCCAGTGCGCTCC- $3^{\prime}$ & $\begin{array}{l}\text { CBP } \\
\text { Mutagenesis }\end{array}$ \\
\hline S2424Afor & $5^{\prime}$ - CAGTGAACTGGCCCTGGTTGG - 3' & $\begin{array}{l}\text { CBP } \\
\text { Mutagenesis }\end{array}$ \\
\hline S2424Arev & $5^{\prime}$ - CCAACCAGGGCCAGTTCACTG - $3^{\prime}$ & $\begin{array}{l}\text { CBP } \\
\text { Mutagenesis }\end{array}$ \\
\hline SS2 024 AAfor & $5^{\prime}$ - GCGCACTGGCCAGTGAACTGGCCCTGGT - 3' & $\begin{array}{l}\text { CBP } \\
\text { Mutagenesis }\end{array}$ \\
\hline SS2 024 AArev & $5^{\prime}$ - ACCAGGGCCAGTTCACTGGCCAGTGCGC- $3^{\prime}$ & $\begin{array}{l}\text { CBP } \\
\text { Mutagenesis }\end{array}$ \\
\hline pcdna $3-2040-5^{\prime}$ & $\begin{array}{c}5^{\prime}- \\
\text { TCGGATATCATGGTAATGTCCATGCAGGCCCA-3' }\end{array}$ & \\
\hline pcdna $3-2170-3^{\prime}$ & $\begin{array}{c}5^{\prime}- \\
\text { TACTCTAGATTAAGCGTAATCCGGAACATCGTATG } \\
\text { GGTATTGTCCCTGGGGATTCAG }-3^{\prime}\end{array}$ & \\
\hline pcdna $3-2160-5^{\prime}$ & $\begin{array}{c}5^{\prime}- \\
\text { TCGGATATCATGCCAGCAATGGGAGGCCTGAAT - } \\
3^{\prime} \\
\end{array}$ & \\
\hline pcdna $3-2305-3^{\prime}$ & $\begin{array}{c}5^{\prime}- \\
\text { TACTCTAGATTAAGCGTAATCCGGAACATCGTATG } \\
\text { GGTACCCAATTTGTTGCTTCATCTGCT }-3^{\prime}\end{array}$ & \\
\hline pcdna $3-2300-5^{\prime}$ & $\begin{array}{c}5^{\prime}- \\
\text { TCGGATATCATGATGAAGCAACAAATTGGGTCA- } \\
3^{\prime} \\
\end{array}$ & \\
\hline pcdna $3-2441-3^{\prime}$ & $\begin{array}{c}5^{\prime}- \\
\text { TACTCTAGATTAAGCGTAATCCGGAACATCGTATG } \\
\text { GGTACAAACCCTCCACAAACTTTTCT-3' }\end{array}$ & \\
\hline EMSA_GAL4_f & 5' - GATCCGGAGTACTGTCCTCCG- 3' & EMSA \\
\hline EMSA_GAL4_r & $5^{\prime}$ - GATCCGGAGGACAGTACTCCG- 3' & EMSA \\
\hline
\end{tabular}




\begin{tabular}{|l|c|c|}
\hline pcDNA3-CMV-for & 5'-CAGAGCTGTTTAGTCAACC-3' & Sequencing \\
\hline pGEX5' -seq & 5'-GGGCTGGCAAGCCACGTTTGGTG-3' & Sequencing \\
\hline pGEX3'-seq & 5'-CCGGGAGCTGCATGTGTCAGAGG-3' & Sequencing \\
\hline
\end{tabular}

Table 4. Oligonucleotides, used in this study

Recognition sequences of restriction enzymes are highlated in black.

* These primers were used for subcloning of the CBP(2040-2170), CBP(2160-2305), CBP (2300-2441) into the pGEX2T vector using BamHI.

** These primers were used in order to introduce the HA-tag at the C-terminus of CBP (2040-2170), CBP(2160-2305), CBP(2300-2441) and subcloning into the pcDNA3 vector using EcoRV and Xbal.

\section{1. 11 Antibodies, proteins, molecular weight standards and enzymes}

Primary antibodies :

\begin{tabular}{|c|c|c|c|c|}
\hline Antibody & Manufacturer & $\begin{array}{c}\text { Blocking } \\
\text { Buffer }\end{array}$ & Dilution & Application \\
\hline Anti-HA & Sigma & Milk/PBS-T & $1: 300$ & IP \\
\hline Anti-HA & Sigma & Milk/PBS-T & $1: 1000$ & WB \\
\hline Antiphosposerine/threonine & $\begin{array}{c}\text { BD Transduction } \\
\text { Laboratories }\end{array}$ & BSA/TBS-T & $1: 2500$ & WB \\
\hline Antiphosphothreonine & Sigma & BSA/TBS-T & $1: 500$ & WB \\
\hline Antiphosphoserine & $\begin{array}{c}\text { Zymed } \\
\text { Laboratories }\end{array}$ & BSA/TBS-T & $1: 500$ & WB \\
\hline AntiphosphoCREB(S133P) & Cell Signalling & Milk/PBS-T & $1: 1000$ & WB \\
\hline
\end{tabular}


Secondary antibodies:

\begin{tabular}{|c|c|c|c|c|}
\hline Antibody & Manufacturer & $\begin{array}{c}\text { Blocking } \\
\text { Buffer }\end{array}$ & Dilution & Application \\
\hline $\begin{array}{c}\text { Peroxidase labelled anti- } \\
\text { mouse }\end{array}$ & $\begin{array}{c}\text { Amersham } \\
\text { Bioscience }\end{array}$ & $\begin{array}{c}\text { Same as for } \\
\text { primary a/b }\end{array}$ & $1: 10000$ & WB \\
\hline $\begin{array}{c}\text { Peroxidase labelled anti- } \\
\text { rabbit }\end{array}$ & $\begin{array}{c}\text { Amersham } \\
\text { Bioscience }\end{array}$ & $\begin{array}{c}\text { Same as for } \\
\text { primary a/b }\end{array}$ & $1: 10000$ & WB \\
\hline
\end{tabular}

Table 5. List of antibodies, used in this study

Protein:

- GSK3ß, recombinant, active, New England Biolabs, Lake Placid, NY, USA

Protein marker:

- Page Ruler, MBI Fermentas, St.Leon-Rot, Germany.

- SDS 7B, SDS molecular weight standard mixture, Sigma, Taufkirchen

DNA marker:

- Gene ruler $1 \mathrm{~Kb}$ DNA ladder, MBI Fermentas, St.Leon-Rot, Germany.

All other enzymes used including restriction endonucleases, T4-DNA ligase, alkaline phosphatase were purchased from MBI Fermentas, St.Leon-Rot, Germany. 


\section{2 METHODS}

\section{2. 1 Standard methods of molecular cloning}

\section{2. 1. 1 Preparation of competent Escherichia coli bacteria}

Competent bacteria were produced by modification of the cell wall, which facilitates DNA uptake. $100 \mathrm{ml}$ of LB medium was inoculated with a single colony of Escherichia coli strain $\mathrm{DH} 5 \alpha$ and culture was grown at $37^{\circ} \mathrm{C}, 200 \mathrm{rpm}$, until OD600 reached 0.6. Bacteria were centrifuged for $10 \mathrm{~min}$ at $4^{\circ} \mathrm{C}, 3,000 \mathrm{rpm}$, and the pellet was resuspended in $50 \mathrm{ml}$ of sterile $50 \mathrm{mM} \mathrm{CaCl} 2$ at $4{ }^{\circ} \mathrm{C}$ and incubated on ice for $30 \mathrm{~min}$. The suspension was centrifuged for $10 \mathrm{~min}$ at $4^{\circ} \mathrm{C} 3,000 \mathrm{rpm}$ and the pellet was resuspended in $10 \mathrm{ml}$ of sterile $50 \mathrm{mM} \mathrm{CaCl}{ }_{2}$ with $15 \%$ glycerol. The mixture was dispensed into aliquots of $100 \mu \mathrm{l}$ and stored at $-80^{\circ} \mathrm{C}$.

\section{2. 1. 2 LB-ampicillin agar dishes}

Bactoagar was added to the LB medium to a final concentration of $1.5 \%$, followed by autoclaving. Afterward, the medium was let cool down to $55^{\circ} \mathrm{C}$ and ampicillin was added to a final concentration of $50 \mu \mathrm{g} / \mathrm{ml}$. This medium was poured into $10 \mathrm{~cm}$ sterile Petridishes and left undisturbed for about 30 minutes to solidify. LB-Agar dishes were stored in the dark at $4^{\circ} \mathrm{C}$.

\section{2. 1. 3 Transformation of competent bacteria}

Transformation was carried out by gentle mixing and incubating a $30 \mu \mathrm{l}$ aliquot of competent cells with 5-10 ng of plasmid DNA for $30 \mathrm{~min}$ on ice. After the incubation the mixture was further subjected to "heat shock", $45 \mathrm{sec}$ at $42^{\circ} \mathrm{C}$. The cells were then placed on ice for 2-3 min and incubated with $0.1 \mathrm{ml}$ LB medium without antibiotics at $37^{\circ} \mathrm{C}$ for 20 30 min under constant agitation, $225 \mathrm{rpm}$, to recover and to express the plasmid genes. The whole transformation mixture was then used and plated on LB agar plates containing ampicillin. The plates were incubated overnight at $37^{\circ} \mathrm{C}$. 


\section{2. 1. 4 Mini preparation of plasmid DNA}

A modified alkaline lysis method was used to purify plasmid DNA. A single colony was inoculated into $5 \mathrm{ml}$ of LB medium plus ampicillin and grown overnight at $37^{\circ} \mathrm{C}, 220 \mathrm{rpm}$. Next day, $1.5 \mathrm{ml}$ of culture was centrifuged at $4^{\circ} \mathrm{C}, 6,000 \mathrm{rpm}$ for $5 \mathrm{~min}$ (Eppendorf $5415 \mathrm{C})$. The pellet was resuspended in $100 \mu \mathrm{l}$ of Solution I. Next, $200 \mu \mathrm{l}$ of Solution II was added plus $200 \mu \mathrm{l}$ of chloroform and the tube was carefully inverted to mix. After $1 \mathrm{~min}$ of lysis, $150 \mu \mathrm{l}$ of ice cold Solution III was added and the mixture was vortexed shortly.

The mixture was centrifuged at RT for $2 \mathrm{~min}, 14,000 \mathrm{rpm}$. The upper phase (approximately $360 \mu \mathrm{l}$ ) was transferred into a fresh Eppendorf tube and one volume of $100 \%$ isopropanol was added. The mixture was incubated $30 \mathrm{~min}$ at $-20{ }^{\circ} \mathrm{C}$, centrifuged for $5 \mathrm{~min}$ at $4^{\circ} \mathrm{C}, 14,000 \mathrm{rpm}$, and the supernatant was discarded.

The pellet was washed twice with $80 \%$ ethanol and then dried under vacuum. Dry pellet was redissolved in $20 \mathrm{ml}$ of RNase I solution $(0.1 \mu \mathrm{g}$ in $1 \mathrm{ml}$ of TE buffer) and incubated at $37^{\circ} \mathrm{C}$ for $1 \mathrm{~h}$ (RNA digestion). An aliquot of the plasmid DNA was subjected to the restriction enzyme digest.

Solution I: $50 \mathrm{mM}$ glucose, $10 \mathrm{mM}$ EDTA, $25 \mathrm{mM}$ Tris $\mathrm{pH} 8.0$

Solution II: $0.2 \mathrm{~N} \mathrm{NaOH}, 1 \%$ SDS

Solution III : $29.4 \mathrm{~g} \mathrm{KAc}, 5 \mathrm{ml} \mathrm{CH} \mathrm{CHOH}_{3} \mathrm{Ond}$ water to $100 \mathrm{ml}$

\section{2. 1. 5 Maxi preparation of plasmid DNA}

Large amounts of plasmid DNA (1-2 mg) were produced using preparative ultracentrifugation of bacterial lysate in a $\mathrm{CsCl}$ gradient as follows:

$15 \mathrm{ml}$ of LB medium, plus ampicillin at final concentration $50 \mu \mathrm{g} / \mathrm{ml}$, was inoculated with a single colony. The culture was grown overnight in a rotary shaker $225 \mathrm{rpm}$ at $37^{\circ} \mathrm{C}$. Next day, 1 liter of LB medium plus amp was inoculated with the preculture and grown at $37^{\circ} \mathrm{C}$, until the OD600 reached 0.8-1.0. Chloramphenicol was added to get the final concentration of $200 \mathrm{mg} / \mathrm{L}$ and incubated for $12 \mathrm{~h}$. The $1 \mathrm{~L}$ culture was centrifuged at $10,000 \mathrm{rpm}$ (Beckman JA-14 Rotor) for $15 \mathrm{~min}$ at $4^{\circ} \mathrm{C}$.

The pellet was resuspended in $45 \mathrm{ml}$ ice cold STE and $3 \mathrm{ml}$ of lysozyme was added (60 $\mathrm{mg} / \mathrm{ml}$ in STE). After incubation for $20 \mathrm{~min}$ on ice, $3.6 \mathrm{ml}$ of $0.5 \mathrm{M}$ EDTA was added and the mixture was incubated for $5 \mathrm{~min}$ on ice. Then, $28.8 \mathrm{ml}$ of Triton-mix was added. The mixture was incubated on ice for 30 min (shaking every $5 \mathrm{~min}$ ). 
The mixture was centrifuged for $1 \mathrm{~h}$ at 16,000 rpm (Beckman JA-20 Rotor) at $4^{\circ} \mathrm{C}$. Next, $40 \mathrm{ml}$ of $30 \%$ PEG was added to the supernatant (30\% PEG $6000,1.5 \mathrm{M} \mathrm{NaCl}$ ) and the mixture was incubated for $1 \mathrm{~h}$ on ice. The mixture was centrifuged for $10 \mathrm{~min}$ at 10,000 rpm (Beckman JA-14 Rotor) at $4^{\circ} \mathrm{C}$ and the supernatant was discarded.

The pellet was resuspended in $10 \mathrm{ml}$ of TNE buffer and $10.9 \mathrm{~g}$ of $\mathrm{CsCl}$ plus $150 \mu \mathrm{l}$ of ethidium bromide $(10 \mathrm{mg} / \mathrm{ml})$ were added. The solution was pipetted into an ultracentrifuge tube. The difference between the tubes weight should not be more than $0.05 \mathrm{~g}$. The tubes were centrifuged for $20 \mathrm{~h}$ at $60,000 \mathrm{rpm}$ at $20^{\circ} \mathrm{C}$ in a Beckman Ultracentrifuge L5-65, 70Ti-Rotor.

The band containing plasmid DNA was recovered with syringe and needle. The ethidium bromide was extracted from the DNA solution with equal volumes of isoamylalcohol. Extraction procedure was repeated 4-5 timed, upper phase, containing ethidium bromide, was carefully discarded and the fresh isoamylalcohol was added until the solution was colorless.

The clear solution was put into dialysis tubings and dialysed against $1 \mathrm{~L}$ TE per construct (10 $\mathrm{mM}$ Tris $\mathrm{pH} 8.0,1 \mathrm{mM}$ EDTA pH 8.0) twice at $4^{\circ} \mathrm{C}$ to remove $\mathrm{CsCl}$.

The concentration and purity of the plasmid DNA was estimated spectrophotometrically (OD260, OD280 in Shimadzu Spectrophotometer).

\section{$\underline{\text { Lysozyme }}$}

$\begin{array}{ll} & \text { For } 1 \mathrm{ml} \\ \text { Lysozyme } & 60 \mathrm{mg} \\ \text { STE } & 1 \mathrm{ml}\end{array}$

\section{$\underline{\text { STE }}$}

For $100 \mathrm{ml}$

Saccharose $(25 \%) \quad 25 \mathrm{~g}$

EDTA $(1 \mathrm{mM}) \quad 0.2 \mathrm{ml} / 0.5 \mathrm{M}$

Tris- $\mathrm{HCl} \mathrm{pH} 8.0(50 \mathrm{mM}) \quad 5 \mathrm{ml} / 1 \mathrm{M}$

\section{$\underline{\text { Triton-Mix }}$}

$\begin{array}{ll} & \text { For } 100 \mathrm{ml} \\ \text { Triton X-100 (0.1\%) } & 0.1 \mathrm{ml} \\ \text { EDTA (60 mM) } & 12 \mathrm{ml} / 0.5 \mathrm{M} \\ \text { Tris- HCl pH } 8.0(50 \mathrm{mM}) & 5 \mathrm{ml} / 1 \mathrm{M}\end{array}$


$30 \%$ PEG

$\begin{array}{ll} & \text { For } 100 \mathrm{ml} \\ \text { PEG } 6000(30 \%) & 30 \mathrm{~g} \\ \mathrm{NaCl}(1.5 \mathrm{M}) & 30 \mathrm{ml} / 5 \mathrm{M}\end{array}$

$\underline{\text { TNE-buffer }}$

\begin{tabular}{ll}
\hline & For $100 \mathrm{ml}$ \\
Tris-HCl pH $8.0(10 \mathrm{mM}))$ & $1 \mathrm{ml} / 1 \mathrm{M}$ \\
$\mathrm{NaCl}(10 \mathrm{mM})$ & $0.2 \mathrm{ml} / 5 \mathrm{M}$ \\
EDTA $(1 \mathrm{mM})$ & $0.2 \mathrm{ml} / 0.5 \mathrm{M}$
\end{tabular}

$\underline{\mathrm{TE}}$

For $1000 \mathrm{ml}$

Tris-HCl pH $8.0(10 \mathrm{mM})) \quad 1 \mathrm{ml} / 1 \mathrm{M}$

EDTA $(1 \mathrm{mM}) \quad 2 \mathrm{ml} / 0.5 \mathrm{M}$

\section{2. 1. 6 Measurement of DNA concentration}

DNA concentration was estimated using the spectrophotometer. The concentration of DNA was calculated as follows:

for double-stranded DNA : $\quad 1.0$ OD260 unit corresponds to $50 \mu \mathrm{g} / \mathrm{ml}$

In addition to OD260, also the absorption at $280 \mathrm{~nm}$ was measured indicating protein concentration. DNA preparation which had ratio of OD260 / OD280 in the range of 1.8 2.0 were regarded as pure and protein-free.

\section{2. 1.7 Restriction enzyme analysis of DNA}

In order to characterize plasmid DNA, it was digested with restriction endonucleases. Digestions were carried out for 1-2 $\mathrm{h}$ in $10 \mu \mathrm{l}$ total volume in the optimal buffer for each enzyme, as suggested by $\mathrm{MBI}$ Fermentas. The digestion temperature was $37^{\circ} \mathrm{C}$, unless otherwise suggested. 


\section{2.1.8 Agarose gel electrophoresis}

During agarose gel electrophoresis, DNA fragments are separated according to their size e.g. the smaller a fragment, the faster it migrates. The size of a fragment is estimated by comparison to the sizes of the bands of a DNA molecular weight marker. Agarose in an appropriate concentration was dissolved in $1 \times$ TAE in a microwave oven. The solution was cooled and ethidium bromide was added at a final concentration $1 \mu \mathrm{g} / \mathrm{ml}$. Ethidium bromide is a fluorescent dye, which contains a planar group that intercalates between the stacked bases of the DNA. The fixed position of this group and its close proximity to the bases cause dye, bound to DNA, to display an increased fluorescence yield compared to that of the dye in free solution. Ultraviolet radiation at $254 \mathrm{~nm}$ is absorbed by the DNA and transmitted to the dye; radiation at $302 \mathrm{~nm}$ and $366 \mathrm{~nm}$ is absorbed by the bound dye itself. In both cases, the energy is reemitted at $590 \mathrm{~nm}$ in the red orange region of the visible spectrum. Hence, DNA can be visualized under a UV transilluminator.

The solution was poured into a gel chamber with a comb and let to solidify at room temperature. The concentration of the gel determines the optimal separation of DNA fragments different in size e.g. large fragments separate in low concentration gels where small fragments in high agarose concentration (see the table below). DNA samples were mixed with $1 / 6$ volume of $6 x$ loading buffer and loaded into the preformed wells of the gel. Gels were electrophoresed at $80-120 \mathrm{~V}$ for $1 \mathrm{~h}$ in a horizontal apparatus (Biorad, Munich) in $1 \times$ TAE buffer. After electrophoresis, the gel was placed into the transilluminator and photographed using a built-in camera and a software set (Biometra, Göttingen).

\begin{tabular}{|c|c|}
\hline Percentage of agarose & DNA fragments separated \\
\hline $0.3 \%$ & $60-5 \mathrm{~kb}$ \\
\hline $0.6 \%$ & $20-1 \mathrm{~kb}$ \\
\hline $0.7 \%$ & $10-0.8 \mathrm{~kb}$ \\
\hline $0.9 \%$ & $7-0.5 \mathrm{~kb}$ \\
\hline $1.2 \%$ & $6-0.4 \mathrm{~kb}$ \\
\hline $1.5 \%$ & $4-0.2 \mathrm{~kb}$ \\
\hline $2.0 \%$ & $3-0.1 \mathrm{~kb}$ \\
\hline
\end{tabular}

(Sambrook et al., 1989)

\section{2. 1.9 Purification of DNA from agarose gel}

DNA fragments were purified after agarose gel electrophoresis using Easy Pure DNA purification kit (Biozym, Oldendorf). After electrophoresis DNA bands were visualized 
using UV transilluminator, DNA fragments were excised from the agarose gel with sterile scalpel, transferred to sterile Eppendorf tube and mixed with $3 \times$ volumes of Salt buffer (Easy Pure DNA purification kit) to dissolve the agarose. Samples were incubated for 5 min at $55^{\circ} \mathrm{C}$ and vortexed at various intervals. Next, depending on the expected amount of DNA the buffer Bind (Easy Pure DNA purification kit) was added and incubated at RT for 5 min under constant agitation. The mixture was centrifuged for $5 \mathrm{sec}$ and the supernatant was discarded. The pellet was carefully resuspended in $1 \mathrm{ml}$ Wash buffer (Easy Pure DNA purification kit). Again the mixture was centrifuged for $5 \mathrm{sec}$ and supernatant was aspirated. The pellet was let to dry and was dissolved in $20 \mu \mathrm{l}$ TE buffer and incubated for $5 \mathrm{~min}$ at RT. DNA was eluted by centrifugation at $13,000 \mathrm{rpm}$ for $1 \mathrm{~min}$, transferred to a fresh Eppendorf tube and stored at $4^{\circ} \mathrm{C}$.

\section{2. 1. 10 Dephosphorylation of 5' protruding DNA ends}

In order to prevent vector religation in the cloning process, 5' phosphate groups were eliminated by treating digested vector with 10 units of the alkaline phosphatase (MBI Fermentas) at $37^{\circ} \mathrm{C}$ for $30 \mathrm{~min}$. In order to deactivate alkaline phosphatase, the mixture was further incubated for $30 \mathrm{~min}$ at $65^{\circ} \mathrm{C}$. The dephosphorylated DNA was purified using Easy Pure DNA purification kit (Biozym, Oldendorf) as described in 2. 2. 1. 9

\section{2. 1. 11 Ligation}

DNA ends of different fragments were ligated by incubation with T4 DNA-ligase (MBI Fermentas) at $16^{\circ} \mathrm{C}$ overnight. Ligation is the formation of a covalent bond between a $5^{\prime}$ phosphate and a 3' hydroxyl group. Ligation reaction mixture included 10-100 ng of vector and 5-10 times more insert DNA in molar quantities. Reaction was carried out in $20 \mu \mathrm{l}$ volume, using $1 \mu \mathrm{l}$ of T4 DNA-ligase in $1 \mathrm{x}$ ligation buffer (including ATP) (MBI Fermentas, St. Leon-Rot). In order to confirm identity and orientation of the inserts, DNA constructs were sequenced as described in 2. 2. 1. 13.

\section{2. 1. 12 Site-directed mutagenesis}

The site-directed mutagenesis method was performed using PfuTurbo® DNA polymerase (Invitrogen, Karlsruhe) and a temperature cycler. PfuTurbo DNA polymerase replicates both plasmid strands with high fidelity and without displacing the mutant oligonucleotide primers. The basic procedure utilizes a supercoiled double-stranded DNA (dsDNA) vector and two synthetic oligonucleotide primers containing the desired mutation (see Fig. 5). 
The oligonucleotide primers, encoding a mutation, each complementary to opposite strands of the vector, are extended during temperature cycling by PfuTurbo DNA polymerase. Incorporation of the oligonucleotide primers generates a mutated plasmid containing staggered nicks. When PCR is finished, the product must be treated with Dpnl. The Dpnl endonuclease (target sequence: $5^{\prime}-\mathrm{Gm}^{6} \mathrm{ATC}-3^{\prime}$ ) is specific for methylated and hemimethylated DNA and is used to digest the parental DNA template and to select for mutation-containing synthesized DNA. DNA isolated from almost all $E$. coli strains is dam methylated and therefore susceptible to $D p n l$ digestion. The nicked vector DNA containing the desired mutations is then transformed into DH5a cells. The small amount of starting DNA template required to perform this method, the high fidelity of the PfuTurbo DNA polymerase, and the low number of thermal cycles all contribute to the high mutation efficiency and a decreased potential for generating random mutations during the reaction.

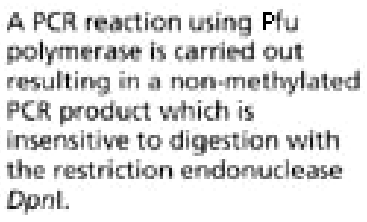

A PCR reaction using Pfu polymerase is carried out resulting in a non-methylated PCR product which is insensitive to digestion with the restriction endonuclease Dpont.

The remaining mutated
plasmid is purified and ligated.
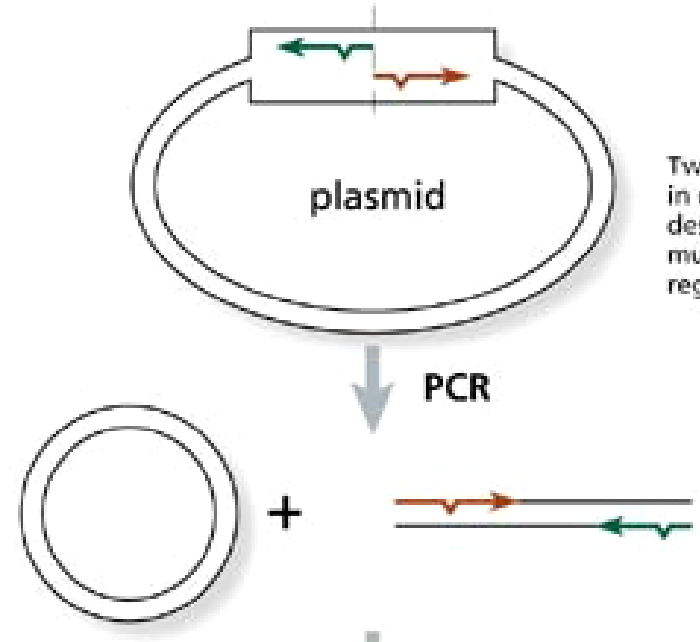

Dpnl
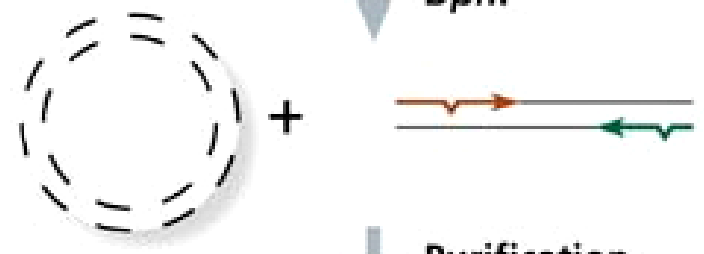

Purification

Ligation

Transformation of the

religated plasmid into $\mathrm{E}$. coli results in colonies, on selection media, which carry the desired mutation.

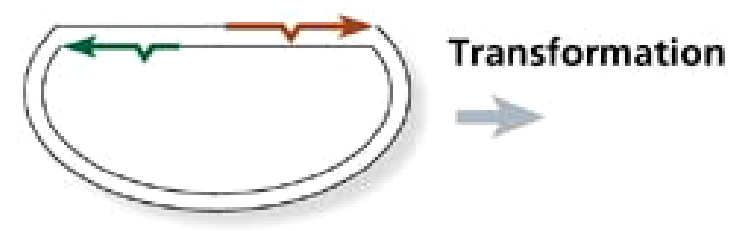

Two oligonucleotides priming in opposite orientations are designed to introduce the mutation into the required region of the plasmid.

\section{Fig. 5. Site-directed mutagenesis, general scheme (www.qbiogene.com).}

The oligonucleotide primers, encoding a mutation, each complementary to opposite strands of the vector, are extended during temperature cycling by PfuTurbo DNA polymerase resulting in a non-methylated PCR product which is not sensitive to DpnI 
treatment. Further transformation results in colonies which are carrying the desired mutation.

The following PCR conditions were used:

$\begin{array}{lll}\text { Template DNA } & (50 \mathrm{ng} / \mu \mathrm{l}) & 1 \mu \mathrm{l} \\ \text { Sense primer } & (10 \mathrm{pmol} / \mu \mathrm{l}) & 1 \mu \mathrm{l} \\ \text { Antisense primer } & (10 \mathrm{pmol} / \mu \mathrm{l}) & 1 \mu \mathrm{l} \\ \text { 10x reaction buffer } & & 5 \mu \mathrm{l} \\ \text { Pfu Turbo DNA-Polymerase } & 1 \mu \mathrm{l} \\ \text { dNTP-Mix } & (20 \mathrm{mM}) & 1 \mu \mathrm{l} \\ \mathrm{ddH}_{2} \mathrm{O} & & \text { to } 50 \mu \mathrm{l}\end{array}$

PCR was performed using the TRIO-Thermoblock (Biometra, Göttingen) according to the conditions given below:

\begin{tabular}{|c|c|c|c|}
\hline STEP & Amount of cycles & Temperature, ${ }^{\circ} \mathrm{C}$ & Time \\
\hline Initial denaturation & 1 & 95 & $30 \mathrm{sec}$ \\
\hline Denaturation & \multirow{2}{*}{13} & 95 & $30 \mathrm{sec}$ \\
\cline { 1 - 3 } Annealing & & 55 & $1 \mathrm{~min}$ \\
\cline { 1 - 3 } Elongation & 1 & 68 & $1 \mathrm{~min} / \mathrm{Kbp}$ \\
\hline & & 4 & $\infty$ \\
\hline
\end{tabular}

After the PCR, $1 \mu \mathrm{l}$ of the $D p n$ I endonuclease per sample was added and the samples were incubated $1 \mathrm{~h}$ at $37^{\circ} \mathrm{C}$ followed by direct transformation using $E$. coli $\mathrm{DH} 5 \alpha$ bacterial strain.

\section{2. 1.13 DNA sequencing}

For DNA sequencing the "dye terminator" method was used. Each ddNTP is labeled with a fluorophore that emits a different wavelength of light. The ratio of dNTPs to ddNTPs is adjusted so that adequate DNA synthesis occurs, but very few synthesis reactions will continue to the end of the template. The result is a population of DNA molecules that vary in length and extend from the primer to a labelled ddNTP at the 3' end. Ideally, the shortest molecule will contain the primer with a single ddNTP added to the 3 ' end. The 
synthesis products should also contain molecules that are terminated at the second, third, fourth, fifth and sixth incorporated bases and so on until the end of template is reached. The newly synthesized DNAs are denaturated and separated according to their length by electrophoresis through long $(\sim 35-50 \mathrm{~cm})$ and thin $(\sim 0.07 \mathrm{~mm})$ polyacrylamide-urea gels, which are capable of resolving single-stranded DNA molecules that differ in length by a single nucleotide. As each DNA band passes a light source-detector at the bottom of the gel, the color and intensity of the band are recorded and plotted as a four-color electropherogram (Fig. 6)

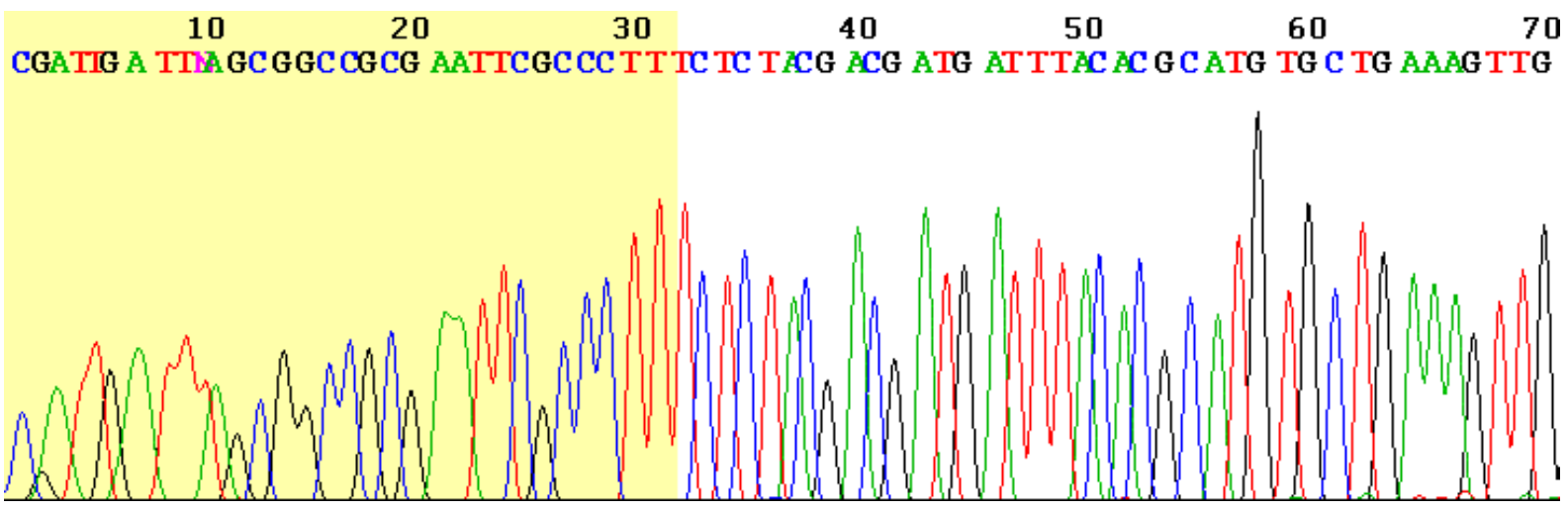

Fig. 6. A typical sequencing electropherogram

The following PCR conditions were used:

Plasmid-DNA

Primer

Big Dye-Mix

(Applied Biosystems, Darmstadt)

$\mathrm{ddH}_{2} \mathrm{O}$

$\begin{array}{ll}(100 \mathrm{ng} / \mu \mathrm{l}) & 1 \mu \mathrm{l} \\ (10 \mathrm{pmol} / \mu \mathrm{l}) & 1 \mu \mathrm{l}\end{array}$

$2 \mu \mathrm{l}$

$6 \mu \mathrm{l}$

Big Dye is a composition of fluorescent-labeled ddNTPs, dNTPs, polymerase and 10x reaction buffer.

The reaction was performed according to the program given below: 


\begin{tabular}{|c|c|c|c|}
\hline STEP & Amount of cycles & Temperature, ${ }^{\circ} \mathrm{C}$ & Time \\
\hline Initial denaturation & 1 & 94 & $2 \min$ \\
\hline Denaturation & \multirow{3}{*}{25} & 96 & $15 \mathrm{sec}$ \\
\hline Annealing & & 56.5 & $15 \mathrm{sec}$ \\
\hline Elongation & & 60 & $15 \mathrm{sec}$ \\
\hline \multirow[t]{2}{*}{ Final Elongation } & 1 & 60 & $4 \min$ \\
\hline & 1 & 4 & $\infty$ \\
\hline
\end{tabular}

After the reaction was completed, $40 \mu \mathrm{l}$ of $\mathrm{dd}_{2} \mathrm{O}$ was added to the samples followed by purification through Sephadex-Filter (Sephadex G-50, Amersham Bioscienses, Freiburg). Purified samples were anlyzed using ABI PRISM 3100 Genetic Analyzer, (Applied Biosystems, Darmstadt). The sequences were further analyzed using Chromas software tool (Technelysium Pty Ltd., Austria).

\section{2. 2 Recombinant GST-fusion protein expression in bacteria and purification}

DH5a E.coli cells were transformed with GST-CBP plasmids as described in 2. 2. 1. 3. In order to identify which of the colonies express the highest amount the recombinant protein, several colonies were chosen and inoculated overnight at $37^{\circ} \mathrm{C}$ in $3 \mathrm{ml} \mathrm{LB}$ plus ampicillin.

Next day, $100 \mu \mathrm{l}$ of the pre-cultures were used to inoculate $3 \mathrm{ml}$ LB plus ampicillin. These cultures were induced with IPTG (dissolved in water) to final concentration of $1 \mathrm{mM}$. After IPTG induction, the culture was further grown for additional $3-4 \mathrm{~h}$ at $37^{\circ} \mathrm{C}, 220 \mathrm{rpm}$. The bacteria were centrifuged at 3,000 rpm for $10 \mathrm{~min}$ at RT. The pellet was dissolved in $1 \mathrm{x}$ SDS sample buffer, loaded on a protein gel (10\%) and the gel was stained with Coomassie.

Once a colony that expressed the recombinant protein at high levels was identified, it was used to inoculate a pre-culture of $20 \mathrm{ml}$ LB plus ampicillin overnight at $37^{\circ} \mathrm{C}, 220 \mathrm{rpm}$.

The $20 \mathrm{ml}$ pre-culture was used to inoculate $1 \mathrm{~L} \mathrm{LB}$ plus amp and was grown for approximately $3 \mathrm{~h}$ until O.D.600 reached 0.6. Reference sample (non-induced) of $1 \mathrm{ml}$ was taken and culture was induced with IPTG to final concentration of $1 \mathrm{mM}$ for additional 3-4 $\mathrm{h}$ at $37^{\circ} \mathrm{C}, 220 \mathrm{rpm}$. Reference sample (induced) of $1 \mathrm{ml}$ was taken. 
The culture was centrifuged to harvest bacteria for $15 \mathrm{~min}, 3,500 \mathrm{rpm}$ at $4{ }^{\circ} \mathrm{C}$, and the pellet was resuspended in ice-cold $15 \mathrm{ml} 1 \times$ PBS with $1 \mathrm{mM}$ DTT and $1 \mathrm{mM}$ PMSF (in 50 ml Bluecap). The suspension was frozen with liquid $\mathrm{N}_{2}$ and stored overnight at $-80^{\circ} \mathrm{C}$.

Frozen bacteria suspension was slowly thawed on ice-water bath for ca. $3 \mathrm{~h}$ and Nonidet P40 detergent was added to a final concentration of $0.1 \%$. The suspension was sonicated $6 \times 45 \mathrm{sec}$ pulses of 400 Watt with 1 min intervals between pulses (during the whole process the bacteria must remain in ice-water to avoid sample overheating).

Lysate was centrifuged for $10 \mathrm{~min}$ at $10,000 \mathrm{rpm}$ at $4^{\circ} \mathrm{C}$. Supernatant was transferred into a fresh $50 \mathrm{ml}$ Bluecap, $50 \mu \mathrm{l}$ aliquot was taken from the supernatant and $1 \mathrm{ml}$ of the prehydrated glutathione agarose slurry was added. DTT was added to a final concentration of $5 \mathrm{mM}$.

The suspension was slowly agitated on a rocking platform for $1-2 \mathrm{~h}$ at $4^{\circ} \mathrm{C}$, and then the suspension was centrifuged for $5 \mathrm{~min}$ at 2,000 rpm at RT.

The pellet of agarose beads was transferred into two $2 \mathrm{ml}$ Eppendorf tubes and washed four times with $1.5 \mathrm{ml}$ PBS supplemented with $1 \mathrm{mM}$ DTT and $1 \mathrm{mM}$ PMSF. The centrifugation step during washing steps consisted of 2 min 2,000 rpm at RT. After the first washing step, $50 \mu$ aliquot was taken from the supernatant.

The protein was eluted from the beads with $4 \times 600 \mu$ l of Elution buffer (for each $500 \mu \mathrm{l}$ of beads) at RT, $10 \mathrm{~min}$ at $750 \mathrm{rpm}$ in Eppendorf thermomixer (centrifuge $2 \mathrm{~min}$ 2,000 rpm at $\mathrm{RT}$ ). The eluates and the beads are stored at $4^{\circ} \mathrm{C}$ (volume of each eluate was approx. 600 $\mu l)$.

In order to recognize the eluates containing high amounts of the protein, $100 \mu$ l aliquotes of the diluted Bradford reagent (Bradford, 1976) (dilution ratio 1:5) were pipetted into a 6well plate, $5 \mu$ of each eluate was added and carefully mixed. If the mix was colored in blue, this eluate was indicating a high amount of protein. These eluates were mixed and placed in dialysis tubing (Sigma, Taufkirchen) and dialysed twice against 1-2 L of dialysis buffer overnight at $4^{\circ} \mathrm{C}$.

After dialysis, the protein concentration was measured using standard Bradford reagents (Bradford M., 1976). Protein samples were stored at $-80^{\circ} \mathrm{C}$.

All reference samples together with the dialysed proteins and the beads were mixed with $2 \times$ SDS sample buffer, heated at $95^{\circ} \mathrm{C}$ and loaded on an SDS-PAGE gel.

\section{Elution buffer $(10-20 \mathrm{ml})$ :}

$50 \mathrm{mM}$ glutathione in $50 \mathrm{mM}$ Tris $\mathrm{pH} 7.4$

(adjust the $\mathrm{pH}$ between 7.0 and 7.5 after addition of glutathione) 


\section{Dialysis buffer :}

Tris $\mathrm{pH} 7.4$

$\mathrm{NaCl}$

EDTA

DTT

PMSF
$20 \mathrm{mM}$

$100 \mathrm{mM}$

$0.2 \mathrm{mM}$

$1 \mathrm{mM}$

$0.5 \mathrm{mM}$

Glutathione agarose slurry :

$80 \mathrm{mg}$ of Glutathione Agarose was suspended in $1 \mathrm{ml}$ PBS to hydrate (ON at $4^{\circ} \mathrm{C}, 750$ rpm) and then the beads were washed four times with $1 \mathrm{ml}$ PBS and resuspended in $1 \mathrm{ml}$ PBS plus $1 \mathrm{mM}$ DTT plus $1 \mathrm{mM}$ PMSF and stored at $4^{\circ} \mathrm{C}$.

\section{2. 3 Extraction of nuclear proteins}

Nuclear proteins were isolated from InR1G9 cells following the procedure of Schreiber et al., 1989. Per sample, 6-cm diameter, fully confluent plates were used. A 6-cm plate was washed with 5-8 $\mathrm{ml}$ ice-cold TBS Buffer. Cells were removed by scraping in $2 \mathrm{ml}$ of icecold TBS Buffer and transferred to $15 \mathrm{ml}$ tube. The plate was washed again with $8 \mathrm{ml}$ TBS Buffer and the cell suspension was added to the same $15 \mathrm{ml}$ tube. The cells were centrifuged for $2 \mathrm{~min}, 1,600 \mathrm{rpm}$, RT (Heraeus Megafuge 1.0), the pellet was resuspended in $1 \mathrm{ml}$ ice-cold TBS Buffer, transferred to a fresh Eppendorf tube and centrifuged for 2 min at $1,600 \mathrm{rpm}, 4^{\circ} \mathrm{C}$ (Eppendorf $5415 \mathrm{C}$ ). The pellet was resuspended in $400 \mu$ ice-cold Buffer A and incubated for $15 \mathrm{~min}$ on ice. $25 \mu$ of $10 \%$ Nonidet P 40 was added and the sample was vortexed for $10 \mathrm{sec}$. Sample was centrifuged for $2 \mathrm{~min}, 6,000 \mathrm{rpm}, 4^{\circ} \mathrm{C}$ (Eppendorf 5415C), and the supernatant, containing the cytoplasmatic fraction, was discarded. The pellet was resuspended in $50 \mu$ ice-cold Buffer $C$ and shaken in Eppendorf thermomixer at $300 \mathrm{rpm}, 4^{\circ} \mathrm{C}$ for $20 \mathrm{~min}$. The sample was centrifuged for 4 min, at $14,000 \mathrm{rpm}, 4^{\circ} \mathrm{C}$. The supernatant was collected (ca. $55 \mu \mathrm{l}$ ) and stored at $-80^{\circ} \mathrm{C}$. For EMSA, 5-9 $\mu \mathrm{l}$ of freshly prepared extracts were used.

\section{Buffer A}

$\begin{array}{ll}\text { HEPES pH 7.9 } & 10 \mathrm{mM} \\ \text { KCI } & 10 \mathrm{mM} \\ \text { EDTA } & 0.1 \mathrm{mM} \\ \text { EGTA } & 0.1 \mathrm{mM} \\ \text { DTT } & 1 \mathrm{mM} \\ \text { PMSF } & 0.5 \mathrm{mM}\end{array}$




\section{Buffer C}

$\begin{array}{lcc}\text { HEPES pH } 7.9 & 20 & \mathrm{mM} \\ \mathrm{NaCl} & 400 & \mathrm{mM} \\ \text { EDTA } & 1 & \mathrm{mM} \\ \text { EGTA } & 1 & \mathrm{mM} \\ \text { DTT } & 1 & \mathrm{mM} \\ \text { PMSF } & 1 & \mathrm{mM}\end{array}$

\section{$\underline{\text { TBS Buffer }}$}

$\begin{array}{ll}\mathrm{NaCl} & 8 \mathrm{~g} \\ \mathrm{KCl} & 0.2 \mathrm{~g} \\ \mathrm{Tris} & 3 \mathrm{~g} \\ \mathrm{ddH}_{2} \mathrm{O} & \text { to } 1 \mathrm{~L}\end{array}$

$\mathrm{pH}$ was adjusted to 7.4 with $\mathrm{HCl}$.

\section{2. 4 SDS polyacrylamide gel electrophoresis}

Analytical SDS gel electrophoresis of proteins is carried out in polyacrylamide gels under conditions that ensure dissociation of the proteins into their individual polypeptide subunits and that minimize aggregation. The strongly anionic detergent SDS is used in combination with a reducing agent ( $\beta$-mercaptoethanol) and heat to denaturate the proteins before they are loaded onto the gel. The denatured polypeptides bind SDS and become negatively charged. Because the amount of SDS bound is almost always proportional to the molecular weight of the polypeptide and is independent of its sequence, SDS-polypeptide complexes migrate through polyacrylamide gels in accordance with the size of the polypeptide. By using markers of known molecular weight it is therefore possible to estimate the molecular weight of the polypeptide chain.

SDS-polyacrylamide gel electrophoresis is carried out with a discontinuous buffer system in which the buffer in the reservoirs is of a different $\mathrm{pH}$ and ionic strength from the buffer is used to cast the gel. After migrating through a stacking gel of high porosity, the complexes are deposited in a very thin zone on the surface of the resolving gel. The ability of discontinuous buffer systems to concentrate all of the complexes in the sample into a very small volume greatly increases the resolution of SDS-polyacrylamide gels.

The stacking gel contains Tris $(\mathrm{pH}$ 6.8), the upper and the lower buffer reservoirs contain Tris-glycine $(\mathrm{pH} \mathrm{8.3)}$ and the resolving gel contains Tris $(\mathrm{pH} \mathrm{8.8).} \mathrm{All} \mathrm{components} \mathrm{of} \mathrm{the}$ system contain $0.1 \%$ SDS. In this study $4 \%$ stacking gel and $10-15 \%$ resolving gel were prepared and electrophoresis was run in Mighty Small-System apparatus, SE 250 
(Hoefer, San Francisco) in 1 x running buffer at a constant current of $25 \mathrm{~mA}$. Before loading the protein samples were mixed with loading buffer and denatured by incubation for $5 \mathrm{~min}$ at $95^{\circ} \mathrm{C}$. After electrophoresis the gel was stained with Coomassie-Blue Solution for $30 \mathrm{~min}$ at RT. Destaining was done by incubating in destaining solution for $4 \mathrm{~h}$ changing the solution 3-4 times.

$10 \%$ Resolving Gel :

$\begin{array}{lll}\text { Acrylamide Mix } & 3.33 \mathrm{ml} \\ \text { Resolving Buffer (1.5 mM Tris pH 8.8) } & 2.5 & \mathrm{ml} \\ \mathrm{ddH}_{2} \mathrm{O} & 4 & \mathrm{ml} \\ 10 \% \text { SDS } & 100 & \mu \mathrm{l} \\ 10 \% \text { APS }(0.1 \mathrm{~g} / 1 \mathrm{ml} \text { in water }) & 100 & \mu \mathrm{l} \\ \text { TEMED } & 6 & \mu l\end{array}$

$\underline{4 \% \text { Stacking Gel : }}$

Acrylamide Mix $\quad 0.67 \mathrm{ml}$

Stacking Buffer (0.5 M Tris pH 6.8) $\quad 1.25 \mathrm{ml}$

$\mathrm{ddH}_{2} \mathrm{O} \quad 3 \mathrm{ml}$

$10 \%$ SDS $\quad 50 \mu \mathrm{l}$

$10 \%$ APS $(0.1 \mathrm{~g} / 1 \mathrm{ml}$ in water $) \quad 50 \mu \mathrm{l}$

TEMED $2.4 \mu \mathrm{l}$

Acrylamide Mix :

Acrylamide

Bisacrylamide

$\mathrm{dd}_{2} \mathrm{O}$

Loading Buffer $(2 \mathrm{x})$ :

Tris $\mathrm{pH} 6.8$

Bromophenolblue

SDS

Glycerol

$\beta$-mercaptoethanol
$125 \mathrm{mM}$

$29.2 \mathrm{~g}$

$0.8 \mathrm{~g}$

$100 \mathrm{ml}$

$1 \mathrm{mg} / 1 \mathrm{ml}$

$4 \%$

$20 \%$

$10 \%$ 
Staining solution (per $100 \mathrm{ml}$ ):

Methanol

$45 \mathrm{ml}$

$\mathrm{dd}_{2} \mathrm{O}$

$45 \mathrm{ml}$

Acetic acid

$10 \mathrm{ml}$

Coomassie blue R250

$0.25 \mathrm{~g}$

Destaining solution (per $100 \mathrm{ml}$ ):

Methanol

$45 \mathrm{ml}$

Water

$45 \mathrm{ml}$

Acetic acid

$10 \mathrm{ml}$

Running buffer $(5 x)$ :

Tris $\mathrm{pH} 8.3$

$25 \mathrm{mM}$

Glycine

$192 \mathrm{mM}$

SDS

$0.1 \%$

\section{2. 5 Preparation of proteins for MALDI-TOF mass spectrometry}

After visualization of the proteins with Coomassie Blue staining, the band, containing the protein of interest, as identified by its molecular weight, was cut out for analysis using MALDI-TOF mass spectrometry.

\section{2. 5. 1 In-gel digest of proteins stained with Coomassie}

Before excising bands, the gel was washed twice in $\mathrm{ddH}_{2} \mathrm{O}$ for 15 minutes. The bands, containing proteins of interest were excised with a scalpel, cut into $1 \mathrm{~mm}$ cubes, and placed in an Eppendorf tube. $100 \mu$ of $\mathrm{dd}_{2} \mathrm{O}$ was added and incubated for $15 \mathrm{~min}$. the water was discarded, $40 \mu \mathrm{l}$ of $50 \%$ acetonitrile (ACN) was added and samples were incubated for 15 minutes. The solution was pulled off, $40 \mu \mathrm{l}$ of $100 \%$ ACN was added and incubated until gel pieces became white and sticky. The solution was discarded and $40 \mu \mathrm{l}$ of $100 \mathrm{mM}$ ammonium bicarbonate (ambic) was added and incubated for 5 minutes. $40 \mu \mathrm{l}$ of $100 \%$ ACN was added to make $1: 1$ solution and incubated for 15 minutes. The solution was discarded and the sample was dried in speed vac for $20 \mathrm{~min}$. Next, $40 \mu \mathrm{l}$ (enough to cover pieces) of trypsin solution was added and incubated for $45 \mathrm{~min}$ at $4^{\circ} \mathrm{C}$. The excess of the solution was discarded, $10 \mu \mathrm{l}$ of trypsin digestion buffer was added and incubated overnight at $37^{\circ} \mathrm{C}$. 
Next morning, the supernatant was transferred into a fresh Eppendorf tube, $20 \mu \mathrm{l}$ of 25 $\mathrm{mM}$ Ambic was added and incubated for $15 \mathrm{~min}$ at RT. $20 \mu \mathrm{l}$ of $100 \%$ ACN was added to make 1:1 solution and incubated for 15 minutes at RT. The liquid phase was transferred to the Eppendorf tube containing solution after overnight digestion. Again, $20 \mu \mathrm{l}$ of $5 \%$ formic acid was added to the gel pieces and incubated for 15 minutes at RT. $20 \mu \mathrm{l}$ of $100 \%$ ACN was added to make 1:1 solution and incubated for 15 minutes at RT, the supernatant was collected into the Eppendorf tube mentioned above. Treatment with 5\% formic acid and ACN was repeated two more times and DTT was added to the collected supernatants to a final concentration of $1 \mathrm{mM}$. The samples were dried in speed vac, resuspended in $15 \mu \mathrm{l}$ of $5 \%$ formic acid and subjected to MALDI-TOF analysis.

\section{Stock solutions}

$100 \mathrm{mM} \mathrm{Ambic}\left(\mathrm{NH}_{4} \underline{\mathrm{HCO}}_{3}\right)$
Ambic $\left(\mathrm{NH}_{4} \mathrm{HCO}_{3}\right) \mathrm{HPLC}$-grade
$79 \mathrm{mg}$
$\mathrm{H}_{2} \mathrm{O}$
to $10 \mathrm{ml}$

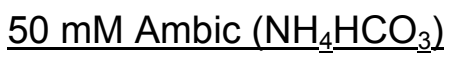
Ambic $\left(\mathrm{NH}_{4} \mathrm{HCO}_{3}\right)$ HPLC-grade
$39.503 \mathrm{mg}$
HPLC-grade $\mathrm{H}_{2} \mathrm{O}$
to $10 \mathrm{ml}$

$100 \%$ Acetonitrile (ACN) (ready to use solution)

\section{$\underline{\text { Trypsin stock }}$}

Final concentration

$\begin{array}{lll}\text { Trypsin } & 20 \mu \mathrm{g} & 0.1 \mu \mathrm{g} / \mu \mathrm{l} \\ 1 \mathrm{mM}(12 \%) \mathrm{HCl} & 200 \mu \mathrm{l}\end{array}$

\section{Working solutions}

$25 \mathrm{mM}$ Ambic $\left(\underline{\mathrm{NH}}_{4} \underline{\mathrm{HCO}_{3}} \underline{\underline{ }}\right)$

$\begin{array}{ll}50 \mathrm{mM} \mathrm{Ambic}\left(\mathrm{NH}_{4} \mathrm{HCO}_{3}\right) & 5 \mathrm{ml} \\ \text { HPLC-grade } \mathrm{H}_{2} \mathrm{O} & 5 \mathrm{ml}\end{array}$


$\underline{50 \% \mathrm{AcN} / 25 \mathrm{mM} \mathrm{NH}} \underline{\mathrm{HCO}}_{3}$

$\begin{array}{ll}50 \mathrm{mM} \mathrm{Ambic}\left(\mathrm{NH}_{4} \mathrm{HCO}_{3}\right) & \text { For } 10 \mathrm{ml} \\ 100 \% \text { AcN } & 500 \mu \mathrm{l} \\ & 500 \mu \mathrm{l}\end{array}$

Trypsin-digestion buffer

$\begin{array}{lll}100 \mathrm{mM} \mathrm{Ambic}\left(\mathrm{NH}_{4} \mathrm{HCO}_{3}\right) & 50 \mu \mathrm{l} \\ 100 \mathrm{mM} \mathrm{CaCl} & & 5 \mu \mathrm{l} \\ \text { HPLC-grade } \mathrm{H}_{2} \mathrm{O} & 53 \mu \mathrm{l} \\ 0.1 \mu \mathrm{g} / \mu \mathrm{l} \text { trypsin } & 12 \mu \mathrm{l} \\ \text { Total volume } & 120 \mu \mathrm{l}\end{array}$

$\underline{5 \% \text { formic acid }}$

$100 \%$ formic acid $\quad 0.5 \mathrm{ml}$

HPLC-grade $\mathrm{H}_{2} \mathrm{O} \quad 9.5 \mathrm{ml}$

\section{2. 5. 2 Extraction of peptides from the gel after trypsin digestion}

After the trypsin digestion was completed, the tubes with the samples were shortly centrifuged in an Eppendorf bench-top MiniSpin centrifuge and the supernatants transferred to new tubes. $50 \mu \mathrm{l}$ of $1 \%$ TFA were added to each sample and the mixture was incubated for 30 minutes at $37^{\circ} \mathrm{C}$ for peptide extraction. To make the latter more efficient, the samples were sonicated for 10 minutes at room temperature. After short centrifugation, the supernatants were recovered and pooled with the first supernatant of the corresponding sample. The samples were lyophilized in a speed-vac (concentrator) for 1 hour and 15 minutes. The obtained lyophilisates were reconstituted in $10 \mu \mathrm{l}$ of $0.1 \%$ TFA and sonicated for 5 minutes at room temperature. Prepared samples were dried under vacuum and further subjected for MALDI-TOF analysis.

$\underline{1 \% \text { trifluoracetic acid (TFA) }}$

$\begin{array}{ll}100 \% \text { TFA } & 100 \mu \mathrm{l} \\ \text { HPLC-grade } \mathrm{H}_{2} \mathrm{O} & \text { to } 10 \mathrm{ml}\end{array}$


$\underline{0.1 \% \text { TFA }}$

$1 \%$ TFA

$1 \mathrm{ml}$

HPLC-grade $\mathrm{H}_{2} \mathrm{O}$

to $10 \mathrm{ml}$

\section{2. 5. 3 Cyanogen Bromide cleavage of the peptides after in-gel digestion with} trypsin

The following protocol was used (van Montfort and Doeven et al., 2002, van Montfort and Canas et al., 2002). After digestion with trypsin obtained samples were dried in the Speed-Vac. Subsequently, CNBr cleavage was started by addition of $15 \mu$ of $100 \%$ TFA in which 1-2 small crystalls of cyanogene bromide were dissolved. The reaction was performed in the dark (tubes containing samples were covered with aluminium foil) at RT overnight. Next morning, $\mathrm{CNBr}$ was removed by vacuum centrifugation and the samples were further subjected to MALDI-TOF analysis.

\section{2. 6 Immunoprecipitation}

Immunoprecipitation is a technique that uses antibodies specific to a protein to remove this protein from a solution. The antibody-protein complexes are precipitated out of solution with the addition of an insoluble form of antibody binding proteins (e.g. Protein A), or the addition of a second antibody to the solution (Fig. 7).
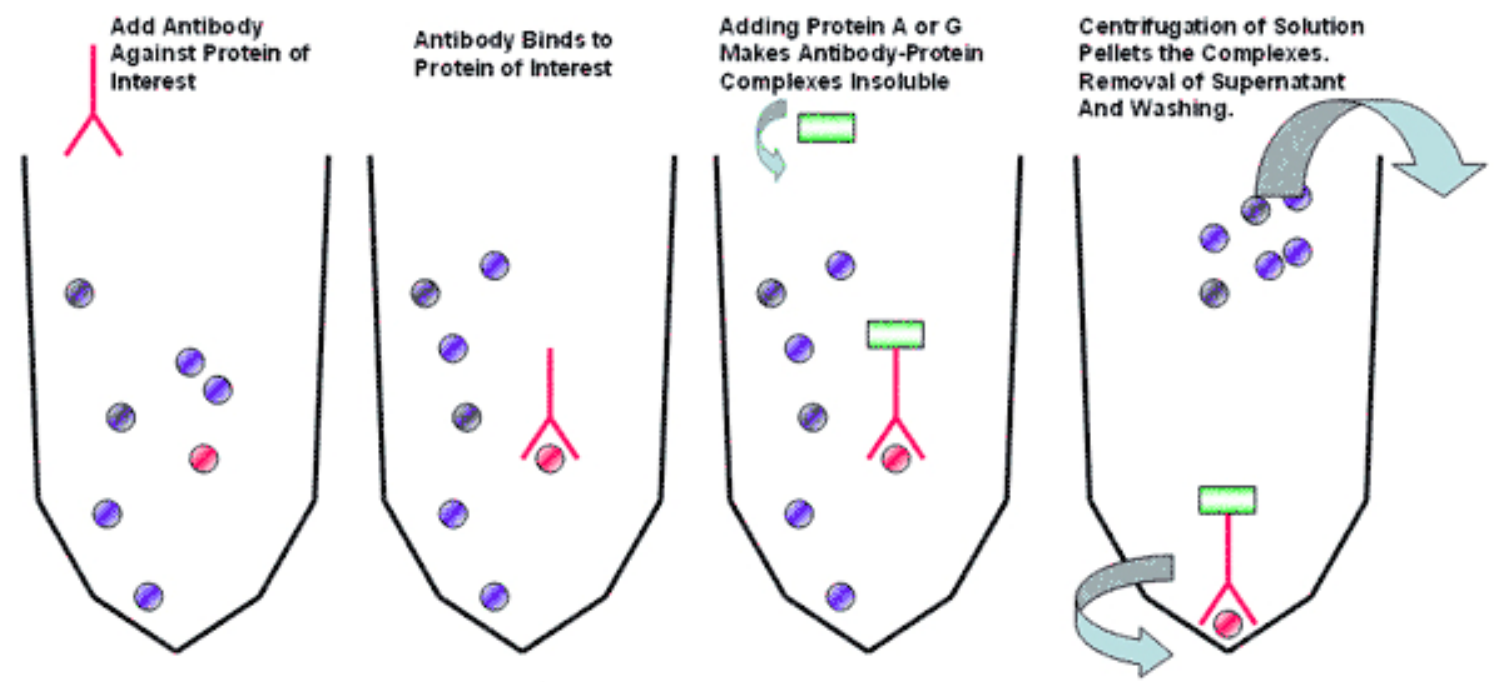
Fig. 7. Scheme, representing general immunoprecipitation steps

(www.molecularstation.org)

After adding the primary antibody it binds to the protein of interest. Adding Protein $A$ makes Antibody-Protein complex insoluble. Thus, it can be pelleted by centrifugation and subjected for immunodetection.

InR1G9 cells were transfected as described in 2. 2. 11. 3. $48 \mathrm{~h}$ after transfection, the medium was discarded and cells were washed with $2 \mathrm{ml}$ ice-cold PBS and placed on ice with water. PBS was discarded and $270 \mu \mathrm{l}$ of Cellytic Lysis buffer (Sigma, Taufkirchen), supplemented with protease inhibitors cocktail was added and samples were incubated for $15 \mathrm{~min}$ on ice bath. Cells were scraped, obtained samples were centrifugated at $11,000 \mathrm{rpm}$ for $15 \mathrm{~min}$ at $4^{\circ} \mathrm{C}$. The supernatant was carefully transferred into fresh icecold Eppendorf-tube and $1 \mu \mathrm{l}$ of anti-HA antibody (0.8 $\mu \mathrm{g} / \mu \mathrm{l})$ (Sigma, Taufkirchen) was added. Binding reaction was carried out under constant agitation at $4^{\circ} \mathrm{C}$ overnight. Next day, $20 \mu \mathrm{l}$ of the Fast flow Protein A agarose beads were spun down ( $1 \mathrm{~min}, 12000 \times \mathrm{g}$ ), the supernatant was discarded, and the beads were washed twice with $1 \mathrm{ml}$ RIPA buffer. Mixture, containing protein-antibody complex was added to the beads and incubated for 2 hours at $4^{\circ} \mathrm{C}$. Then the beads were spun down, the supernatant was discarded and the beads were washed 4 times with $1 \mathrm{ml}$ RIPA-buffer including protease inhibitors and once with PBS. The pellet was resuspended in 2x SDS-PAGE sample buffer and boiled for 5 $\min$ at $98^{\circ} \mathrm{C}$.

RIPA buffer:

TRIS

Deoxycholate

NP-40

$\mathrm{NaCl}$

EDTA, pH 7.4

Protease inhibitors cocktail:

PMSF

Leupeptin

Pepstatin

Aprotinin

+ phosphotase inhibitors:

Okadaic acid

Sodium orthovanadate
$50 \mathrm{mM}$

$0.25 \%(w / v)$

$1 \%$

$150 \mathrm{mM}$

$1 \mathrm{mM}$ 


\section{2. 7 Western Blot Analysis}

In western blotting, the samples to be assayed are solubilized with detergents and reducing agents, separated by SDS-polyacrylamide gel electrophoresis and transferred to a solid surface such as a nitrocellulose filter. The filter is subsequently exposed to unlabeled antibodies specific for the target protein. Finally, the bound antibody is detected by secondary immunological reagent.

The following protocol was used:

The samples after immunoprecipitation (see chapter 2.2.6 for details) were separated by SDS-PAGE and the SDS gel was incubated for $20 \mathrm{~min}$ in Buffer C. During this time, the membrane used for blotting (Hybond-ECL ${ }^{\mathrm{TM}}$, Nitrocellulose, Amersham Biosciensce) was incubated for a few seconds in water and then immersed for 10 min in Buffer B.

The proteins were electroblotted from the gel to the membrane using dry electroblotting apparatus (Scientific Equipment Workshop, Clinic of Göttingen University) under constant current of $70 \mathrm{~mA}$ for $1.5 \mathrm{~h}$. The arrangement of blotting stack was as following: (from "positive" - bottom to "negative" - top electrode) two layers of Whatman paper, soaked in Buffer A, two layers of Whatman paper, soaked in Buffer B, membrane, soaked in Buffer B, gel, soaked in Buffer C, four layers of Whatman paper, soaked in Buffer C.

After electroblotting the membrane was blocked to prevent unspecific protein binding by incubation for $1 \mathrm{~h}$ at RT in Blocking solution. The membrane was then washed three times in TBS-T or PBS-T buffer for 15 min at RT (Mini Rocking Platform).

The primary antibody (differently diluted according to manufactures instructions) in blocking solution was applied to membrane and incubated overnight at $4^{\circ} \mathrm{C}$ under constant agitation.

The membrane was then washed three times in TBS-T or PBS-T buffer for 15 min at RT always on the rocking platform. The membrane was incubated with secondary antibody (depending on the source of the primary antibody), which was diluted in blocking buffer $(1: 10000)$ and incubated for $1 \mathrm{~h}$ at RT. The membrane was then washed three times with TBS-T or PBS-T buffer for $15 \mathrm{~min}$ at RT.

The proteins were visualised using ECL Western Blotting System - Amersham Pharmacia, Vienna (Horse Radish Peroxidase-catalysed chemiluminescence detection). Shortly, the membrane was incubated for $1 \mathrm{~min}$ in $2 \mathrm{ml}$ of developing mixture $(1 \mathrm{ml}$ of Solution A and $1 \mathrm{ml}$ of Solution $\mathrm{B}$ ) and then was wrapped in saran foil and exposed to $\mathrm{X}$ Ray films (Hyperfilm MP, Amersham, Braunschweig) for time intervals ranging from 0.5 to 5 min in X-Ray cassettes (Kodak X-Omatic) at RT. The films were developed by incubating ca. $15 \mathrm{sec}$ in developer solution (LX 24, Kodak) then short wash in water and 
incubation in fixation solution for ca. $15 \mathrm{sec}$ ( $A L$ 4, Kodak). After the final wash in water, the film was air-dried.

Buffer A (approx. pH 11.3):

Tris $300 \mathrm{mM}$

Methanol $20 \%(v / v)$

Buffer B (approx. pH 10.5):

Tris $25 \mathrm{mM}$

Methanol $20 \%(\mathrm{v} / \mathrm{v})$

Buffer $\mathrm{C}$ (adjust $\mathrm{pH}$ to 9.0 with borate acid) :

Tris $25 \mathrm{mM}$

Methanol

$20 \%(v / v)$

Blocking Solutions:

TBS-T buffer with 5\% (w/v) Skim Milk Powder (Fluka, \#70166)

PBS-T buffer with 5\% (w/v) Skim Milk Powder (Fluka, \#70166)

TBS-T buffer :

Tris $\mathrm{pH} 8.0$

$10 \mathrm{mM}$

$\mathrm{NaCl}$

$150 \mathrm{mM}$

Tween-20

$0.1 \%(v / v)$

PBS-T buffer :

$\mathrm{NaCl}$

$140 \mathrm{mM}$

$\mathrm{KCl}$

$2.5 \mathrm{mM}$

$\mathrm{Na}_{2} \mathrm{HPO}_{4}$

$8.1 \mathrm{mM}$

$\mathrm{KH}_{2} \mathrm{PO}_{4}$

$1.5 \mathrm{mM}$

Tween-20

$0.1 \%(\mathrm{v} / \mathrm{v})$

$\mathrm{pH}$ adjusted to 7.4

\section{2. 8 EMSA (electrophoretic mobility shift assay)}

EMSA technique was used for investigation of protein-DNA interactions. It relies on the observation that protein-DNA complexes migrate in non-denaturating acrylamide gels 
slower than the free, not protein-bound DNA fragment. In these experiments, nuclear extracts from InR1G9 cells (2. 2. 3) were used.

An annealing reaction was used in order to get dsDNA (probe) which was further radioactively labelled using $\left(\alpha-{ }^{32} P\right)$-dCTP by a Klenow fill-in reaction. The annealing reaction was carried out in a total volume of $15 \mu \mathrm{l}$ in a slowly cooling waterbath (starting temperature $85-95^{\circ} \mathrm{C}$ ) overnight as presented below:

Annealing reaction:

$\begin{array}{ll}\text { Primer } 1(100 \mathrm{pM}) & 1 \mu \mathrm{l} \\ \text { Primer } 2(100 \mathrm{pM}) & 1 \mu \mathrm{l} \\ \mathrm{NaCl}(50 \mathrm{mM}) & 3 \mu \mathrm{l} \\ \mathrm{ddH}_{2} \mathrm{O} & 10 \mu \mathrm{l}\end{array}$

Radioactive labeling of DNA oligonucleotides by Klenow "fill-in" reaction

Double-stranded DNA probes possessing 5'-GATC overhangs were labeled using $\alpha{ }^{32} \mathrm{P}$ dCTP and the Klenow fragment of DNA Polymerase I. The "fill-in" reaction was set up on ice in a total volume of $30 \mu \mathrm{l}$ :

$\begin{array}{ll}\text { ds DNA }(5 \text { pmole }) & 7.5 \mu \mathrm{l} \\ \text { dATP }(1 \mathrm{mM}) & 1.5 \mu \mathrm{l} \\ \text { dTTP }(1 \mathrm{mM}) & 1.5 \mu \mathrm{l} \\ \text { dGTP }(1 \mathrm{mM}) & 1.5 \mu \mathrm{l} \\ \left(\alpha^{32} \mathrm{P}\right) \text {-dCTP }(\sim 10 \mu \mathrm{Ci} / \mu \mathrm{l}) & 3 \mu \mathrm{l} \\ \text { Klenow Buffer }(10 \mathrm{x}) & 3 \mu \mathrm{l} \\ \text { Klenow enzyme }(2 \mathrm{U} / \mu \mathrm{l}) & 2 \mu \mathrm{l} \\ \text { dd }_{2} \mathrm{O} & 10 \mu \mathrm{l}\end{array}$

The reaction mixture was incubated for $30 \mathrm{~min}$ at room temperature and $5 \mathrm{~min}$ at $65^{\circ} \mathrm{C}$. Unincorporated nucleotides and salts were removed using mini Quick Spin Columns (Roche Applied Science, Mannheim) according to the manufacturers instructions: the column matrix was thoroughly resuspended. The top cap was removed, the bottom tip was snapped off and placed into a clean Eppendorf tube. The column was spun for $1 \mathrm{~min}$ at $3,200 \mathrm{rpm}$ to remove the residual buffer and the column was placed into fresh Eppendorf tube. The probe was carefully applied to the center of the column bed followed by centrifugation for $4 \mathrm{~min}$ at 3,200 rpm. The eluate, contaning the purified probe, was transferred into a fresh Eppendorf tube. $1 \mu \mathrm{l}$ of the eluate was mixed with $5 \mathrm{ml}$ of 
Scintillation Liquid (Quicksafe A, Zinser Analytic, Frankfurt) and the measurement of the radioactivity incorporation was done using scintillation counter (Beckman LS 1801, Munich). The probe was then diluted to a final activity of $15,000-20,000 \mathrm{cpm} / \mu \mathrm{l}$.

The binding reaction

The binding reaction was set up on ice in total volume of $20 \mu \mathrm{l}$ as presented below. The binding buffer, nuclear extract or bacterially expressed protein plus poly $\mathrm{dl} / \mathrm{dC}$ were mixed and incubated on ice for $10 \mathrm{~min}$ (non-specific competition). Then the probe was added and the incubation was continued for another $15 \mathrm{~min}$. The reaction was stopped by addition of $4 \mu \mathrm{l}$ of $6 \mathrm{x}$ Stop Mix and immediately loaded on the nondenaturing polyacrylamide gel.

Binding Reaction:

5x Binding Buffer

Nuclear Extract plus water

$4 \quad \mu \mathrm{l}$

Poly dl/dC $(1 \mu \mathrm{g} / \mu \mathrm{l})$

$11 \mu \mathrm{l}$

Probe $(20,000 \mathrm{cpm} / \mu \mathrm{l})$

$4 \mu \mathrm{l}$

$1 \mu l$

1x Binding Buffer:

HEPES, pH $7.9 \quad 20 \mathrm{mM}$

$\mathrm{KCl}$

$140 \mathrm{mM}$

EDTA, pH 8.0

$1 \mathrm{mM}$

DTT

$0.5 \mathrm{mM}$

Glycerol

$10 \%(v / v)$

\section{$\underline{6 \times \text { Stop mix }}$}

Glycerol

$30 \% \quad(v / v)$

Bromophenol Blue

$0.25 \%(\mathrm{w} / \mathrm{v})$

Xylene Cyanol FF

$0.25 \%(w / v)$

\section{2. 9 Non-denaturating Gel Electrophoresis}

The EMSA binding reaction (see above) was resolved on a nondenaturating $5 \%$ polyacrylamide gel (1x TBE). The gel was prepared by pouring the gel mix into a set of 
glass plates $(15 \times 10 \mathrm{~cm}$ ) placed in a gel casting base (SE 600, Hoefer, San Francisco, USA). The gel was run prior to the loading of the samples for $30 \mathrm{~min}$. After loading of the samples, the electrophoresis was run for 1-2 hrs at room temperature, under the voltage of $180 \mathrm{~V}$. Then the gel was transferred on Whatman paper, covered with plastic foil and dried under vacuum $\left(70^{\circ} \mathrm{C}, 1 \mathrm{~h}\right)$. Dry gel was subjected to autoradiography.

\section{5\% Gel Composition:}

Acrylamide/Bisacrylamide (38\% / 2\%) $\quad 6.25 \mathrm{ml}$

$5 \times$ TBE

$5 \mathrm{ml}$

$\mathrm{dd} \mathrm{H}_{2} \mathrm{O}$

$38.5 \mathrm{ml}$

APS (10\%)

$250 \mu \mathrm{l}$

TEMED

$25 \mu \mathrm{l}$

\section{2. 10 Phosphorylation of GST-fusion proteins by recombinant GSK3 $\beta$ in vitro}

GST-fusion proteins were purified as decribed in 2. 2. 2. $5 \mu \mathrm{l}$ of GST-beads were preincubated with $10 \mu \mathrm{l}$ of the GST-CBP fusion protein for $15 \mathrm{~min}$. Next, active recombinant GSK3 $\beta$ (50 $\mathrm{mU}$ per assay, New England Biolabs) was added to the beads with proteins in the presence of $25 \mu \mathrm{M}$ ATP plus $5 \mu \mathrm{Ci} \mathrm{y}^{32} \mathrm{P}-\mathrm{ATP}$. The mixture was incubated at $30^{\circ} \mathrm{C}$ for $30 \mathrm{~min}$ in the Eppendorf thermomixer at $1,000 \mathrm{rpm}$. It was then centrifuged at 2,500 rpm at RT for 2 min and the supernatant was carefully discarded. Beads were washed $2 \mathrm{x}$ in $175 \mu \mathrm{l}$ reaction buffer and finally dissolved in $15 \mu \mathrm{l} 2 \mathrm{x}$ SDSPAGE sample buffer and incubated for $5 \mathrm{~min}$ in an Eppendorf thermomixer at $98^{\circ} \mathrm{C}$ (this step released the GST-fusion protein from the beads). The mixture was centrifuged at $10,000 \mathrm{rpm}$ at RT for $2 \mathrm{~min}$ and then $15 \mu \mathrm{l}$ of the supernatant were loaded on a $10 \%$ SDSPAGE gel. After electrophoresis, the gel was stained with Coomassie for 20 min and destained $4 \mathrm{~h}$. Next, the gel was dried using gel-dryer and placed over a phosphorimager screen in a cassette overnight. The screen was scanned using phophorimager reader (Fujix BAS 1500, Raytest, Straubenhardt) and the data were subject to software analysis by TINA DATA Reader.

"hot" reaction mixture:

GST-beads plus GST-CBP-fusion proteins $(3 \mu \mathrm{g}) \quad 15 \mu \mathrm{l}$

GSK3 $\beta$ (50 $\mathrm{mU}$ of the enzyme in $1 \times$ Reaction buffer) $10 \mu \mathrm{l}$

ATP $\left(25 \mu \mathrm{M}\right.$ ATP in 1 x Reaction buffer plus $\left.5 \mu \mathrm{Ci} \mathrm{Y}^{-32} \mathrm{P}-\mathrm{ATP}\right) \quad 10 \mu \mathrm{l}$ 
Reaction buffer $(1 \mathrm{x})$ :

Tris $\mathrm{pH} 7.5$

$50 \mathrm{mM}$

$\mathrm{MgCl}_{2}$

$10 \mathrm{mM}$

DTT

$5 \mathrm{mM}$

\section{2.11 Eukaryotic cell culture methods}

All experiments and treatments of cells were performed under sterile conditions using sterile hood (Heraeus, Hamburg). Solutions and media were sterilized either by autoclaving or by filtering and prewarmed before use $\left(37^{\circ} \mathrm{C}\right.$ water bath). All glassware items, such as pipettes and bottles, were autoclaved before use, and rinsed with $70 \%$ isopropanol before entering the sterile hood.

\section{2. 11. 1 Cell culture}

InR1G9 cells were grown in $30 \mathrm{ml}$ of complete culture medium on $15-\mathrm{cm}$ plates in $5 \%$ $\mathrm{CO} 2,97 \%$ humidity atmosphere $\left(37^{\circ} \mathrm{C}\right)$ in cell culture incubator (Steri-Kult incubator, Labotect $\mathrm{GmbH}$, Göttingen). Cells were grown to $80-90 \%$ confluency and then propagated as following: plates were washed with $15 \mathrm{ml} 1 \times$ PBS. Next $3 \mathrm{ml}$ of trypsin / EDTA solution were applied to detach the cells. After incubation for $2-3 \mathrm{~min}$ at $37^{\circ} \mathrm{C}$, plates were shaken and cells were washed off from the plate with $10 \mathrm{ml}$ of complete medium and transferred to $50 \mathrm{ml}$ tube. The suspension was centrifuged for $2 \mathrm{~min}$ at 1,300 rpm at RT and the pellet was resuspended in $10 \mathrm{ml}$ complete medium and centrifuged again. The cells were resuspended in $30 \mathrm{ml}$ of complete medium in desired ratio and the suspension was plated out.

\section{2. 11. 2 DEAE-Dextran transfection}

Positively-charged DEAE-dextran forms complexes with negatively-charged DNA which then is taken up by the cells. This method was used to transfect the InR1G9 cells once they reached $80-90 \%$ confluency. The plate was washed with $15 \mathrm{ml}$ of $1 \times$ PBS, then $3 \mathrm{ml}$ of trypsin / EDTA solution was applied. After incubation for $2-3 \mathrm{~min}$ at $37^{\circ} \mathrm{C}$, the plate was shaken to detach the cells. The cells were washed off with medium containing no serum and transferred to $50 \mathrm{ml}$ tube. After centrifugation, the cell pellet was resuspended 
in $10 \mathrm{ml}$ TD Buffer and centrifuged again (washing step). The cell pellet was then resuspended in TD Buffer ( $1 \mathrm{ml}$ TD per $6-\mathrm{cm}$ plate). DEAE-dextran solution ( $5 \mu \mathrm{l}$ per 6 -cm plate) was added to the cell suspension and after gentle mixing it was transferred to $50 \mathrm{ml}$ tubes containing DNA to be transfected. After gentle mixing DNA / cell suspension was incubated for $15 \mathrm{~min}$ at RT to allow DNA uptake and then serum-containing culture medium ( $1 \mathrm{ml}$ per $\mathrm{ml}$ of cell suspension) was added to stop transfection. The cells were centrifuged and washed with complete medium. After final centrifugation, the cells were suspended in culture medium ( $5 \mathrm{ml}$ per $6-\mathrm{cm}$ plate) and plated out. The cells were harvested $48 \mathrm{~h}$ after transfection and luciferase and GFP reporter gene assays were performed. As control for transfection efficiency and squelching, pGFPtpz-cmv was cotransfected (500 ng per 6-cm plate) and total DNA content was kept constant throughout all groups in a given experiment by adding pBluescript.

\section{TD Buffer :}

Tris $\mathrm{pH} 7.4$

$\mathrm{NaCl} \quad 140 \mathrm{mM}$

$\mathrm{KCl} \quad 5 \mathrm{mM}$

$\begin{array}{ll}\mathrm{K}_{2} \mathrm{HPO}_{4} & 0.7 \mathrm{mM}\end{array}$

DEAE-Dextran (M: 500,000): $60 \mathrm{mg} / \mathrm{ml}$ in distilled water and then sterilised by filtration

Insulin solution $(10 \mu \mathrm{M})$ :

$\begin{array}{ll}\text { Porcine insulin } & 3 \mathrm{mg} / 50 \mathrm{ml} \\ \text { BSA } & 100 \mathrm{mg} / 50 \mathrm{ml}\end{array}$

Insulin was dissolved in $0.9 \% \mathrm{NaCl}$ solution $(\mathrm{pH} 2.8)$. The $\mathrm{pH}$ of the solution was neutralized by addition of $1 \mathrm{~N} \mathrm{NaOH}$ and then BSA was added. The aliquots of $1 \mathrm{ml}$ were stored at $-80^{\circ} \mathrm{C}$. Insulin treatment was performed as described in 2. 2. 11. 4.

\section{2. 11. 3 Metafectene transfection}

In order to get high transfection efficiency for further immunoprecipitation experiments, transfection with a polycationic transfection reagent, Metafectene (Biontex, Munich), was performed according to the manufacturer's protocol.

This method was used to transfect the InR1G9 cells once they reached $80-90 \%$ confluency. DNA and Metafectene were separately mixed in the Eppendorf tubes with the 
medium without serum and antibiotics to a final volume of $300 \mu \mathrm{l}$. The plate was washed with $15 \mathrm{ml}$ of $1 \times$ PBS, then $3 \mathrm{ml}$ of trypsin / EDTA solution was applied. After incubation for $2-3 \mathrm{~min}$ at $37^{\circ} \mathrm{C}$, the plate was shaken to detach the cells. The cells were washed with medium containing serum and transferred to a $50 \mathrm{ml}$ tube. After centrifugation, the cell pellet was resuspended in the appropriate amount of culture medium and plated out (4,5 $\mathrm{ml}$ per 6-cm plate). Subsequently, DNA/medium mix was added to the metafectene/medium mix and incubated for $25 \mathrm{~min}$ at RT. The DNA/Metafectene complex was added to the $6 \mathrm{~cm}$ plate.

\section{2. 11. 4 Insulin treatment}

After transfection, the cells were incubated for $24 \mathrm{~h}$ in complete medium. Then the medium was withdrawn and fresh medium without serum, containing BSA and antibiotics, was applied. $23 \mathrm{~h}$ before harvesting insulin was added at a final concentration of $100 \mathrm{nM}$.

\section{2.11.5 Cell extract preparation}

Cells were harvested $48 \mathrm{~h}$ after transfection. The plates were washed once with 2-3 $\mathrm{ml}$ of ice-cold $1 \times$ PBS buffer. $1 \mathrm{ml}$ of scraping buffer was then applied to each 6 -cm plate. The cells were scraped with rubber scraper and the cell suspension was transferred to eppendorf tubes standing on ice. Each plate was rinsed with $0.5 \mathrm{ml}$ of scraping buffer and the suspension was transferred to the same tube. Cells were centrifuged for $5 \mathrm{~min}$, at $6,000 \mathrm{rpm}, 4^{\circ} \mathrm{C}$ (Eppendorf $5415 \mathrm{C}$ ). The cell pellet was resuspended in $150 \mu \mathrm{l}$ of potassium phosphate buffer. Cells were then disrupted by three cycles of freezing and thawing (liquid nitrogen $/ 37^{\circ} \mathrm{C}$ water bath). The lysate was vortexed shortly and centrifuged (5 min, 14,000 rpm, $4^{\circ} \mathrm{C}$ ). The cleared lysate was directly used for the luciferase or the GFP reporter gene assay.

\section{Scraping buffer:}

$\begin{array}{ll}\text { Tris } \mathrm{pH} 7.5 & 40 \mathrm{mM} \\ \mathrm{NaCl} & 150 \mathrm{mM} \\ \text { EDTA }(\mathrm{pH} \mathrm{8.0)} & 1 \mathrm{mM}\end{array}$


Potassium Phosphate Buffer $(\mathrm{pH} 7.8)$ :

$\mathrm{K}_{2} \mathrm{HPO}_{4}$

$100 \mathrm{mM}$

$\mathrm{KH}_{2} \mathrm{PO}_{4}$

$100 \mathrm{mM}$

\section{2.11. 6 Luciferase reporter gene assay}

Firefly luciferase enzyme catalyses oxydative decarboxylation of luciferine. This reaction is dependent on $\mathrm{Mg}^{2^{+}}$ions and ATP and apart from AMP, $\mathrm{CO}_{2}$ and oxyluciferine, photons are produced. In the linear range, light emission depends on the luciferase concentration. Therefore, the luminometric measurement allows to estimate the expression level of the luciferase reporter gene. For the luciferase assay, $50 \mu \mathrm{l}$ of cell extract was taken and mixed with $368 \mu \mathrm{l}$ of assay mix in luminometric tubes (Sarstedt, Nümbrecht). Tubes were vortexed and placed in a luminometer (AutoLumat LB 953, E\&G Berthold, Wildbach) where to each tube luciferin mix was injected and light emission at $560 \mathrm{~nm}$ was measured for $20 \mathrm{sec}$. One tube containing only luciferin mix served as reference sample to estimate background level.

Assay Mix:

Potassium Phosphate Buffer

$16.5 \mathrm{mM}$

Glycylglycine Buffer

$82,4 \%(\mathrm{v} / \mathrm{v})$

DTT

$1 \mathrm{mM}$

ATP

$2 \mathrm{mM}$

Luciferine Mix in Glycylglycine Buffer:

$\begin{array}{lr}\text { Luciferine } & 1 \mathrm{mM} \\ \text { DTT } & 10 \mathrm{mM}\end{array}$

Glycylglycine Buffer:

Glycylglycine (pH 7.8) 25 mM

$\mathrm{MgSO}_{4} \quad 15 \mathrm{mM}$

EGTA $4 \mathrm{mM}$ 


\section{2. 11. 7 GFP reporter gene assay}

The Green Fluorescent Protein (GFP) mutant (tpz) used in the assay is derived from jelly fish (Aequoria victoria). When irradiated with ultraviolet light, GFP protein possesses capability of emission of green light (fluorescent absorption/emission) which is proportional to its concentration. In this work a GFP construct was used which is under the control of a constitutive cytomegalovirus promoter (pGFPtpz-cmv). Transfection of this GFP construct served as a control for transfection efficiency and to monitor squelching (non-specific inhibition of luciferase reporter gene activity due to titration of transcriptional factors by co-transfected expression constructs). For GFP assay, $50 \mu$ of cell extracts were taken and pipetted into microplate (96K, Greiner $\mathrm{GmbH}$, Frickenhausen). Microplates were read by Fusion ${ }^{\mathrm{TM}}$ (Packard) with excitation/emission wavelengths of 485 $\mathrm{nm}$ and $530 \mathrm{~nm}$, respectively.

\section{2. 12 Software}

Restriction site mapping was performed using NEBcutter application (New England Biolabs, www.neb.com).

DNA and protein sequence analysis and database searching was performed using online software located at www.expasy.ch or various others internet sites.

Statistical analysis and plotting of graphs was performed using Microsoft Excel 2003 Software.

Sequence analysis and BLAST (Basic Local Alignment Search Tool) search were done using Chromas software tool (Technelysium Pty Ltd., Austria). 


\section{Results}

\section{1 Constructs, prepared in this study}

The constructs which were prepared in this study are summarized below in the Table 6. All of these constructs were verified by sequencing. The detailed description of the cloning strategies is presented in the "Materials and Methods" section 2. 1. 10.

\begin{tabular}{|c|c|}
\hline Construct & Description \\
\hline 1) GST-CBP(2040-2170) & $\begin{array}{l}\text { Amino acids } 2040 \text { to } 2170 \text { of CBP } \\
\text { with N-terminally fused GST tag }\end{array}$ \\
\hline 2) GST-CBP(2160-2305) & $\begin{array}{l}\text { Amino acids } 2160 \text { to } 2305 \text { of CBP } \\
\text { with N-terminally fused GST tag }\end{array}$ \\
\hline 3) GST-CBP(2300-2441) & $\begin{array}{l}\text { Amino acids } 2300 \text { to } 2441 \text { of CBP } \\
\text { with N-terminally fused GST tag }\end{array}$ \\
\hline 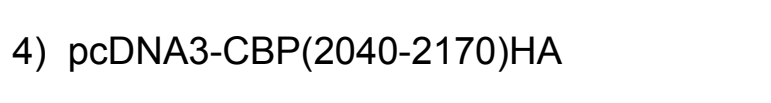 & $\begin{array}{l}\text { Amino acids } 2040 \text { to } 2170 \text { of CBP } \\
\text { with C-terminally fused HA tag }\end{array}$ \\
\hline 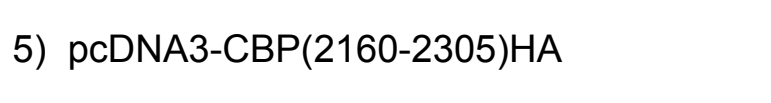 & $\begin{array}{l}\text { Amino acids } 2160 \text { to } 2305 \text { of CBP } \\
\text { with C-terminally fused HA tag }\end{array}$ \\
\hline 6) $\mathrm{pcDNA3-CBP}(2300-2441) \mathrm{HA}$ & $\begin{array}{l}\text { Amino acids } 2300 \text { to } 2441 \text { of CBP } \\
\text { with C-terminally fused HA tag }\end{array}$ \\
\hline 7) GST-CBP(2300-2441)S2420A & $\begin{array}{l}\text { Amino acids } 2040 \text { to } 2170 \text { of CBP; } \\
\text { serine- } 2420 \text { mutated to alanine }\end{array}$ \\
\hline 8) GST-CBP(2300-2441)S2424A & $\begin{array}{l}\text { Amino acids } 2160 \text { to } 2305 \text { of CBP; } \\
\text { serine- } 2424 \text { mutated to alanine }\end{array}$ \\
\hline 9) GST-CBP(2300-2441)S2420A/S2424A & $\begin{array}{l}\text { Amino acids } 2300 \text { to } 2441 \text { of CBP; } \\
\text { serine-2420 mutated to alanine } \\
\text { and serine-2424 mutated to } \\
\text { alanine }\end{array}$ \\
\hline 10) Gal4-CBP(2040-2441)S2420A & $\begin{array}{l}\text { N-terminally fused DNA-binding } \\
\text { domain GAL4 (amino acids 1-147) }\end{array}$ \\
\hline 11) Gal4-CBP(2040-2441)S2424A & $\begin{array}{l}\text { N-terminally fused DNA-binding } \\
\text { domain GAL4 (amino acids 1-147) }\end{array}$ \\
\hline 12) Gal4-CBP(2040-2441)S2420A/S2424A & $\begin{array}{l}\text { N-terminally fused DNA-binding } \\
\text { domain GAL4 (amino acids 1-147) }\end{array}$ \\
\hline
\end{tabular}

Table 6. List of the constructs, prepared in this study 


\section{2 GSK3 $\beta$-induced phosphorylation of C-terminal fragments of CBP in vitro}

A schematic representation of $\mathrm{CBP}$ and $\mathrm{CBP}$ fragments, which were used for in vitro kinase assay is given in Fig. 8.

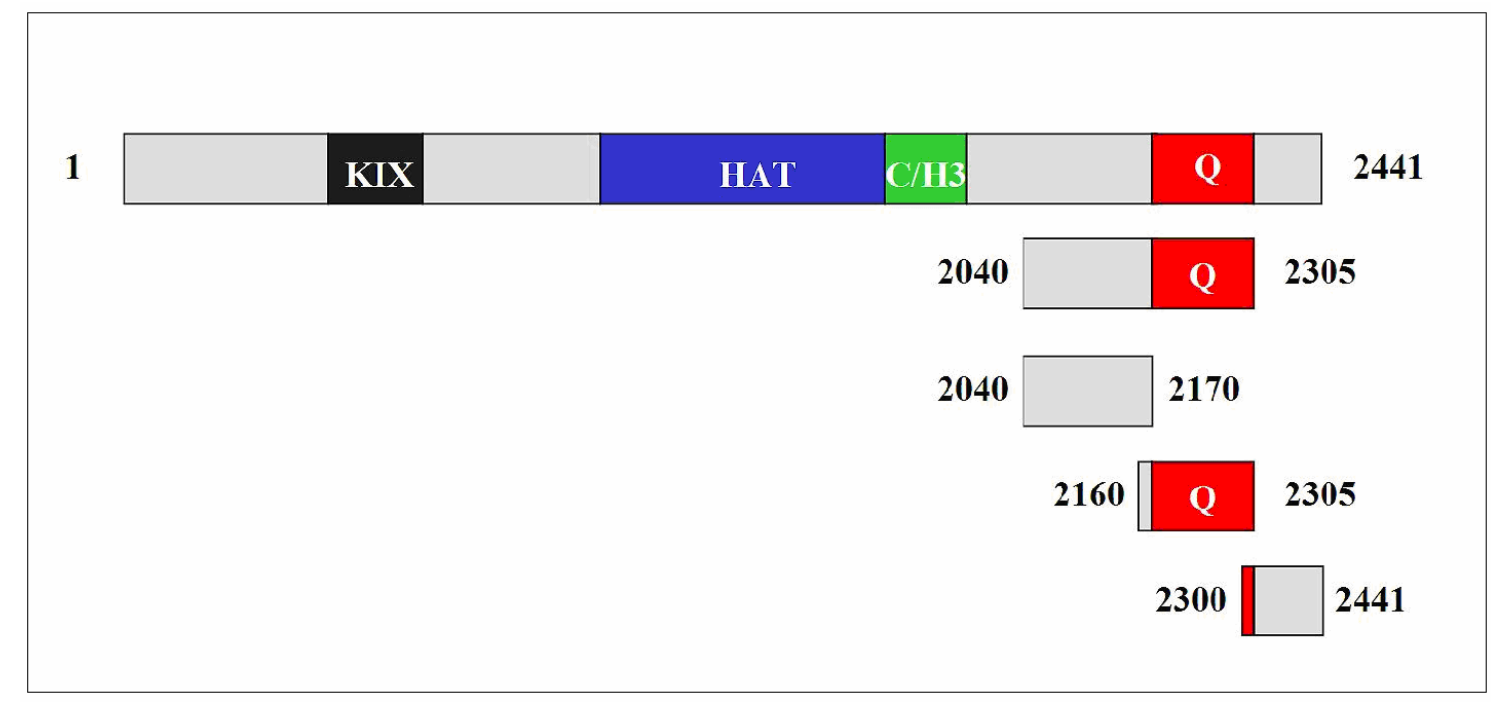

Fig. 8. Full-length CBP (Cyclic AMP response element-binding protein (CREB) binding protein) and four C-terminal fragments examined in this study

The CBP fragments were generated by PCR from cDNA encoding full length CBP and further subcloned into the pGEX-2T vector into the BamHI restriction site.

Most of the GSK3 $\beta$ substrates require prior phosphorylation in order to be further phosphorylated by GSK3 $\beta$ (Cohen and Frame, 2001). Recent results of this lab indicated that GSK3ß is able to efficiently phosphorylate GST-CBP(2040-2305) fusion protein in vitro without prephosphorylation (Dimopoulos N., PhD Thesis, 2003). Based on these data, three GST-CBP fusion proteins containing the amino acids 2040 to 2170 , the amino acids 2160 to 2305, and the amino acids 2300 to 2441 were prepared. The proteins of interest were overexpressed in bacteria and affinity purified with glutathione crosslinked on agarose beads. The in vitro kinase assay was performed by incubation of the GSTCBP fusion proteins coupled to the agarose beads with recombinant GSK3 $\beta$ (New England Biolabs, USA) in the presence of radioactively labelled $\mathrm{Y}^{32} \mathrm{P}$-ATP (GE Healthcare, UK). After kinase assay, the proteins bound to the beads, were extensively washed and the proteins were loaded on a SDS-PAGE gel and stained with Coomassie Blue. After destaining, the gel was dried under vacuum and subjected to autoradiography. Staining with Coomassie Blue was used to control protein amounts and thus exclude the possibility of obtaining incorrect autoradiography data due to different proten loading. Calculated sizes of GST-CBP fusion proteins are $56 \mathrm{kDa}$ (GST-CBP(2040-2305)), $41 \mathrm{kDa}$ (GST-CBP(2040-2170)), 43 kDa (GST-CBP(2160-2305)) and 43 kDa (GST-CBP(2300- 
2441)), respectively. The size of GST protein, which served as a negative control, is 26 kDa. All GST-fused proteins and GST migrated according to the expected size. Faster migrating bands represent different GST-containing proteins obtained due to photolytic activity in bacteria during purification (Fig. 9A).

As revealed by autoradiography (Fig. 9B), recombinant GSK3 $\beta$ phosphorylated GSTCBP(2040-2305), GST-CBP(2040-2170), GST-CBP(2160-2305) and GST-CBP(23002441). The relative phosphorylation by GSK3 $\beta$ was $95 \pm 9 \%$ for GST-CBP(2040-2170), $152 \pm 5 \%$ for GST-CBP(2160-2305) and $435 \pm 66 \%$ for GST-CBP(2300-2441), compared to GST-CBP(2040-2305), which was set to $100 \%$ (Fig. 10). The negative control GST was not phosphorylated (Fig 9B).

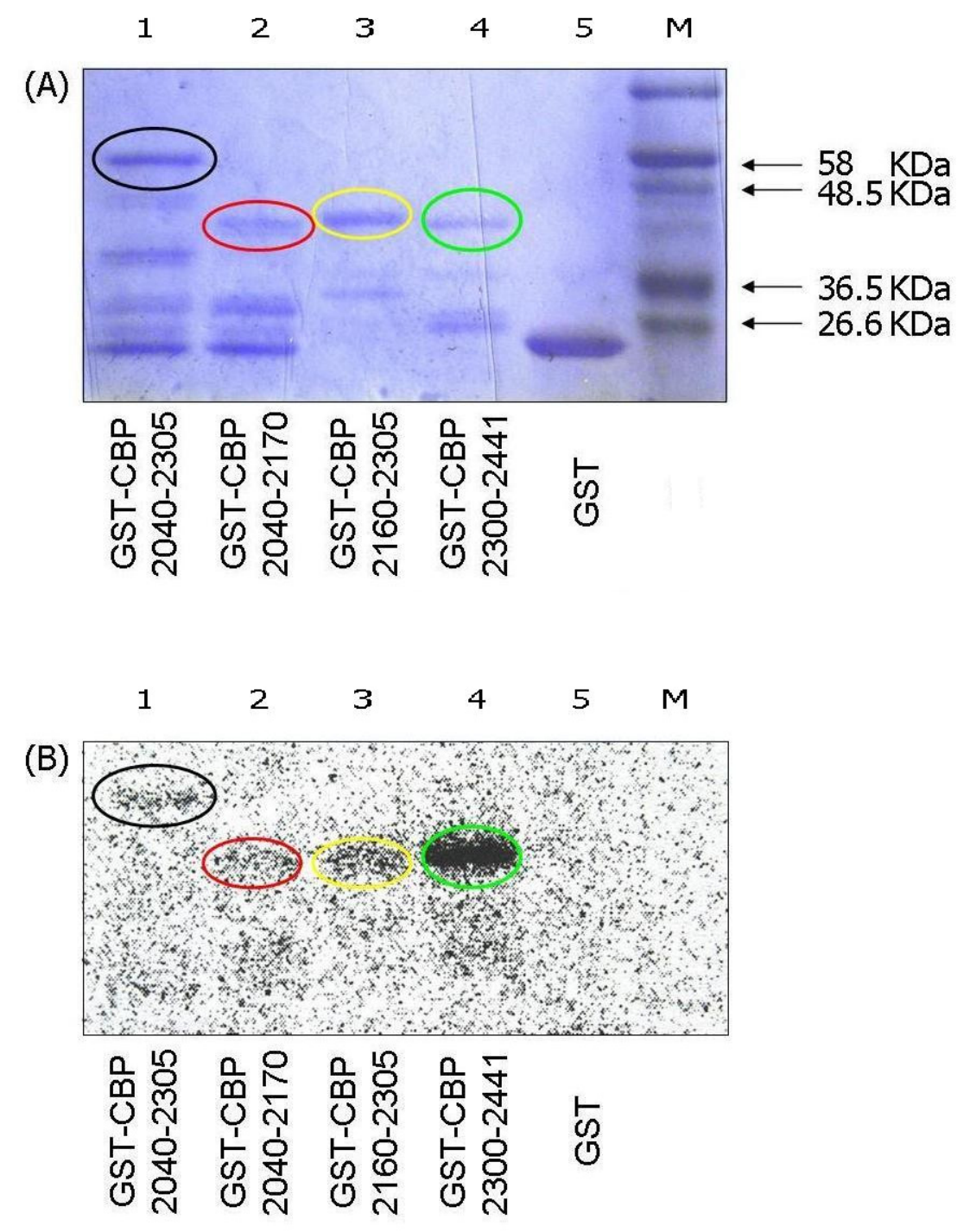

Fig. 9. Recombinant GSK3 $\beta$ phosphorylation of CBP fusion proteins in vitro

(A) Coomassie stained gel of GST-CBP fusion proteins (lanes 1-4). Negative control is represented by GST (lane 5). $3 \mu \mathrm{g}$ of the bacterially expressed GST-CBP(2040-2305) (lane 1), GST-CBP(2040-2170) (lane 2), GST-CBP (2160-2305) (lane 3), GST-CBP (2300-2441) (lane 4) and GST (lane 5) proteins were incubated with the recombinant GSK3 $\beta$ in the presence of radioactively labelled $\mathrm{y}^{-32}{ }^{32}$-ATP. The reaction was stopped by 
adding $2 X$ SDS sample buffer and the samples were loaded on SDS-PAGE gel, stained with coomassie and destained.

(B) Autoradiography of the same gel as in (A). GST-CBP fusion proteins; GST-CBP (2040-2305) (lane 1), GST-CBP(2040-2170) (lane 2), GST-CBP(2160-2305) (lane 3), GST-CBP(2300-2441) (lane 4) and GST (lane 5), M - molecular weight marker. A typical result from three independent experiments is shown. GST - Glutathione S-Transferase, M - protein weight marker.

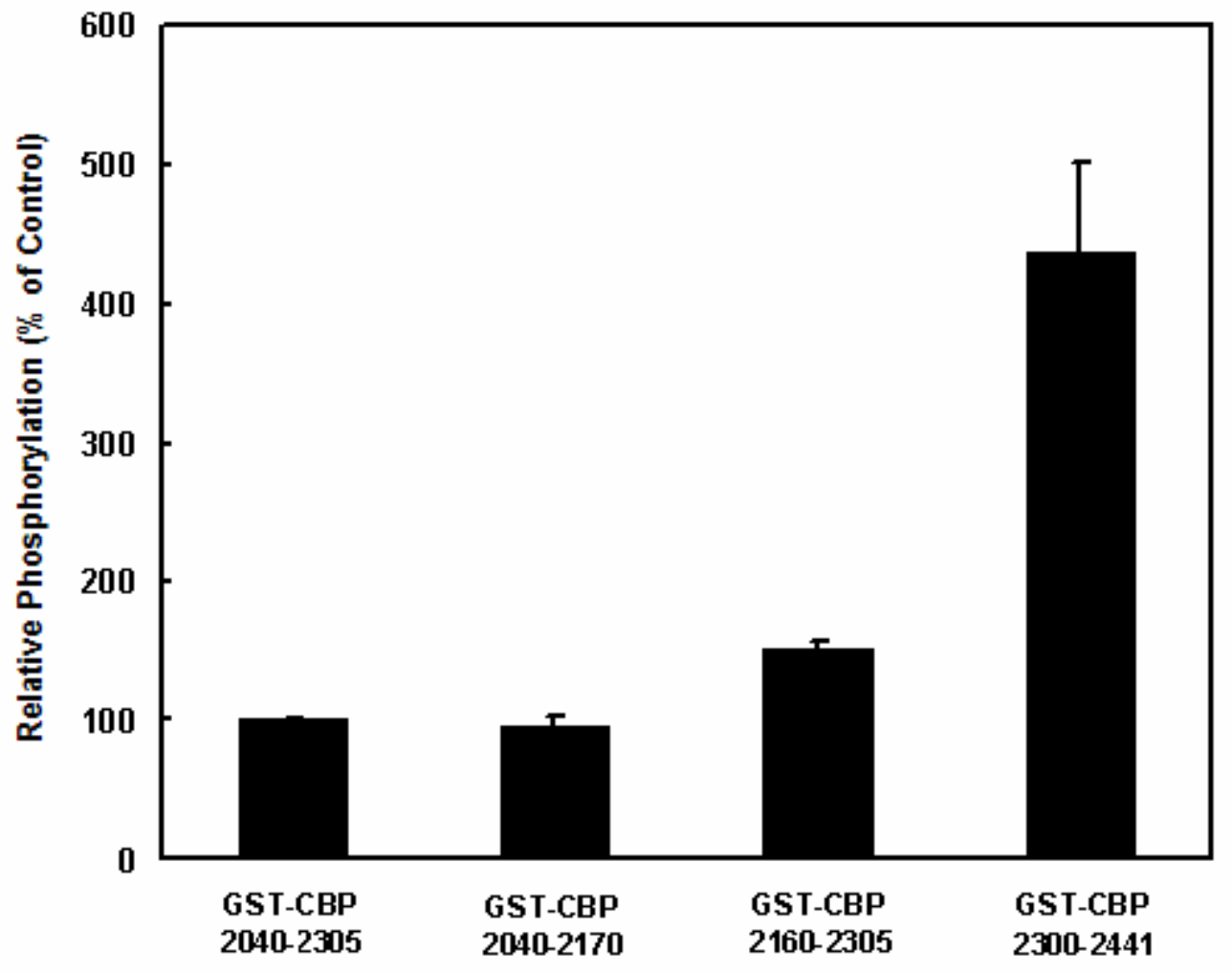

Fig. 10. Relative phosphorylation of GST-CBP fusion proteins by recombinant GSK3 $\beta$ in vitro

$3 \mu \mathrm{g}$ of the GST-CBP fusion proteins GST-CBP(2040-2305), GST-CBP(2040-2170), GSTCBP(2160-2305), GST-CBP(2300-2441) and the negative control GST (not shown) were incubated with the recombinant GSK3 $\beta$ in the presence of radioactively labelled $\mathrm{Y}^{-32} \mathrm{P}$ ATP. The samples were resolved on SDS-PAGE gel, stained with coomassie, destained and subjected to autoradiography. After autoradiography the data were analyzed by phosphoimager. Relative phosphorylation compared to GST-CBP(2040-2305), which was set to $100 \%$ in each experiment. Values are means $\pm \mathrm{S}$. E. of three independent experiments.

\section{3 Immunoprecipitation of HA-tagged CBP proteins expressed in InR1G9 cells}

The HA-tag is a peptide sequence (YPYDVPDYA) derived from the human influenza virus hemagglutinin protein (Wilson et al., 1984). It can be detected with anti-HA antibodies on Western blots and used for immunoprecipitation. 
In order to investigate possible phosphorylation events of CBP in vivo, CBP fragments, containing the aa 2040 to 2170 , the aa 2160 to 2305 and the aa 2300 to 2441 , were extended C-terminally with the HA-epitope tag and subcloned into the CMV-driven vector pcDNA3 into the EcoRV and Xbal restriction sites (described in 2.1.10). Immunoprecipitation efficiency was controlled by immunoblotting with the same anti-HA antibody which was used for immunoprecipitation. Immunoprecipitation efficiency was estimated to be close to $100 \%$ (Fig. 11).

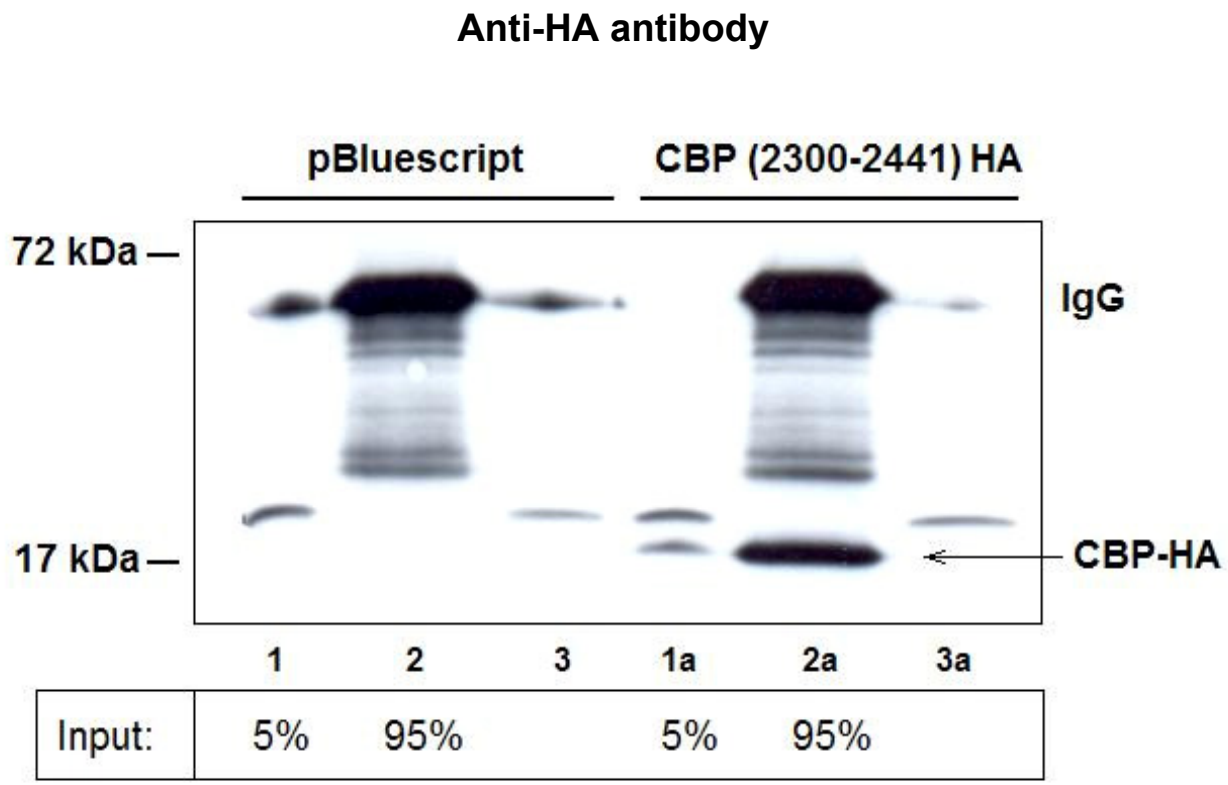

Fig. 11. Immunoprecipitation of HA-tagged CBP(2300-2441)

InR1G9 cells were transiently transfected with pcDNA3-CBP(2300-2441)HA (3.5 $\mu$ g per 6$\mathrm{cm}$ dish ) using metafectene (Biontex, Germany). pBluescript vector (Stratagene, USA) served as a negative control. A $5 \%$ reference sample was taken from the cell lysate after incubation with the HA-antibody (lanes 1 and 1a) as well as a $95 \%$ sample of the immunoprecipitate (lanes 2 and $2 a$ ). Lanes 3 and $3 a$ represent samples taken from the supernatants after incubation of the cell lysates with the Protein A agarose beads.

\section{4 Studies on the phosphorylation of CBP(2300-2441) in InR1G9 cells using anti-} P-Ser/anti-P-Thr antibodies, under basal conditions, under insulin treatment, and under cotransfection of GSK3 $\beta$ or a kinase-dead GSK3 $\beta$ mutant

Since GSK3 $\beta$ is a serine/threonine directed kinase (Frame and Cohen, 2001), we decided to use, as a first approach, an antibody which is able to specifically recognize phosphorylated serine and threonine residues (Yan et al., 1998; Pawson et al., 1997). Thus, for the initial series of experiments a monoclonal antiphosphoserine/threonine antibody was used. InR1G9 cells were transiently cotransfected with the expression vector, encoding $\mathrm{CBP}(2300-2441) \mathrm{HA}$ either with GSK3 $\beta$ wild type or its inactive "kinase 
dead" mutant, GSK3 $\beta$ R85A (see 2.1.10 for details). An empty vector, pBluescript, served as a negative control. $24 \mathrm{~h}$ after transfection the medium was changed to medium without serum and $1 \mathrm{~h}$ later, were indicated, cells were treated with $100 \mathrm{nM}$ insulin as indicated. Since GSK3 $\beta$ might phosphorylate CBP in vivo and insulin is well known to inhibit GSK3 $\beta$, insulin may decrease the phosphorylation of CBP-HA. The immunoprecipitation of CBP$\mathrm{HA}$ was controlled by immunoblotting with anti-HA antibody (Fig. 12A) and the phosphorylation was examined by immunoblotting with antiphosphoserine/threonine antibody (Fig. 12B). A representative western blot shows that cotransfection of GSK3 $\beta$ and the "kinase dead" mutant GSK3 $\beta$ R85A leads to a slight decrease in the $\operatorname{CBP}(2300$ 2441)HA expression level, while insulin treatment enhanced the CBP-HA expression. As shown in Fig. 12B and in a series of experiments performed under different conditions, we were unable to detect a phosporylation using the anti-P-Ser/anti-P-Thr antibody.

Since forskolin promotes the phosphorylation of serine-133 within CREB through translocation of protein kinase A to the nucleus (Hagiwara et al., 1993; Harootunian, et al., 1993), it provides the possibility to use phosphorylated CREB as a positive control for antiphosphoserine antibodies.

InR1G9 cells were transiently transfected with an expression vector encoding $\mathrm{CBP}(2300$ 2441)HA together with GSK3 $\beta$ wild type (see 2.1.10 for details). The empty vector pBluescript served as a negative control. Additionally, C-terminally tagged HA-CREB, was transfected. Insulin treatment and the immunoprecipitation procedure were done as described above. CREB phosphorylation was induced by forskolin treatment $(10 \mu \mathrm{M}) 30$ min before cell harvesting. As shown in Fig. 13B, no phosphorylation of CBP(2300-2441) or CREB was detected by the anti-P-Ser antibody used.

In order to test the antiphosphoserine and antiphosphothreonine antibodies, in vitro kinase assays were performed. CREB is known to be phosphorylated by PKA on Ser-133 with subsequent phosphorylation by GSK3 $\beta$ on Ser-129. Bacterially expressed GST-CREB was subjected in vitro to phosphorylation by PKA and GSK3 $\beta$. Samples were loaded on a SDS-PAGE gel followed by immunoblotting with an antibody, which recognizes phosphorylated serine-133 within CREB, and with the antiphosphoserine antibody. Phosphoserine-BSA was used as a positive control. As shown in Fig. 14, the antiphosphoserine antibody did not recognize the phosphorylated CREB, akthough phosphorylated CREB was detected by the antiphosphoCREB-S133(P) antibody.

Bacterially expressed GST-CBP(2300-2441) was subjected to the in vitro kinase assay with recombinant GSK3 $\beta$. Samples were loaded on a SDS-PAGE gel followed by the immunoblotting with antiphosphoserine and antiphosphothreonine antibodies. Phosphoserine-BSA and phosphothreonine-BSA served as controls. As shown in Fig. $14 \mathrm{~B}$, none of these antibodies was able to recognize phosphorylated CBP. 

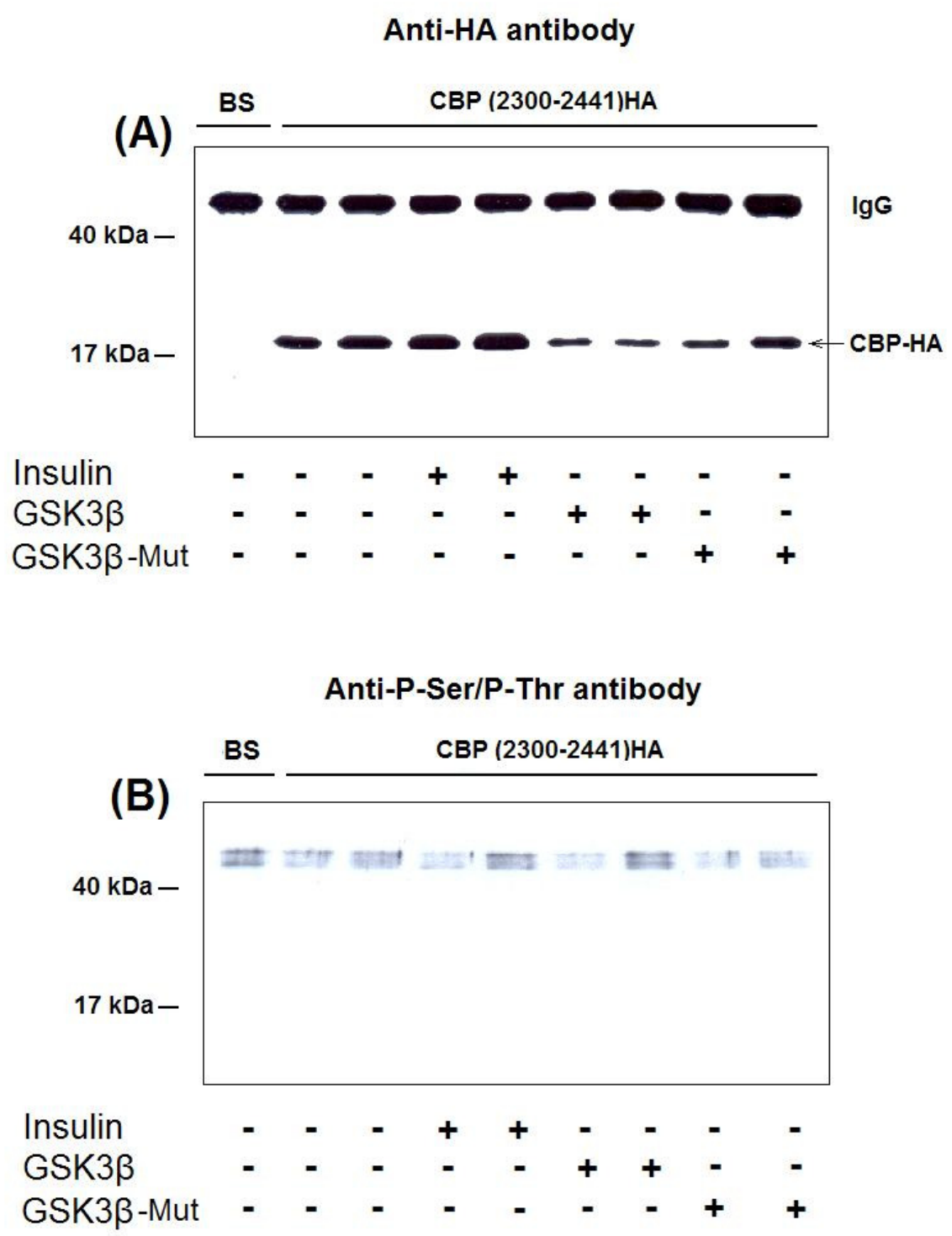

Fig. 12. Studies on the phosphorylation of $\mathrm{CBP}(2300-2441) \mathrm{HA}$ in vivo using anti-P-

\section{Ser/anti-P-Thr antibody}

InR1G9 cells were transiently transfected with pcDNA3-CBP(2300-2441)HA (3.5 $\mu \mathrm{g}$ per $6-\mathrm{cm}$ dish ) using metafectene (Biontex, Germany) together with or without GSK3 $\beta$ wild type or the kinase-dead GSK3 $\beta$ mutant (1.5 $\mu \mathrm{g}$ per $6-\mathrm{cm}$ dish). pBluescript vector (Stratagene, USA) served as a negative control. $24 \mathrm{~h}$ after transfection the medium was changed to medium without serum and $1 \mathrm{~h}$ later, where indicated, cells were treated with $100 \mathrm{nM}$ insulin. After immunoprecipitation with anti-HA antibody, the samples were divided into 2 parts for immunoblotting with anti-HA antibody (A) or anti-P-Ser/anti-P-Thr (BD Transduction Laboratories) antibody (B). 

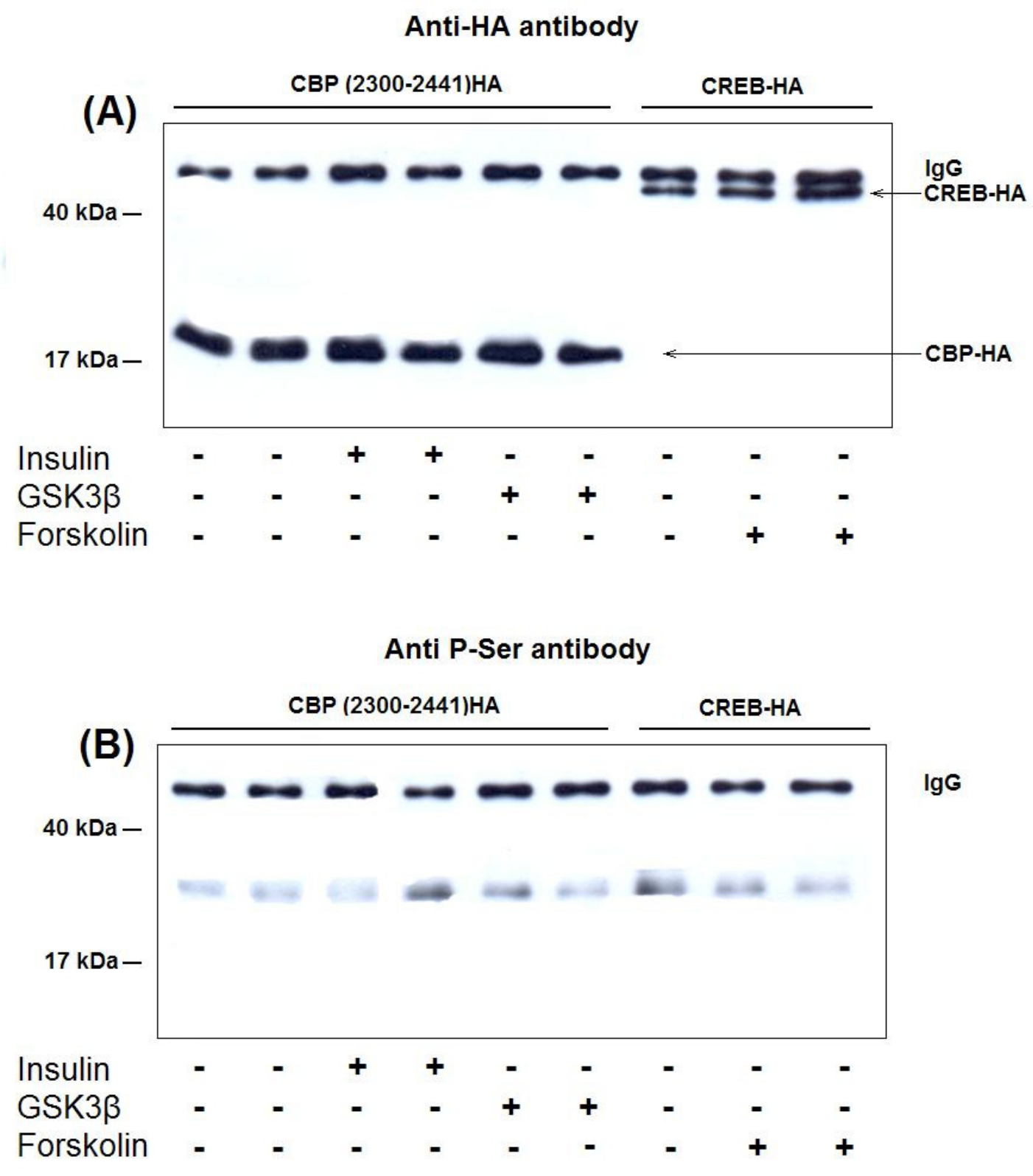

Fig. 13. Studies on the phosphorylation of CBP(2300-2441)HA and CREB-HA in vivo using an antiphosphoserine antibody

InR1G9 cells were transiently transfected with pcDNA3-CBP(2300-2441)HA (3.5 $\mu \mathrm{g}$ per 6$\mathrm{cm}$ dish ) using metafectene (Biontex, Germany) with or without GSK3 $\beta$ wild type $(1.5 \mu \mathrm{g}$ per 6 -cm dish ). CREB-HA ( $5 \mu \mathrm{g}$ per $6-\mathrm{cm}$ dish) served as a positive control. $24 \mathrm{~h}$ after transfection the medium was changed to medium without serum and $1 \mathrm{~h}$ later indicated samples were treated with $100 \mathrm{nM}$ insulin. $30 \mathrm{~min}$ before harvesting, when indicated, cells were treated with $10 \mu \mathrm{M}$ forskolin. After immunoprecipitation with anti-HA antibody, the samples were divided into 2 parts for immunblotting with anti-HA antibody (A) or antiphosphoserine antibody (Zymed Laboratories) (B). 
(A)

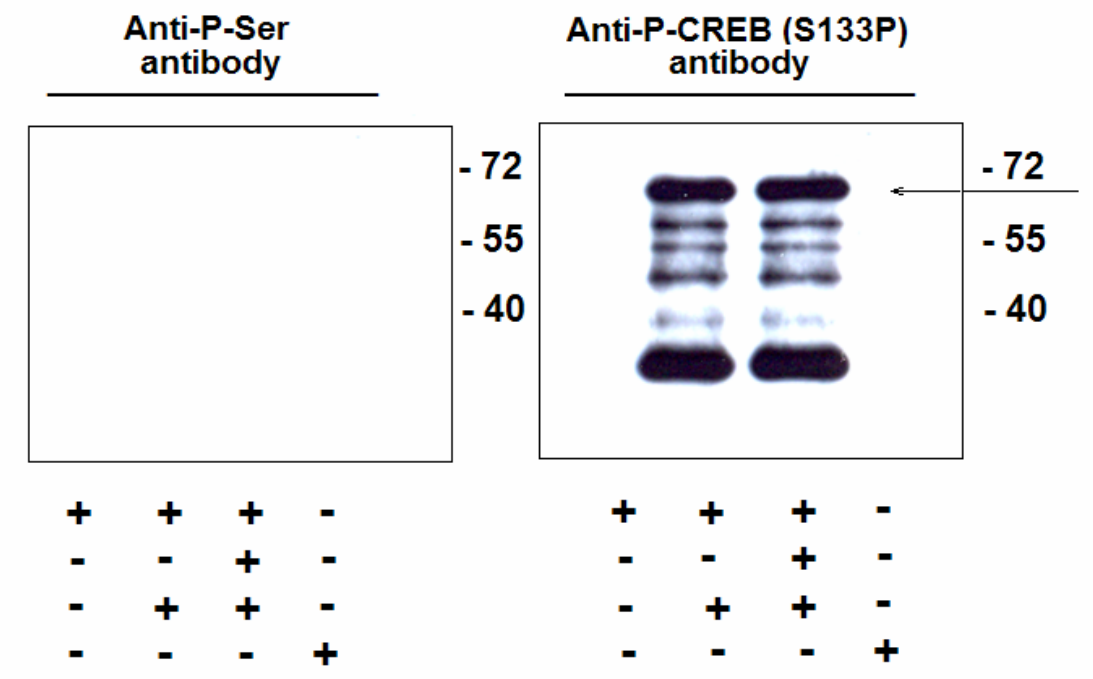

(B)

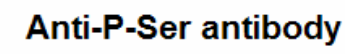

Anti-P-Thr antibody

GST-CREB

GSK3 Beta

Protein Kinase A

P-Ser-BSA
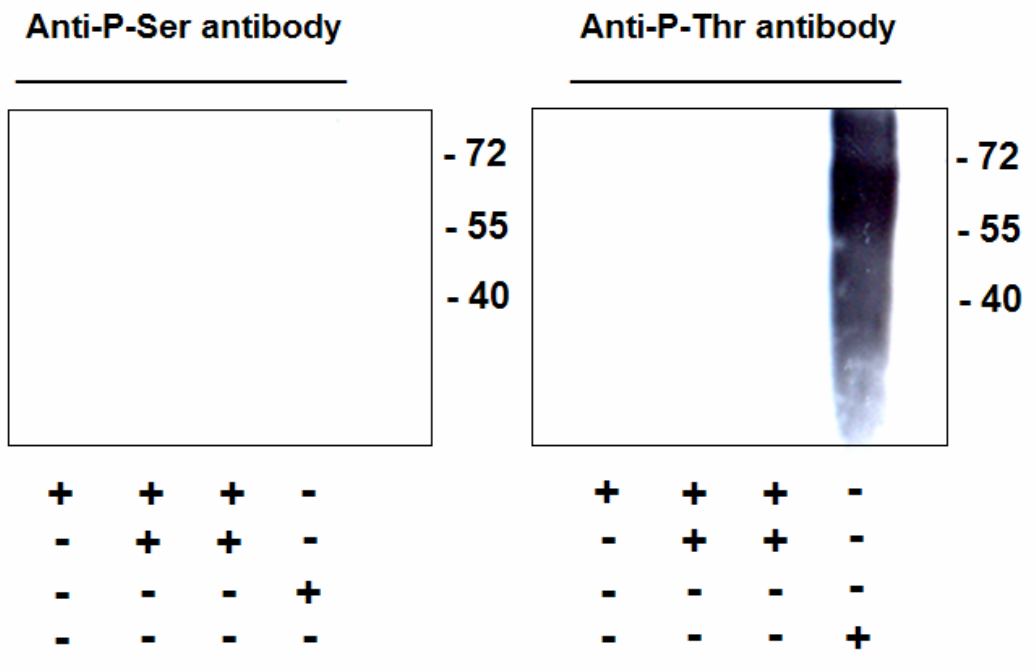

Fig. 14. Control of the antiphosphoserine and antiphosphothreonine antibodies

(A) $3 \mu \mathrm{g}$ of bacterially expressed GST-CREB was incubated in vitro in the presence of ATP with either recombinant protein kinase $A$ or recombinant protein kinase $A+G S K 3 \beta$. The reaction was stopped by adding $2 X$ SDS sample buffer and the samples were loaded on SDS-PAGE gel and immunoblotted. BSA containing phosphorylated serine (P-SerBSA) served as positive control. Left, immunoblot with antiphosphoserine antibody (Zymed Laboratories). Right, immunoblot with antiphosphoCREB (Ser-133 phosphorylated) antibody. The band, representing phosphorylated CREB is highlighted with arrow.

(B) $3 \mu \mathrm{g}$ of bacterially expressed GST-CBP(2300-2441) protein was incubated in vitro in the presence of ATP with recombinant GSK3 $\beta$. The reaction was stopped by adding $2 X$ SDS sample buffer and the samples were loaded on an SDS-PAGE gel and immunoblotted. BSA containing phosphorylated serine (P-Ser-BSA) and BSA containing phosphorylated threonine ( $\mathrm{P}$-Thr-BSA), served as positive controls. Left, immunoblot with antiphosphoserine antibody (Zymed Laboratories). Right, immunoblot with antiphosphothreonine antibody (Sigma). 


\section{5 MALDI-TOF analysis of GST-tagged CBP proteins}

The basic principle of the matrix-assisted laser desorption/ionisation (MALDI) time-of-flight (TOF) mass spectrometry for phosphoprotein identification is a mass difference of 79.983 $\left(\mathrm{HPO}_{3}\right.$ ) (or multiples) between the phosphorylated and non-phosphorylated forms of a protein, or a change in mass of a peptide after digestion with alkaline phosphatase (Yan et al, 1998). Due to its limitations, it is possible to apply MALDI-TOF analysis only to peptides with less than $3000 \mathrm{Da}$. Exceeding this value will result in a decrease of the accuracy of the analysis. In order to analyze proteins with a higher molecular weight, a proteolytic cleavage must be performed. Usually, for this purpose, an extra pure trypsin is used. The limitation of enzyme utilization arises from the enzyme's nature - it cleaves the substrate only if specific cleavage sites, which are individual for each enzyme, are present within the polypeptide sequence. Trypsin, for example, cleaves a protein after every lysine or argnine. Therefore, in the absence of them in a protein sequence it is not possible to obtain protein fragments. In this case, enzymes a combination of enzymes with different cleavage sites must be used.

In a series of experiments, we subjected GST-fused CBP proteins first to in vitro kinase assay with GSK3 $\beta$ followed by in-gel trypsin digestion of the excised band, containing the GST-CBP fusion protein, from the coomassie-stained gels with further MALDI-TOF analysis. The following proteins were analyzed: GST-CBP(2040-2170) (Fig. 15) and GSTCBP(2300-2441) (Figs. 16, 17). Since the previous experiments showed that protein GSTCBP(2300-2441) was most heavily phosphorylated in vitro, it was analyzed also using trypsin cleavage followed by $\mathrm{CNBr}$ cleavage (Fig. 17). This was done in order to perform more precise analysis. As revealed by the direct overlay of spectrum $(A)$, which belongs to the nonphosphorylated (control) sample, with spectrum (B), which represents the sample, incubated with GSK3 $\beta$, in corresponding figures, no significant differences in peptide masses were detected (Figs 15-17). 

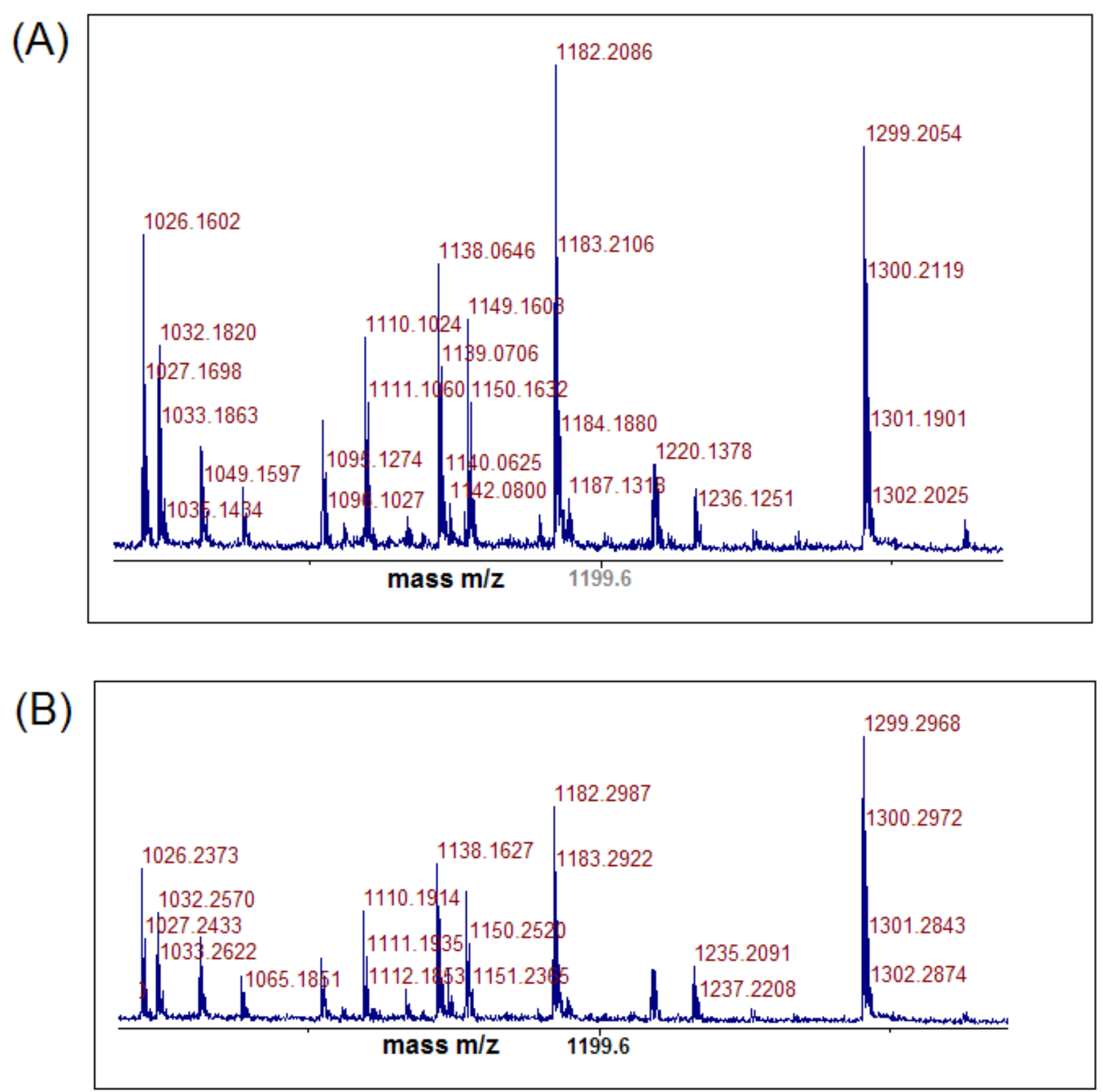

Fig. 15. MALDI-TOF spectrum of the GST-CBP(2040-2170) with (B) and without (A) in vitro phosphorylation by GSK3 $\beta$ followed by trypsin digestion

Bacterially expressed GST-CBP(2040-2170) (3 $\mu \mathrm{g})$ was subjected to in vitro phosphorylation by recombinant GSK3 3 . After staining of the SDS-PAGE gel with Coomassie, the band, containing GST-CBP(2040-2170), was excised, digested with trypsin and subjected to MALDI-TOF analysis.

(A) Spectrum of GST-CBP(2040-2170) without incubation with recombinant GSK3 $\beta$.

(B) Spectrum of GST-CBP(2040-2170) incubated with recombinant GSK3 $\beta$. 

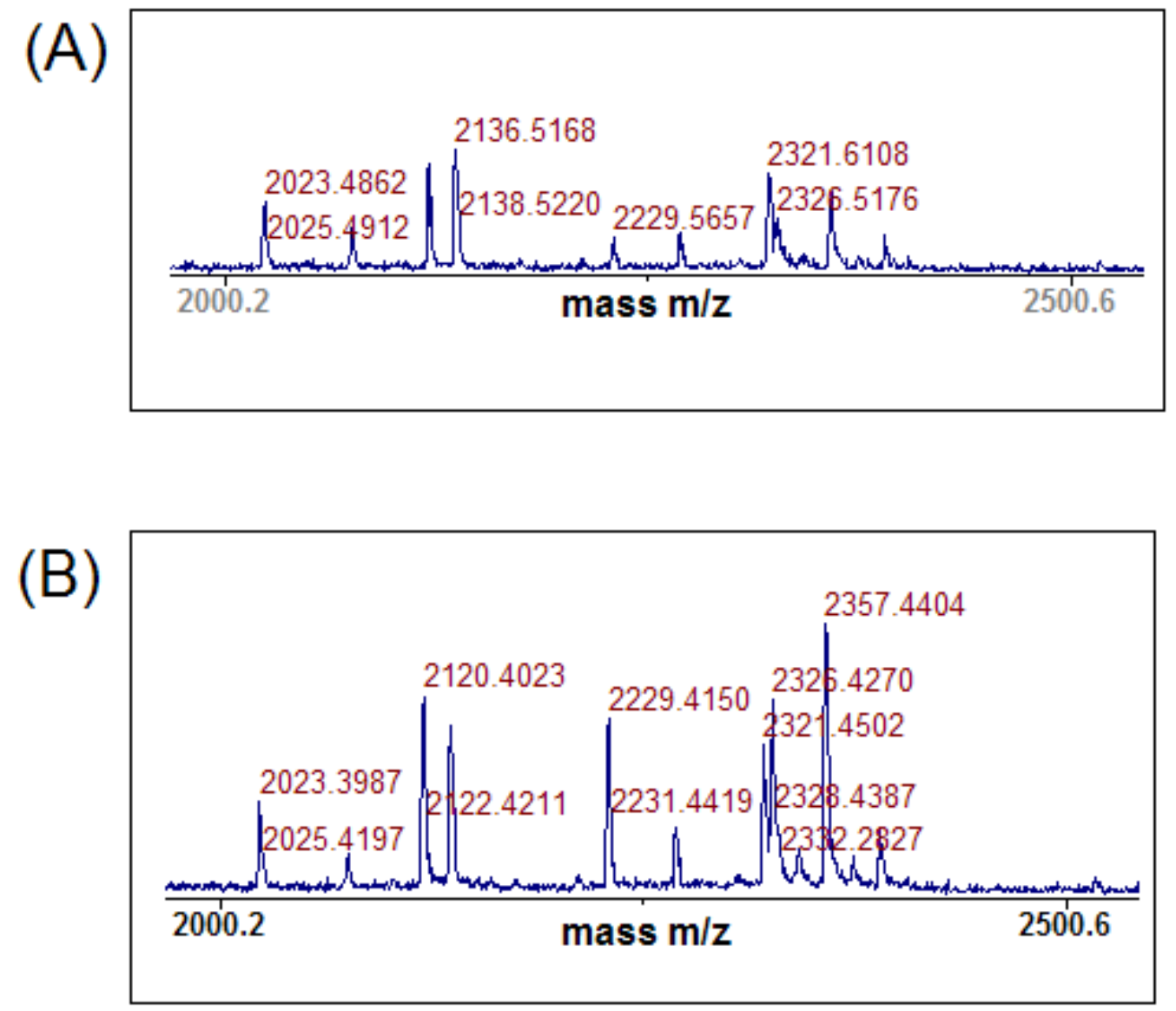

Fig. 16. MALDI-TOF spectrum of the GST-CBP(2300-2441) with (B) and without (A) in vitro phosphorylation by GSK3 $\beta$ followed by trypsin digestion

Bacterially expressed GST-CBP(2300-2441) (3 $\mu \mathrm{g})$ was subjected to in vitro phosphorylation by recombinant GSK3 3 . After staining of the SDS-PAGE gel with Coomassie, the band, containing GST-CBP(2300-2441), was excised, digested with trypsin and subjected to MALDI-TOF analysis.

(A) Spectrum of GST-CBP(2300-2441) without incubation with recombinant GSK3 $\beta$.

(B) Spectrum of GST-CBP(2300-2441) incubated with recombinant GSK3 $\beta$. 
(A)

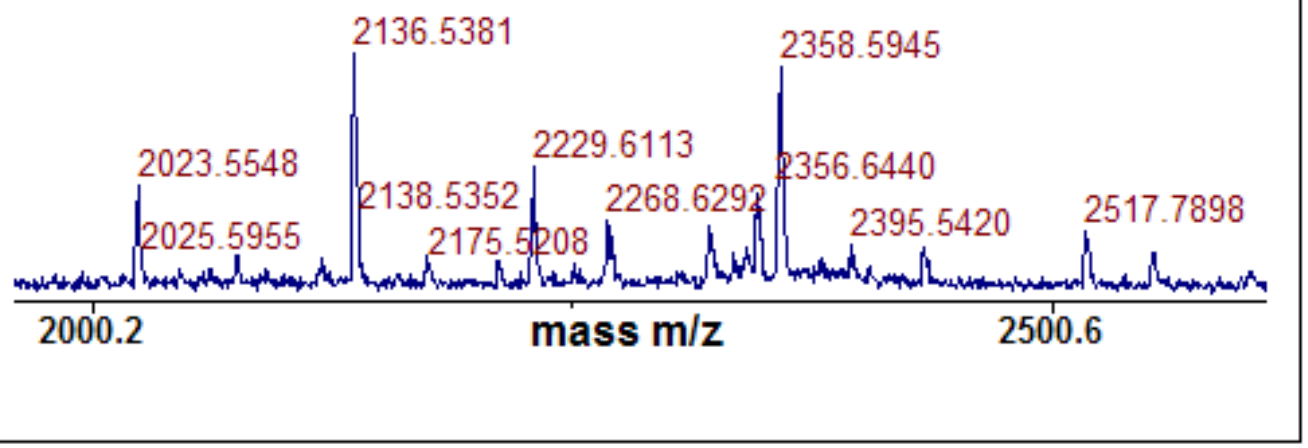

(B)

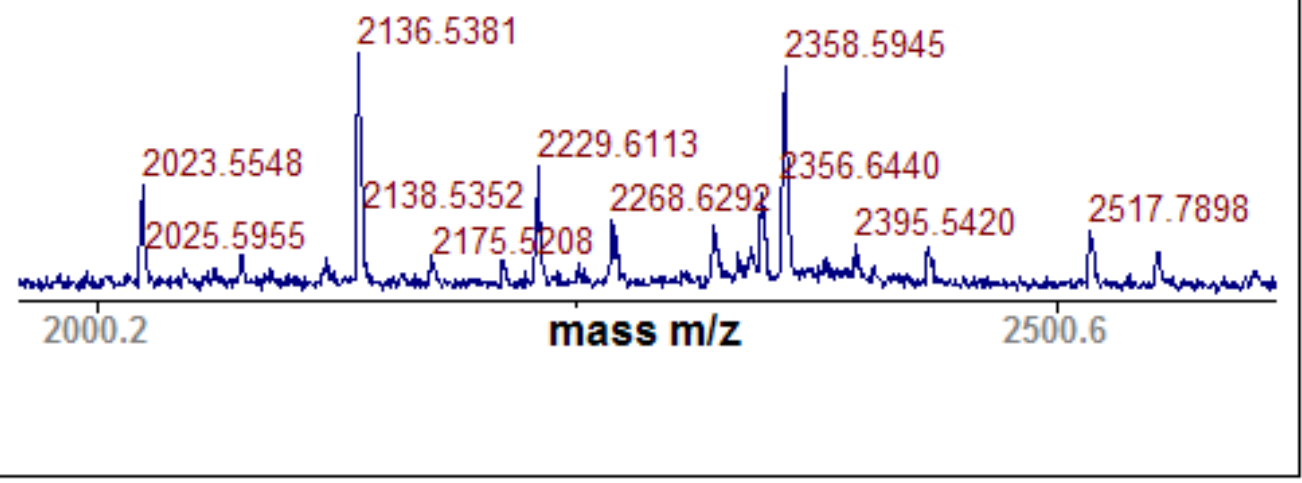

Fig. 17. MALDI-TOF spectrum of the GST-CBP(2300-2441) with (B) and without $(A)$ in vitro phosphorylation by GSK3 $\beta$ followed by combined trypsin/CNBr digestion

Bacterially expressed GST-CBP(2300-2441) (3 $\mu \mathrm{g})$ was subjected to in vitro phosphorylation by recombinant GSK3 3 . After staining of the SDS-PAGE gel with Coomassie, the band, containing GST-CBP(2300-2441), was excised, digested with trypsin then with $\mathrm{CNBr}$ and subjected to MALDI-TOF analysis.

(A) Spectrum of GST-CBP(2300-2441) without incubation with recombinant GSK3 $\beta$.

(B) Spectrum of GST-CBP(2300-2441) incubated with recombinant GSK3 $\beta$. 


\section{6 Sequence alignment of the C-terminal part of murine CBP and p300}

In contrast to CBP, p300 does not confer insulin and PKB responsiveness to the glucagon promoter (Schinner at al., 2005). Thus, the sequences, representing the C-terminal part of these proteins starting from amino acid 2300 of CBP were aligned (Fig. 18).

The GSK3 consensus phosphorylation site is Ser/Thr-X-X-X-Ser/Thr(P), where the first Ser/Thr is the target residue, $X$ is any amino acid and $\operatorname{Ser} / \operatorname{Thr}(P)$ is the site of priming phosphorylation (Harwood, 2001). Acidic amino acids like aspartate or glutamate might mimic the prephosphorylated residue due to the negative charge (Hunter, 1988).

A nine amino acid sequence SSELSLVGD (aa 2420 to 2428) within the C-terminal part of CBP was identified (Fig. 18, boxed). Serine-2420 and serine-2424 are not conserved between CBP and p300 and are, thus, potential targets for GSK3 $\beta$ phosphorylation, assuming that prephosphorylation is not required and aspartate might play the role of the"phosphorylated" amino acid. 


\section{Fig. 18. Sequence alignment of the C-terminal part of murine CBP and p300}

CBP sequences that meet the GSK3 $\beta$ consensus phosphorylation sequence, assuming a prephosphorylation event (S/T-X-X-X-S/T), are underlined in black; the GSK3 $\beta$ consensus phosphorylation sequence, assuming no prephosphorylation (S/T-X-X-X-D/E), is underlined in blue; potentially GSK3 $\beta$-targeted amino acids are underlined; potential targets for prephosphorylation are marked with $(\downarrow)$. A potential "hot-spot" for GSK3 $\beta$ phosphorylation is boxed. The serine residues, which were mutated in this study, are indicated with $\left(^{*}\right)$.

\section{7 Effect of mutations within the C-terminal part of CBP on the phosphorylation by GSK3 $\beta$ in vitro}

In order to test whether mutations within the C-terminal part of CBP (A2420A, S2424A S2420A plus S2424A) change its phosphorylation by GSK3 $\beta$, in vitro kinase assays were performed. As shown in Fig. 19, all three mutations significantly reduced the phosphorylation by recombinant GSK3 $\beta$. The negative control (GST) was not phosphorylated. Quantitative results obtained by densitometry are presented in Fig. 20. The relative phosphorylation by GSK3 $\beta$ is $19 \pm 5 \%$ for GST-CBP(2300-2441)S2420A, 15 $\pm 2 \%$ for GST-CBP(2300-2441)S2424A and $17 \pm 1 \%$ for GST-CBP(2300-2441) S2420A/S2424A respectively. The phosphorylation of GST-CBP(2300-2441) wild type was set to $100 \%$. 

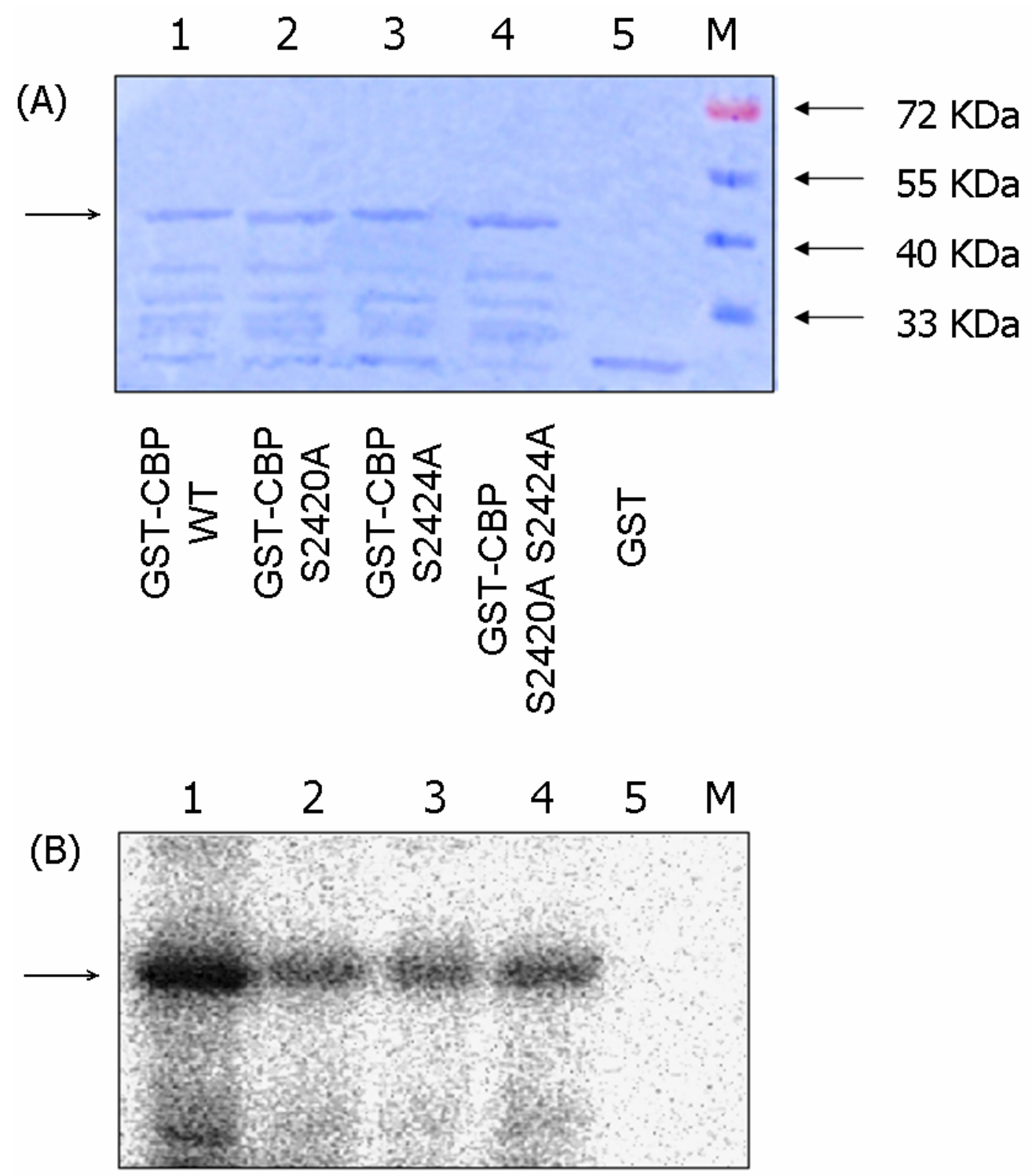

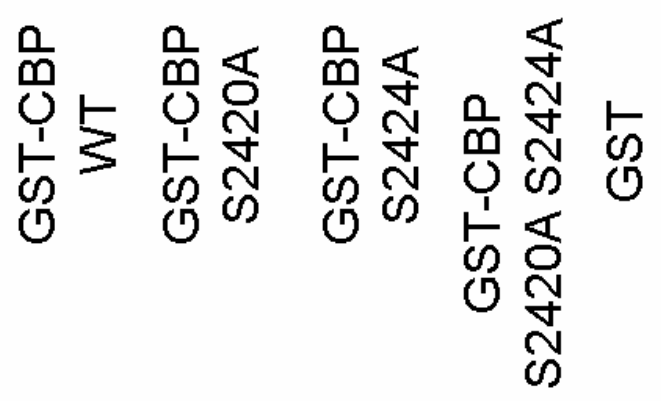

Fig. 19. Effect of mutations within the C-terminal part of CBP on its phosphorylation by GSK3 $\beta$ in vitro

(A) Coomassie-stained SDS-PAGE gel of the GST-CBP fusion proteins.

$3 \mathrm{\mu g}$ of bacterially expressed GST-CBP(2300-2441)WT (lane 1), GST-CBP(23002441)S2420A (lane 2), GST-CBP(2300-2441)S2424A (lane 3), GST-CBP(2300-2441) S2420A/S2424A (lane 4) and GST (lane 5) were subjected to in vitro kinase assay with recombinant GSK3 $\beta$ in the presence of radioactively labelled $y^{-}{ }^{32} P$-ATP. The reaction was stopped by adding $2 X$ SDS sample buffer and the samples were loaded on a SDS-PAGE gel, stained with coomassie and destained. 
(B) After drying, the gel was subjected to autoradiography. GST-CBP fusion proteins; GST-CBP(2300-2441)WT (lane 1), GST-CBP(2300-2441)S2420A (lane 2), GSTCBP(2300-2441)S2424A (lane 3), GST-CBP(2300-2441) S2420A/S2424A (lane 4) and GST (lane 5). Typical gel out of three independent experiments is shown. GST Glutathione S-Transferase, M - molecular weight marker.

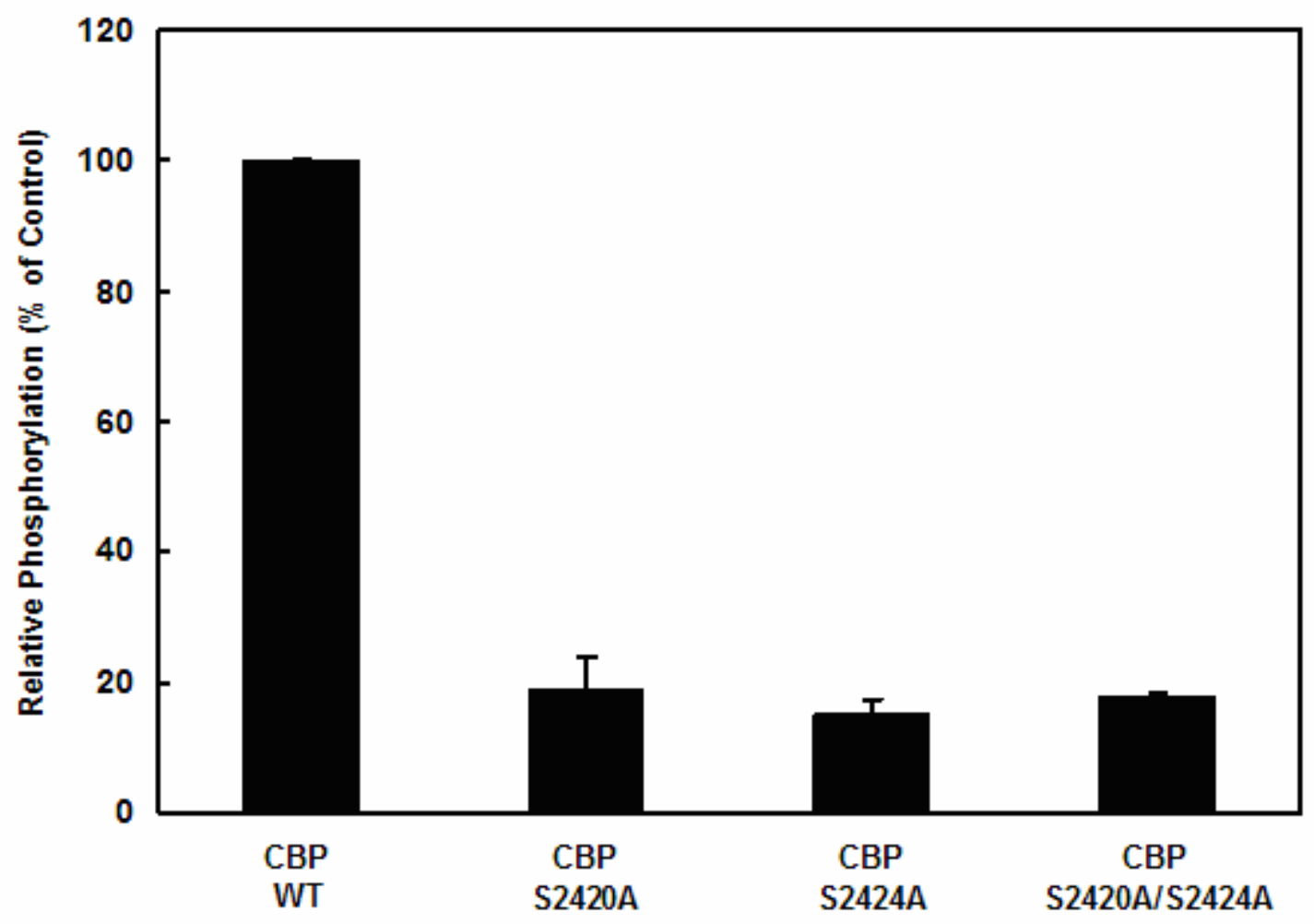

Fig. 20. Effect of mutations within CBP(2300-2441) on its phosphorylation by GSK3 $\beta$ in vitro: densitometry

$3 \mu \mathrm{g}$ of the GST-CBP fused proteins GST-CBP(2300-2441)WT, GST-CBP(2300-2441) S2420, GST-CBP(2300-2441)S2424A and GST-CBP(2300-2441)S2420A/S2424A were subjected to an in vitro kinase assay with recombinant GSK3 $\beta$ in the presence of adioactively labelled $\mathrm{y}^{-32} \mathrm{P}$-ATP. The samples were resolved on a SDS-PAGE gel, stained with Coomassie, destained and subjected to autoradiography. After autoradiography the data were analyzed by phosphoimager. In each experiment, the phosphorylation of GST$\mathrm{CBP}(2300-2441)$ wild type was set to $100 \%$. Values are means $\pm \mathrm{S}$. E. of three independent experiments.

\section{8 Effect of mutations within the C-terminal part of CBP on its basal transcriptional activity}

In order to examine the functional significance of the CBP mutants S2420A and S2424A, the GAL4 system was used. The wild type and the mutated CBP proteins were fused to the GAL4 DNA-binding domain (amino acids 1-147). The GAL4 DNA-binding domain was derived from the yeast transcriptional factor GAL4. The GAL4-CBP fusion constructs were transiently transfected into the InR1G9 cell line together with a luciferase reporter gene 
placed under the control of a minimal, viral E1B promoter and five copies of the GAL4DNA-binding site (construct $5 \times \mathrm{Kal} 4(\mathrm{E} 1 \mathrm{~B}) \mathrm{Luc}$ ) or of the mutated glucagon promoter, (construct 350(G1m/G3m)GluLuc).

When compared with -350 GluLuc, the basal transcriptional activity observed using 5xGal4(E1B)Luc of other CBP constructs was: $804 \pm 113 \%$ (GAL4-CBP(2040-2441)WT), $532 \pm 109 \%$ (GAL4-CBP(2040-2441)S2420A), $234 \pm 68 \%$ (GAL4-CBP(2040-2441) S2424A), $2 \pm 0 \%$ (GAL4-CBP(2040-2441)S2420A/S2424A) (Fig. 21).

When the same constructs were cotransfected with the mutated glucagon reporter gene, in which the Pax6 binding sites within the $\mathrm{G} 1$ and $\mathrm{G} 3$ elements had been mutated into GAL4 binding sites, the basal activity of the constructs was compared with -350GluLuc: $277 \pm 20 \%$ (GAL4-CBP(2040-2441)WT), $119 \pm 7 \%$ (GAL4-CBP(2040-2441)S2420), $59 \pm$ $6 \%$ (GAL4-CBP(2040-2441)S2424A), $4 \pm 0 \%$ (GAL4-CBP(2040-2441)S2420A/S2424A) (Fig. 22). No basal activity of the yeast transcriptional factor GAL4(1-147) was observed (Fig. 22).

The construct, in which serines 2420 and 2424 were both mutated to alanine, conferred no basal activity. This may indicate poor expression of this construct.

\section{9 Effect of insulin on the transcriptional activity mediated by the wild type CBP and mutated CBP constructs}

In order to investigate the insulin responsiveness of the GAL4-CBP fusion proteins, the following procedure was done. InR1G9 cells were transiently transfected with GAL4-CBP fusion constructs together with a luciferase reporter gene placed under the control of the minimal, adenoviral E1B promoter and five copies of a GAL4-binding site (5xGal4(E1B)Luc) or mutated glucagon promoter (-350(G1m/G3m)GluLuc). $23 \mathrm{~h}$ after transfection the medium was changed to medium without serum and $1 \mathrm{~h}$ later cells were treated with $100 \mathrm{nM}$ insulin.

When compared to the respective non-treated cells, the transcriptional activity under insulin treatment (using 5xGal4(E1B)Luc) was: $107 \pm 3 \%$ (GAL4), $97 \pm 7 \%$ (GAL4-CBP (2040-2441) WT), $76 \pm$ 10\% (GAL4-CBP(2040-2441)S2420A), $84 \pm 4 \%$ (GAL4-CBP (2040-2441)S2424A), $139 \pm$ 14\% (GAL4-CBP(2040-2441)S2420A/S2424A) (Fig. 23). 350 GluLuc was inhibited by insulin to $47 \pm 4 \%$ (Fig. 23).

When the same constructs were cotransfected with the mutated glucagon reporter gene, in which the Pax6 binding sites within the G1 and G3 elements had been mutated into GAL4 binding sites $(-350(\mathrm{G} 1 \mathrm{~m} / \mathrm{G} 3 \mathrm{~m}) \mathrm{GluLuc})$, the transcriptional activity under insulin treatment was: $89 \pm 2 \%$ (GAL4), $57 \pm 8 \%$ (GAL4-CBP(2040-2441) WT), $50 \pm 9 \%$ (GAL4- 
CBP(2040-2441)S2420A), $55 \pm 8 \%$ (GAL4-CBP(2040-2441)S2424A), $89 \pm 4 \%$ (GAL4CBP(2040-2441)S2420A/S2424A) (Fig. 24). -350GluLuc was inhibited by insulin to $38 \pm$ $7 \%$ (Fig. 24).

\section{10 Effect of mutations within the C-terminal fragment of CBP on GSK3 $\beta$ responsiveness}

To test the GSK3 $\beta$ responsiveness, the constructs were cotransfected into the InR1G9 cell line with either GSK3 $\beta$ wild type or a kinase-dead GSK3 $\beta$ mutant, together with a luciferase reporter gene placed under the control of a minimal, adenoviral E1B promoter and five copies of a GAL4-binding site (5xGal4(E1B)Luc) or mutated glucagon promoter (-350(G1m/G3m)GluLuc).

When cotransfected with 5xGAL4(E1B)Luc, GSK3 $\beta$ WT responsiveness of the constructs was: $149 \pm 19 \%$ (GAL4), $120 \pm 34 \%$ (GAL4-CBP(2040-2441)WT), $117 \pm 12 \%$ (GAL4-CBP (2040-2441)S2420A), $158 \pm 20 \%$ (GAL4-CBP(2040-2441)S2424A), $92 \pm 9 \%$ (GAL4-CBP (2040-2441)S2420A/S2424A) (Fig. 25). GSK3 $\beta$ WT responsiveness of -350Gluluc was $277 \pm 73 \%$ (Fig. 25).

When the same constructs were cotransfected with the mutated glucagon reporter gene, in which the Pax6 binding sites within the $\mathrm{G} 1$ and $\mathrm{G} 3$ elements had been mutated into GAL4 binding sites (-350(G1m/G3m)GluLuc), GSK3 $\beta$ WT responsiveness of the constructs was $157 \pm 6 \%$ (GAL4), $255 \pm 25 \%$ (GAL4-CBP(2040-2441)WT), $376 \pm 74 \%$ (GAL4-CBP(2040-2441)S2420A), $160 \pm 13 \%$ (GAL4-CBP(2040-2441)S2424A), $161 \pm$ 26\% (GAL4-CBP(2040-2441)S2420A/S2424A) (Fig. 26). GSK3 $\beta$ WT responsiveness of 350 Gluluc was $234 \pm 36 \%$ (Fig. 26).

Thus, the mutation of serine-2424 to alanine significantly reduced the GSK3 $\beta$-induced activation of glucagon gene transcription by more than $50 \%$ (Fig 27 ). 


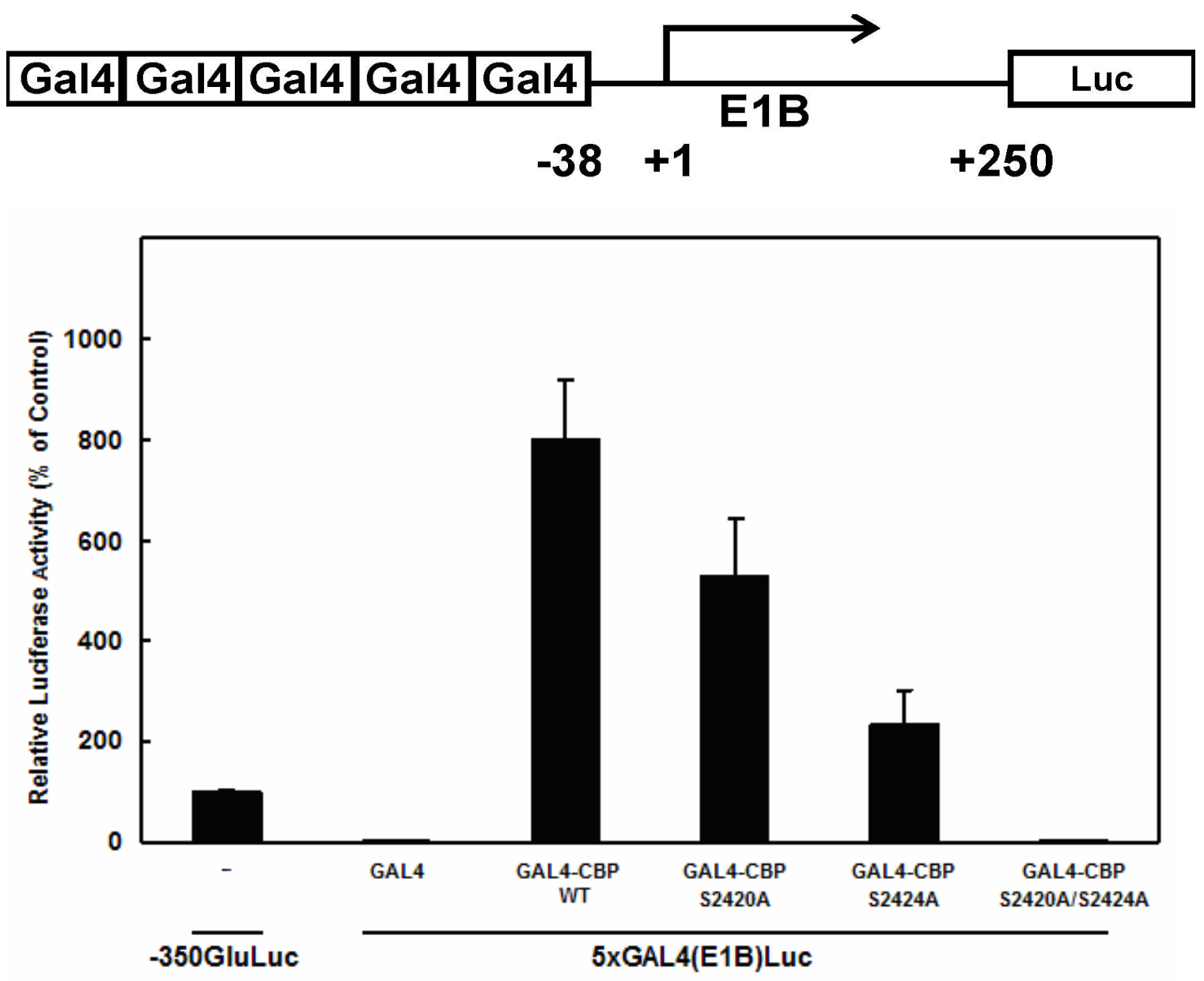

Fig. 21. Effect of mutations within the C-terminal part of CBP on its basal transcriptional activity, using 5xGAL4(E1B)Luc

Expression vectors encoding GAL4 and GAL4-CBP fusion proteins ( $2 \mu \mathrm{g} / 6-\mathrm{cm}$ dish) were transfected into InR1G9 cells together with 5xGAL4(E1B)Luc reporter gene and pCMVGFP-tpz reporter plasmid. -350GluLuc was used as a positive control. Luciferase activity is expressed as percentage of the mean value, in each experiment, of the activity of $350 \mathrm{GluLuc}$. Values are means $\pm S$. E. of three independent experiments, each done in duplicate.

The upper panel represents a scheme of the 5xGAL4(E1B)Luc reporter gene used. 

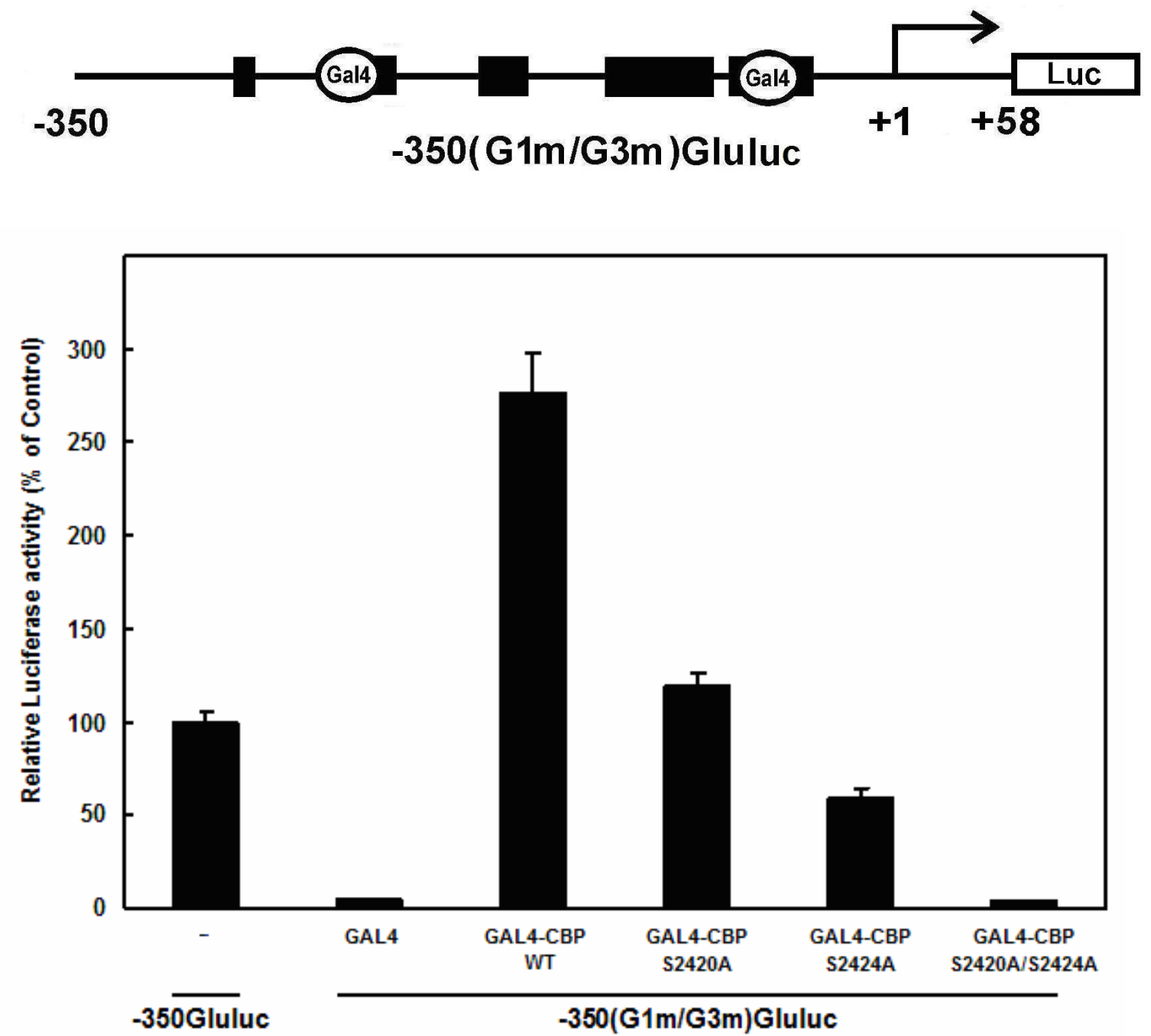

Fig. 22. Effect of mutations within the C-terminal part of CBP on its basal transcriptional activity, using $-350(\mathrm{G} 1 \mathrm{~m} / \mathrm{G} 3 \mathrm{~m})$ GluLuc

Expression vectors encoding GAL4 and GAL4-CBP fusion proteins ( $2 \mu \mathrm{g} / 6-\mathrm{cm}$ dish) were transfected into InR1G9 cells together with $-350(\mathrm{G} 1 \mathrm{~m} / \mathrm{G} 3 \mathrm{~m}) \mathrm{GluLuc}$ reporter gene and pCMV-GFP-tpz reporter plasmid. -350GluLuc was used as a positive control. Luciferase activity is expressed as percentage of the mean value, in each experiment, of the activity of -350 GluLuc. Values are means $\pm S$. E. of three independent experiments, each done in duplicate.

The upper panel represents a scheme of the mutated glucagon reporter gene used. 

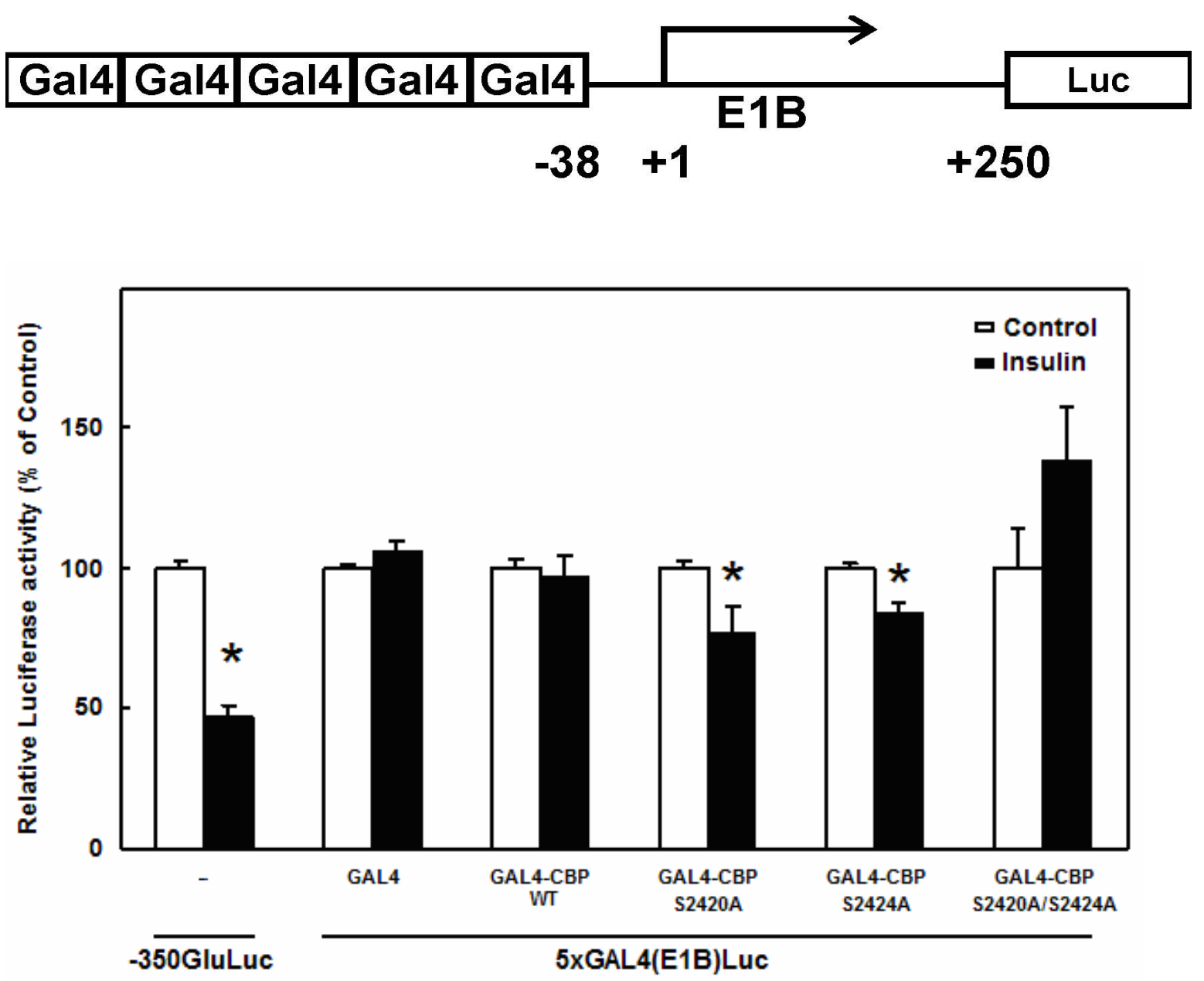

Fig. 23. Effect of insulin on the transcriptional activity mediated by wild-type GAL4CBP(2040-2441) and its mutants, using 5xGAL4(E1B)Luc

Expression vectors encoding GAL4 and GAL4-CBP fusion proteins ( $2 \mu \mathrm{g} / 6-\mathrm{cm}$ dish) were transfected into InR1G9 cells together with the 5xGAL4(E1B)Luc reporter gene and pCMV-GFP-tpz reporter plasmid. -350GluLuc was used as a positive control. After transfection, InR1G9 cells were treated with insulin (100 nM) for $23 \mathrm{~h}$ before harvesting, or left untreated (control). Luciferase activity is expressed relative to the mean value in each experiment of the activity measured in the respective control (no insulin treatment). Values are means $\pm S$. E. of three independent experiments, each done in duplicate. ${ }^{*} P<0.05$ (Student's $t$-test).

The upper panel represents a scheme of the 5xGAL4(E1B)Luc reporter gene used. 

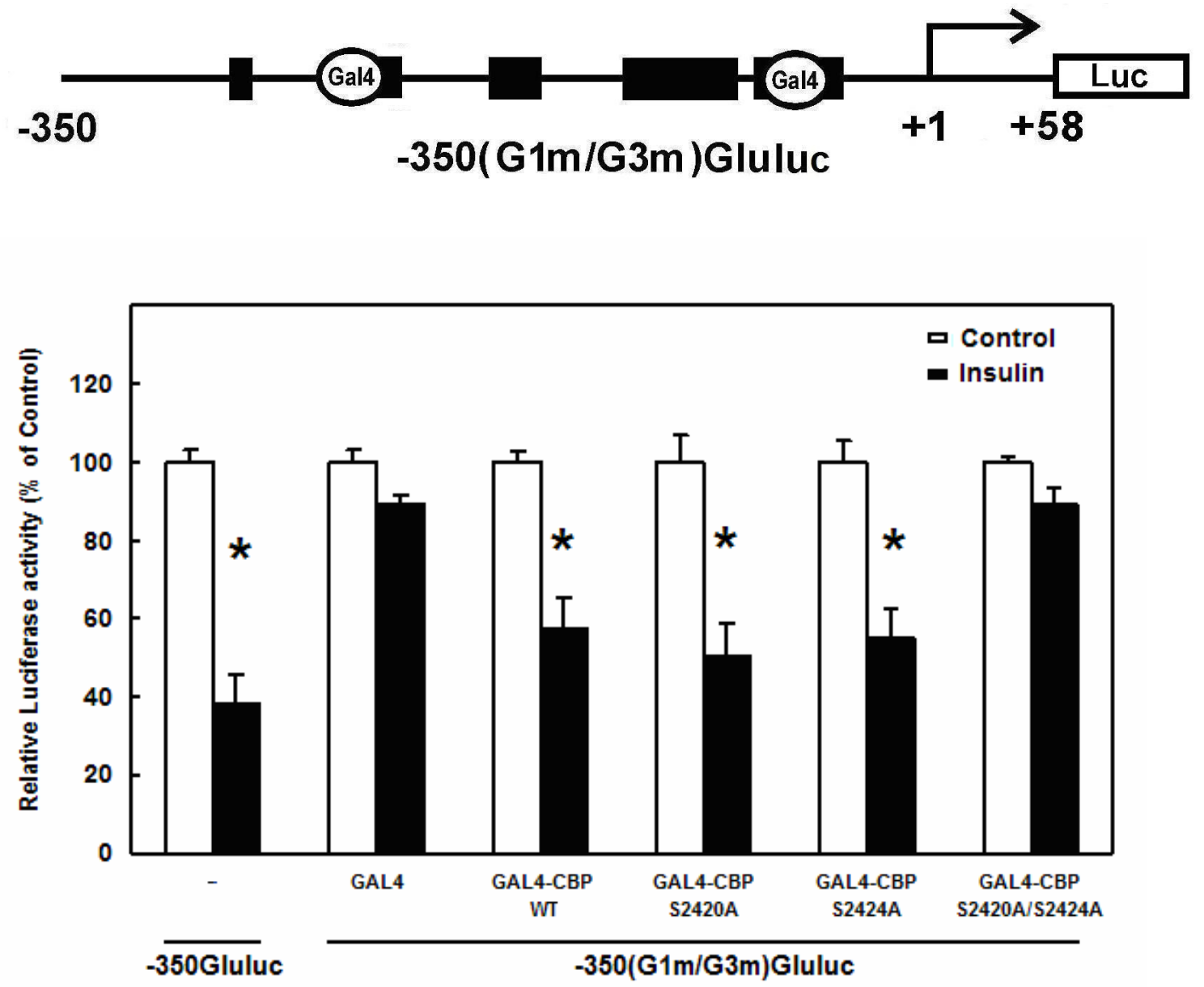

Fig. 24. Effect of insulin on the transcriptional activity mediated by wild-type GAL4CBP(2040-2441) and its mutants, using -350(G1m/G3m)GluLuc

Expression vectors encoding GAL4 and GAL4-CBP fusion proteins ( $2 \mu \mathrm{g} / 6-\mathrm{cm}$ dish) were transfected into InR1G9 cells together with the $-350(\mathrm{G} 1 \mathrm{~m} / \mathrm{G} 3 \mathrm{~m})$ GluLuc reporter gene and pCMV-GFP-tpz reporter plasmid. -350GluLuc was used as a positive control. After transfection, InR1G9 cells were treated with insulin (100 nM) for $23 \mathrm{~h}$ before harvesting, or left untreated (control). Luciferase activity is expressed relative to the mean value in each experiment of the activity measured in the respective control (no insulin treatment). Values are means $\pm S$. E. of three independent experiments, each done in duplicate. ${ }^{*} P<0.05$ (Student's $t$-test).

The upper panel represents a scheme of the mutated glucagon reporter gene used. 

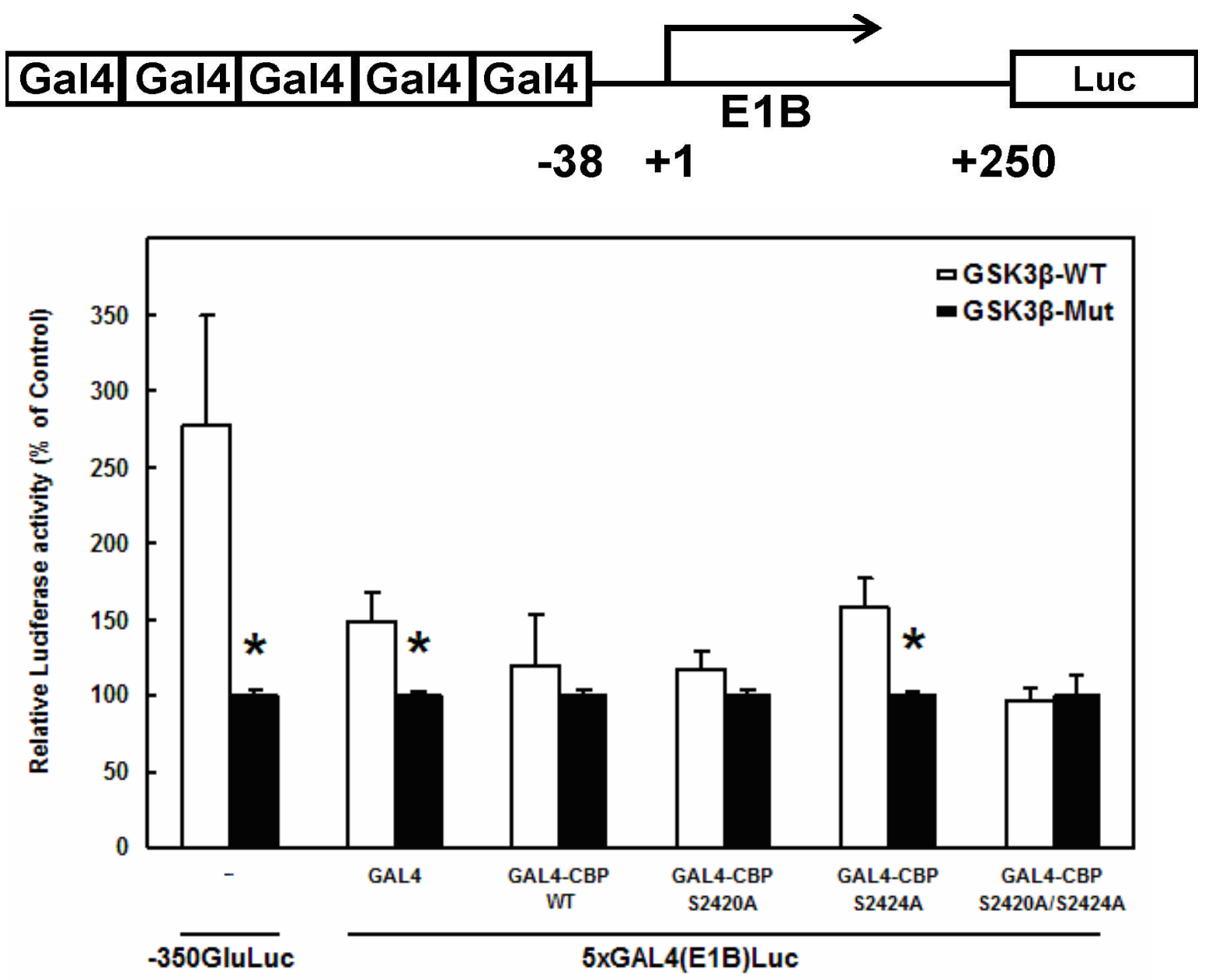

Fig. 25. Effect of mutations within the C-terminal fragment of CBP on GSK3 $\beta$ responsiveness, using 5xGAL4(E1B)Luc

Expression vectors encoding GAL4 and GAL4-CBP fusion proteins ( $2 \mu \mathrm{g} / 6-\mathrm{cm}$ dish) were transfected into InR1G9 cells together with GSK3 $\beta$ WT or the kinase-dead GSK3 $\beta$ Mut (2 $\mu \mathrm{g}$ per $6-\mathrm{cm}$ dish, respectively) together with the $5 \times \mathrm{XAL} 4(\mathrm{E} 1 \mathrm{~B}) \mathrm{Luc}$ reporter gene and pCMV-GFP-tpz reporter plasmid. -350GluLuc was used as a positive control. Luciferase activity is expressed relative to the mean value in each experiment of the activity measured in the respective control (cells with GSK3 $\beta$ Mut cotransfected). Values are means $\pm S$. E. of three independent experiments, each done in duplicate. ${ }^{*} P<0.05$ (Student's $t$-test).

The upper panel represents a scheme of the 5xGAL4(E1B)Luc reporter gene used. 

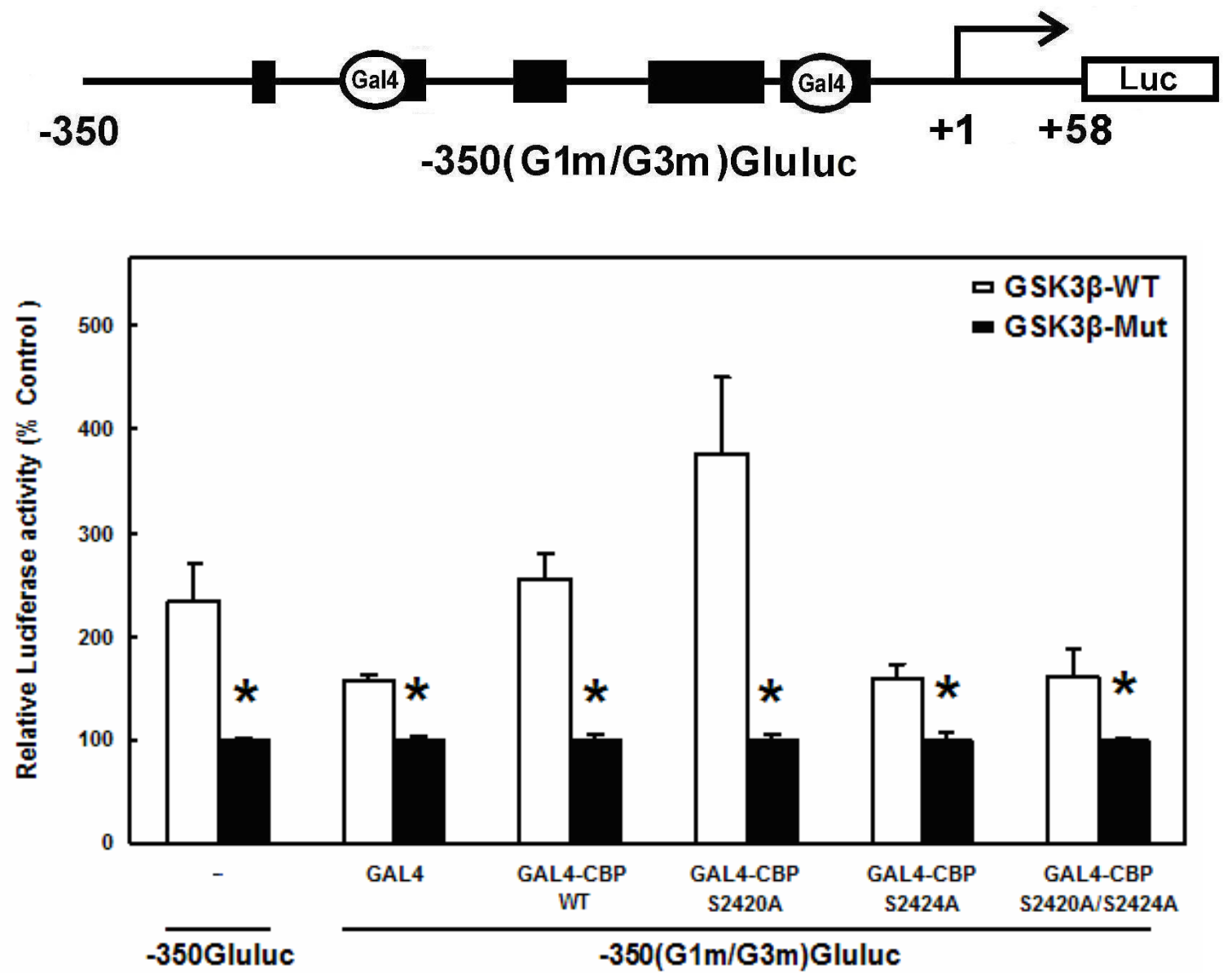

Fig. 26. Effect of mutations within the C-terminal fragment of CBP on GSK3 $\beta$ responsiveness, using $-350(\mathrm{G} 1 \mathrm{~m} / \mathrm{G} 3 \mathrm{~m})$ GluLuc

Expression vectors encoding GAL4 and GAL4-CBP fusion proteins ( $2 \mu \mathrm{g} / 6-\mathrm{cm}$ dish) were transfected into InR1G9 cells with GSK3 $\beta$ WT or the kinase-dead GSK3 $\beta$ Mut (2 $\mu$ g per 6 $\mathrm{cm}$ dish, respectively) together with $-350(\mathrm{G} 1 \mathrm{~m} / \mathrm{G} 3 \mathrm{~m})$ GluLuc reporter gene and pCMVGFP-tpz reporter plasmid. -350GluLuc was used as a positive control. Luciferase activity is expressed relative to the mean value in each experiment of the activity measured in the respective control (cells with GSK3 $\beta$ Mut cotransfected). Values are means $\pm S$. E. of three independent experiments, each done in duplicate. ${ }^{*} P<0.05$ (Student's $t$-test).

The upper panel represents a scheme of the mutated glucagon reporter gene used. 


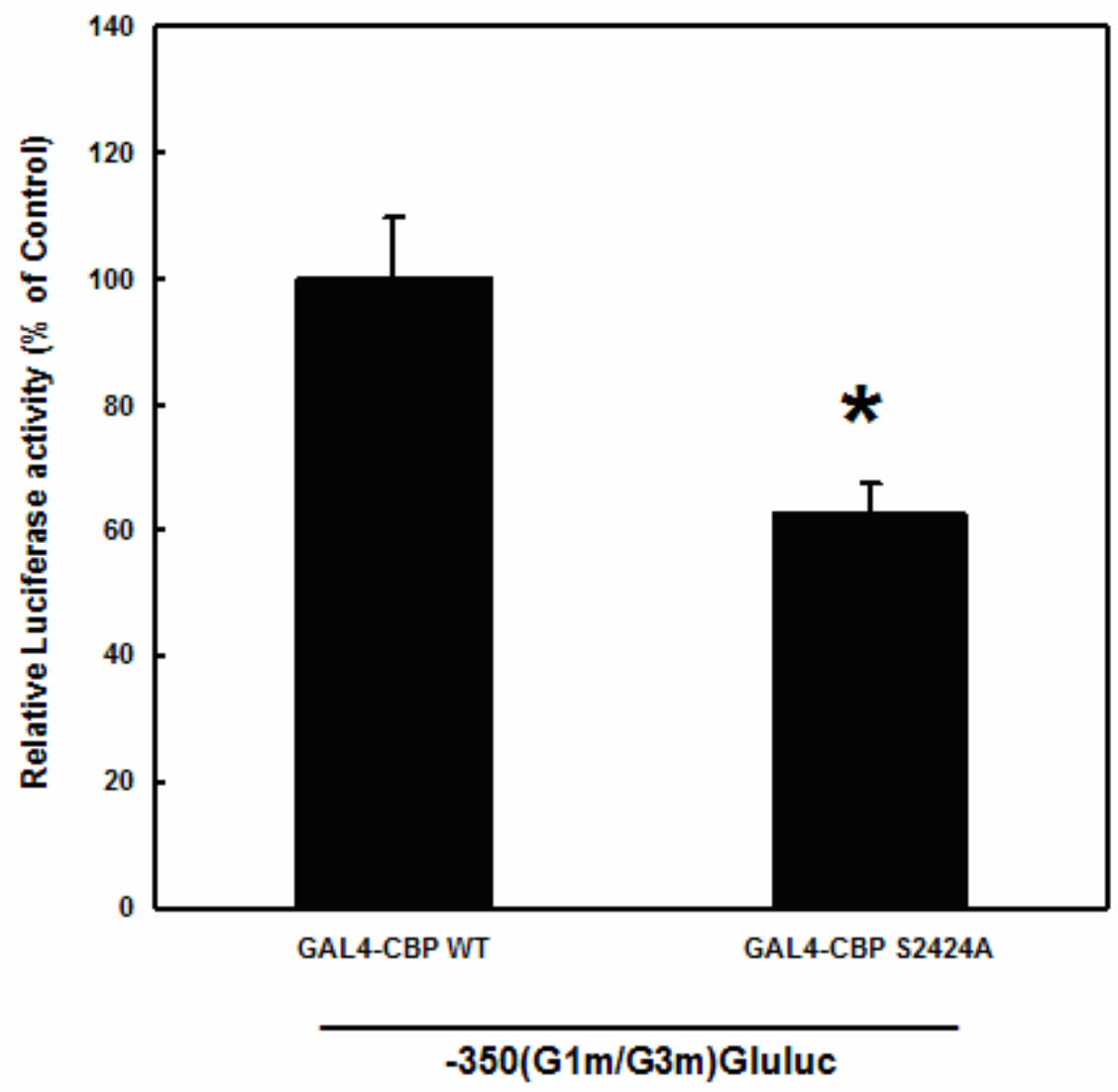

Fig. 27. Effect of the mutation of serine 2424 to alanine within the C-terminal part of CBP on the GSK3 $\beta$ WT-induced increase in glucagon gene transcription

The plasmids GAL4-CBP(2040-2441)WT, GAL4-CBP(2040-2441)S2424A were transfected into InR1G9 cells $(2 \mu \mathrm{g}$ per $6-\mathrm{cm}$ dish respectively) with GSK3 $\beta$ WT $(2 \mu \mathrm{g}$ per $6-\mathrm{cm}$ dish) together with $-350(\mathrm{G} 1 \mathrm{~m} / \mathrm{G} 3 \mathrm{~m})$ GluLuc reporter gene and pCMV-GFP-tpz reporter plasmid. Luciferase activity is expressed as percentage of the mean value, in each experiment, of the activity measured in the control (sample with GAL4-CBP(20402441)WT) (Calculated from data in Fig. 26). Values are means \pm S. E. of three independent experiments, each done in duplicate. ${ }^{*} P<0.005$ (Student's $t$-test).

\section{11 Expression levels of GAL4-CBP(2040-2441)WT and Gal4-CBP(2040-2441)} S2424A in InR1G9 cells

In order to test whether GAL4-CBP(2040-2441) WT and Gal4-CBP(2040-2441)S2424A are equally expressed, the ellectrophoretic mobility shift assay was performed. InR1G9 cells were transiently transfected with either GAL4-CBP(2040-2441)WT, Gal4-CBP(20402441)S2424A, pBluescript (negative control) or GAL4-CREB (positive control) in the presence of GSK3 $\beta$ WT. An extract of nuclear proteins was prepared $48 \mathrm{~h}$ after transfection and an EMSA was performed (Fig 28 A). pBluescript (lanes 1, 2), GAL4-CBP (2040-2441)WT (lanes 3, 4) and Gal4-CBP(2040-2441)S2424A (lanes 5, 6) were 
transfected in duplicate, GAL4-CREB (lane 7), non-transfected cells (lane 8), free GAL4 probe (lane 9). Next, the gel was dried, subjected to autoradiography and analyzed by phosphoimager. The relative expression of Gal4-CBP(2040-2441)S2424A was $87 \pm 6 \%$ compared to wild type (100 $\pm 0 \%$ ) (Fig. 28 B).

(A)

+ GSK3 $\beta$

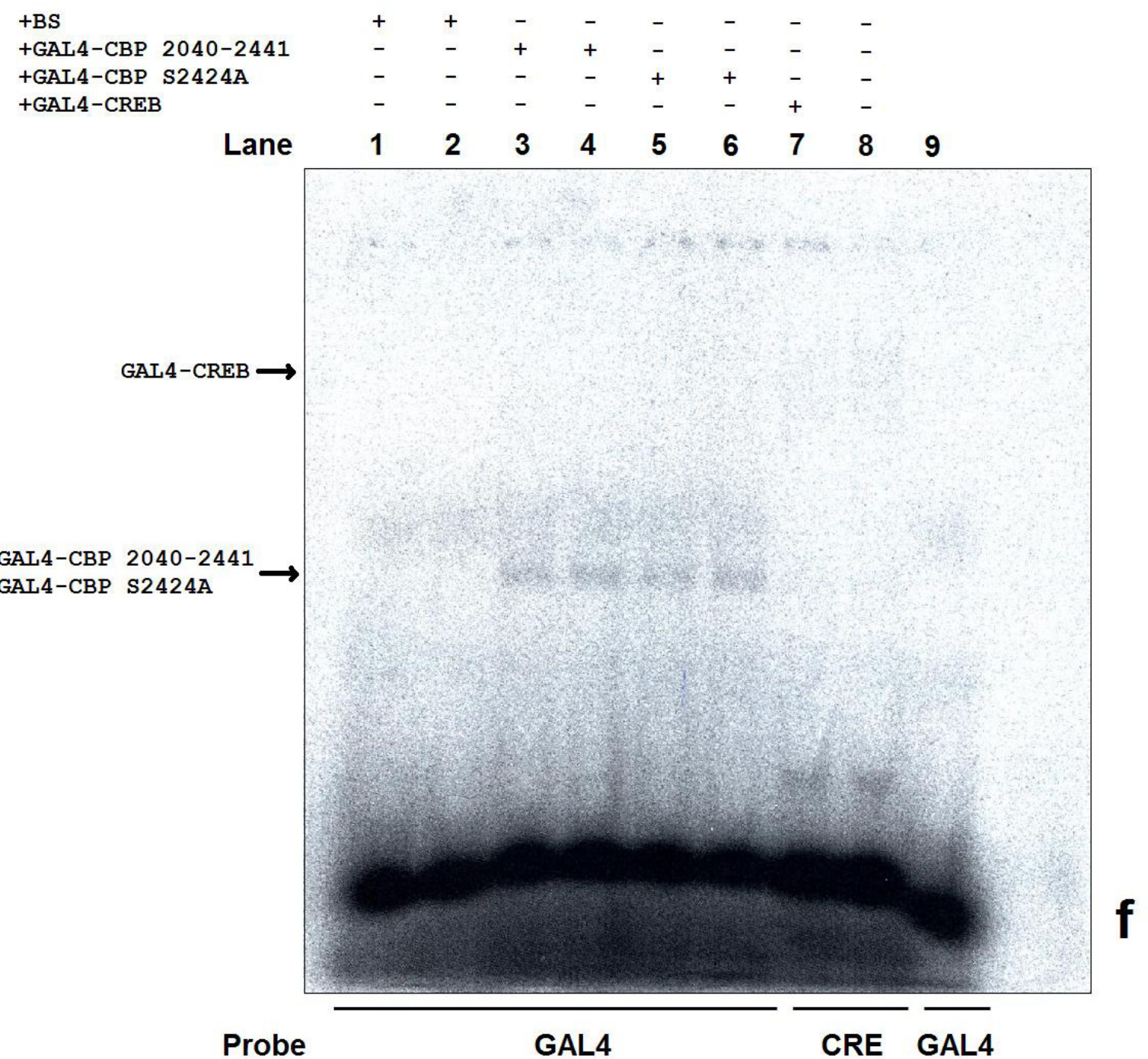


(B)

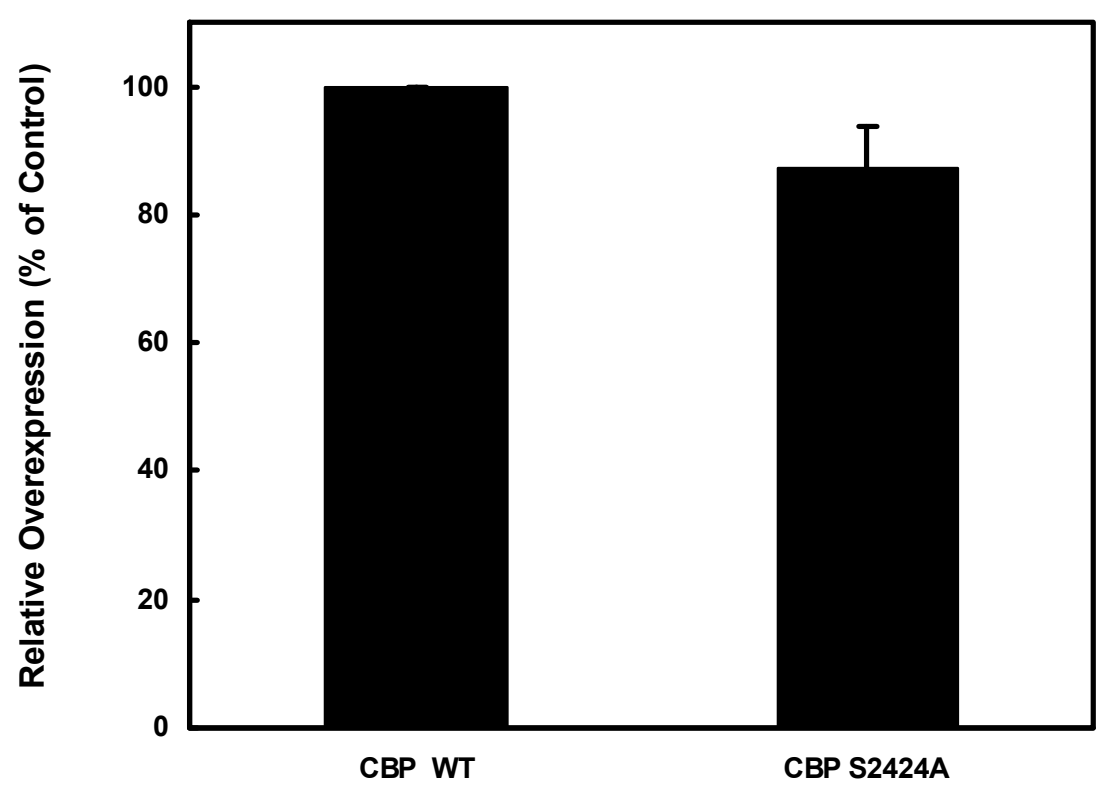

Fig. 28. Relative expression of GAL4-CBP(2040-2441)WT and Gal4-CBP(20402441)S2424A in InR1G9 cells

(A) Radioactively labelled GAL4 or CRE oligonucleotides were incubated with equal amounts of nuclear extracts prepared from InR1G9 cells transiently transfected with Bluescript (lanes 1-2), GAL4-CBP(2040-2441) (lanes 3-4), GAL4-CBP(2040-2441) S2424A (lanes 5-6), GAL4-CREB (lane 7) or non-transfected (lane 8). GAL4-CBP(20402441), GAL4-CBP(2040-2441)S2424A and GAL4-CREB- specific bands are indicated.. $\mathrm{BS}$, Bluescript, f, free probe.

(B) After drying, the gel was subject to autoradiography and analyzed by phosphoimager. Values are means $\pm \mathrm{S}$. E. of two independent experiments, each done in duplicate. 


\section{Discussion}

The peptide hormone insulin elicits a broad array of metabolic responses. In muscle and adipose tissue, insulin promotes the storage of glucose by coordinately accelerating both the rate of glucose entry into the cell and glycogen synthase activity (Summers et al., 1999). Upon binding to its receptor, insulin induces a signal cascade leading to inhibition of glucagon synthesis and glucagon gene transcription. Abnormal regulation of these processes results in hyperglucagonemia and hyperglycaemia contributing to impaired glucose tolerance in diabetes mellitus type 2 (Kahn et al., 2003).

The detailed understanding of the mechanism resulting in inhibition of glucagon gene transcription by insulin is critical for the development of novel therapeutic strategies to treat diabetes mellitus.

In order to study insulin-caused inhibition of glucagon gene transcription, we used an insulin-responsive tumor alpha cell line InR1G9 (Takaki et al., 1986).

Recent studies from our laboratory suggest that insulin-mediated inhibition of glucagon gene transcription is conferred through the $\mathrm{PI}(3) \mathrm{K} / \mathrm{PKB}$ pathway (Schinner et al., 2005). It was suggested that the effect of insulin depends on the presence of both proximal promoter elements and more distal enhancer-like elements, with Pax6 playing a critical role in this interaction together with its potential coactivator CBP (Grzeskowiak et al., 2000). Some preliminary data indicated that GSK3 $\beta$ phosphorylates CBP(2040-2305) (Dimopoulos N., PhD Thesis, 2003).

In the present study GSK3 $\beta$ phosphorylation sites within the C-terminus of CBP were further characterized and their functional significance in the regulation of glucagon gene transcription by GSK3 $\beta$ and insulin was investigated. Our results suggest that CBP might represent the link downstream of GSK3 $\beta$ in response to insulin.

\section{1 GSK3 $\beta$ substrate specificity}

GSK3 was ascribed its name based on the function known at the time of discovery, that is to regulate glycogen synthase, but it is known to regulate a diverse array of cell functions. GSK3 has been implicated in fundamental processes including apoptosis, oncogenesis, neurological disorders and transcriptional control (reviewed by Frame and Cohen, 2001, Grimes and Jope, 2001). Since there was evidence that insulin-mediated inhibition of glucagon gene transcription is conferred through the $\mathrm{PI}(3) \mathrm{K} / \mathrm{PKB}$ pathway (Schinner et al., 
2005), and GSK3 is downstream of PKB in some other insulin signalling pathways (Woodgett, 2005), a role for GSK3 was investigated. A previous study provided evidence that GSK3 $\beta$ is involved in the regulation of glucagon gene transcription and in its inhibition by insulin (Dimopoulos N., PhD Thesis, 2003).

The consensus phosphorylation sequence for GSK3 substrates is Ser/Thr-X-X-XSer/ Thr- $P$, where the first Ser or Thr is the target residue, $X$ is any amino acid (but often Pro), and the last Ser-P/Thr-P is the site of priming phosphorylation. Although not strictly required, priming phosphorylation greatly increases the efficiency of substrate phosphorylation of most GSK-3 substrates by $100-1000$-fold (Thomas et al., 1999). For example, glycogen synthase, the prototypical primed substrate, requires priming phosphorylation by casein kinase II (CK2) and then undergoes sequential multisite phosphorylation by GSK3 (Fiol et al., 1988; Fiol et al., 1990) (Fig. 29B).
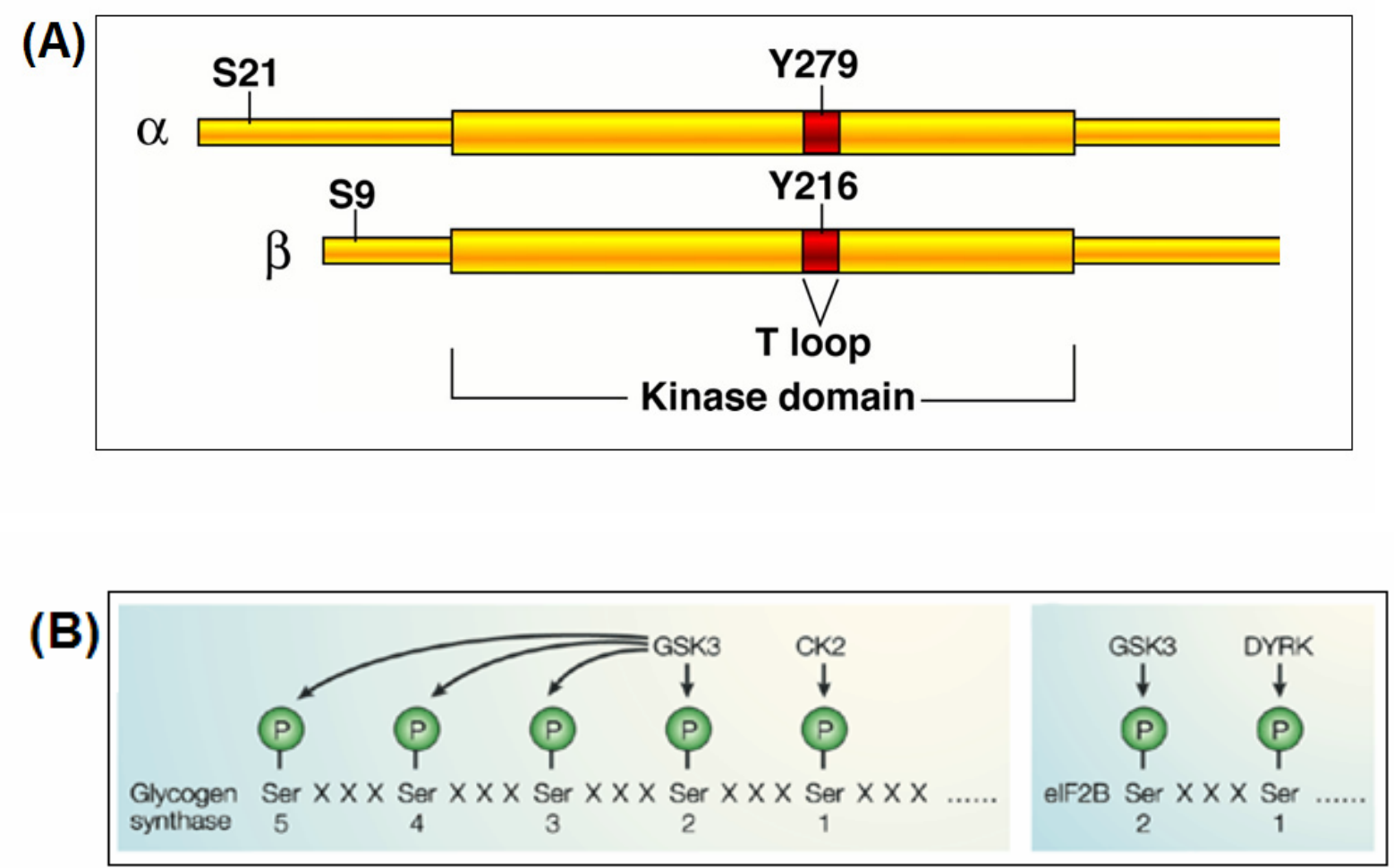

Nature Reviews | Molecular Cell Biology

Fig. 29. Schematic representation of two isoforms of GSK3 (A) and example of a typical GSK3 phosphorylation event (B)

A. Ser21 and Ser9 - PKB targets for GSK3 $\alpha$ and GSK3 $\beta$ respectively; kinase activation loops (T-loops) are highlighted in red.

B. GSK3 consensus site for the phosphorylation: GSK3 phosphorylates glycogen synthase after prephosphorylation by casein kinase 2 (CK2) (left panel) or phosphorylates elF2B after prephosphorylation by the Dual Specificity Tyrosine Phosphorylation Regulated Kinase (DYRK) (right panel). X - any amino acid (Cohen and Frame, 2001). 
The function expected for the 'missing' phosphothreonine in the GSK3's T-loop is believed to be replaced by the phosphorylated residue of a primed substrate, which binds to a positively charged pocket comprising R96, R180 and K205 (residue numbers for GSK-3ß). This not only optimizes the orientation of the kinase domains but also places the substrate at the correct position within the catalytic groove for the phosphorylation to occur (Doble and Woodgett, 2003). There are some substrates that lack a priming site (Ikeda et al., 1998; Diehl et al., 1998; Hanger et al., 1992, Trivedi et al., 2005; Twomy and McCarthy 2006). These proteins often display negatively charged residues at or near the priming position that may mimic a phospho-residue. Different examples of the substrates, which are phosphorylated by GSK3 are shown in Table 7.

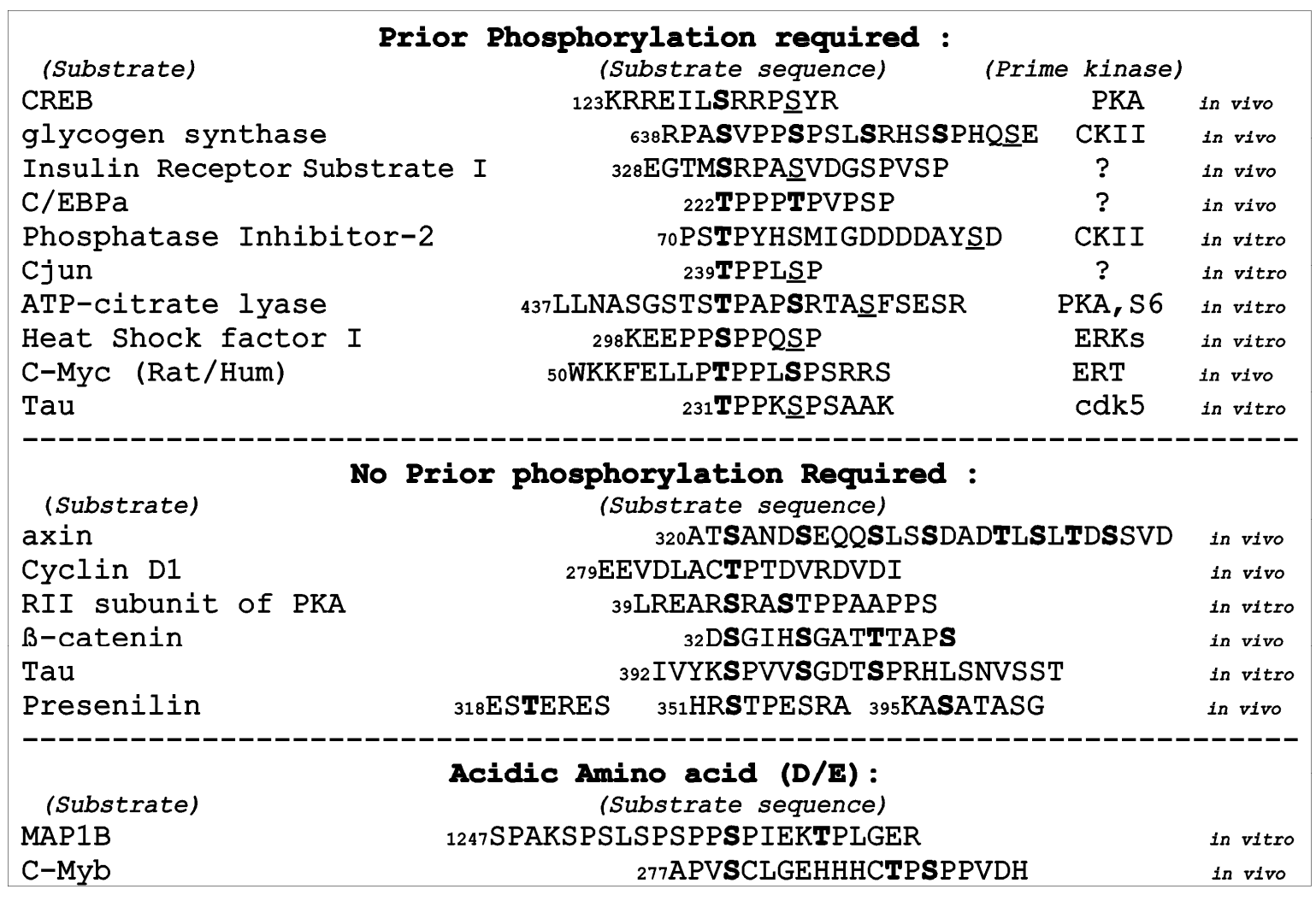

\section{Table. 7. Typical protein substrates of GSK3}

Upper panel. GSK3 substrates, which require priming phosphorylation.

Middle panel. GSK3 substrates, which are phosphorylated without prior phosphorylation Lower panel. GSK3 substrates, containing acidic amino acid, which mimics prephosporylated amino acid.

(Ali et al., 2001; Trivedi et al., 2005)

The microtubule-associated protein Tau was shown to be phosphorylated by GSK3 either without priming phosphorylation or after prephosphorylation by cdk5 kinase ( $\mathrm{Li}$ and Paudel, 2006). Despite of the fact, that regulation of Tau by GSK3 is not completely understood and taking into account that different GSK3 pools exist within the cell (Weston 
and Davis, 2001), it might provide evidence, that a certain substrate might regulate different cellular processes by the primed and non-primed phosphorylation.

\section{2 GSK3 $\beta$-induced phosphorylation of CBP}

It has been reported recently (Mikkola et al., 1999) that the transactivation domain (TAD) of zebrafish Pax6 is phosphorylated in vitro at three sites by the mitogen-acivated protein kinases (MAPKs): extracellular-signal regulated kinase (ERK) and p38 kinase. One of three in vitro phosphorylation sites is strongly evolutionary conserved and is also phosphorylated in vivo which stimulates the transactivation properties of the Pax6-TAD. However, the mutation of all three of these sites did not affect the ability of insulin to inhibit Pax6 transcriptional activity in InR1G9 cells (Grzeskowiak, 2000a). These findings therefore do not support a role for these mitogen-activated protein kinase phosphorylation sites in insulin action on the glucagon gene. Taking into account that CBP is able to interact with Pax6 (Hussain and Habener, 1999), as mentioned above, and the fact, that GSK3 is related phylogenetically to the family of mitogen-activated protein kinases (e.g. p38 kinase) as revealed from its crystal structure (Dajani et al., 2001), these results do not exclude the possibility that Pax6 might be actually a target for GSK3 $\beta$ in vivo. However, when taken together, the results of the present study provide evidence that CBP may directly be targeted by GSK3 $\beta$, which is the last downstream component in the insulininduced PI3K/PKB pathway in InR1G9 cells.

The regulation of CBP/p300 by phosphorylation is not deeply understood. CBP has been shown to be phosphorylated in response to stimuli such as calcium and insulin (Impey et al., 2002; Chawla et al., 1998; Hu et al., 1999; Nakajima et al., 1996). CBP has recently been shown to regulate hepatic gluconeogenesis by insulin-induced phosphrylation of serine-436 (Zhou et al., 2004). This mechanism is likely to be critically important for allowing the integration of information from different signal transduction pathways (Goodman and Smolik, 2000). Based on the previous finding that GSK3 $\beta$ is able to phosphorylate the transcriptional coactivator CBP aa 2040 to 2305 without priming phosphorylation in vitro (Dimopoulos N., PhD thesis, 2003), three CBP fragments from the C-terminal part of CBP from amino acids 2040 to 2441 were fused to GST and used in an in vitro kinase assay with recombinant GSK3ß. GST-CBP(2300-2441) was most heavily phosphorylated.

This finding is in agreement with the fact that many transcription activators undergo phosphorylation within the C-terminus, which might be easily accessible, thus regulating nuclear import and export and enhancing transactivation (Schwabe and Sakurai, 2005). 
Attempts were undertaken to show that GSK3 $\beta$ phosphorylates CBP also in vivo. Guided by literature data (Yan et al., 1998), we chose, as a first approach, immunoprecipitation followed by immunoblotting with phosphospecific antibodies, because it is a sensitive method, which is highly suitable for the detection of specific residues in individual phosphoproteins. The potential specificity of such antibodies, generated against specific phosphorylated epitopes, makes site-specific recognition feasible, providing the relevant antibodies can be prepared. CBP fragments were extended C-terminally with HA-tag and immunoprecipitated with anti-HA antibody after transient transfection into InR1G9 cells.

In order to detect phosphorylation, various antibodies able to recognize phosphorylated serine and/or phosphorylated threonine were chosen. In a series of experiments, these antibodies were shown to be unable to detect CBP phosphoproteins under the conditions used.

As positive controls phosphoserine conjugated to BSA and phosphothreonine conjugated to $B S A$ as well as phosphorylated CREB were used. While the antiphosphoserine antibody failed to recognize phosphorylated CREB, CREB phosphorylation was easily detectable with a well known antiphosphoCREB(S133P) antibody (Serine-133 is phosphorylated). Since the antibody, which was used first appeared to be unable to detect even the positive control GST-CREB, containing phosphorylated Ser-133, we decided to try a polyclonal antibody against phosphorylated serine derived from rabbit which has been used by others successfully (Blume-Jenssen and Hunter, 2001; Downward, 2001). However, this antibody was as well unable to detect phosphorylated CBP and CREB. These negative results might be explained by the assumption that the antibody may recognize the phosphorylated amino acid only in a specific phosphoprotein or peptide context. Certain proteins, known to contain phosphorylated amino acid were not recognized by these antibodies due to steric hindrance of the recognition site (Yan et al., 1998). Thus, antibodies raised specifically against CBP peptide sequences including phosphoserine-2420 and phosphoserine 2424 may be more helpful.

As a second method that may allow to study the phosphorylation of CBP in vivo, MALDITOF mass-spectrometry was examined. Thus, in vitro phosphorylation with recombinant GSK3 $\beta$ and GST-fused CBP proteins were performed and followed by MALDI-TOF mass spectrometry. In some cases, the precise measurement of the molecular weight of the intact protein, using mass spectrometry, can give an idea of the average number of modified residues present in the protein, just by looking at the increment of the protein mass in comparison with the unmodified one (Areces et al., 2004). To better characterize the phosphorylated residues of the protein, however, it is necessary to analyze peptides generated by enzymatic or chemical degradation of the protein. Ideally, all potential phosphopeptides should be detected. In practice, however, it is difficult to obtain a $100 \%$ 
sequence coverage of the protein (Areces et al., 2004). After several series of experiments with various conditions, we were unable to detect a difference in the molecular weight of the peptides obtained from the samples incubated without and with GSK3 $\beta$. It is important to understand that despite of a phosphorylation event it might be impossible to detect it. This could be due to a limitation in a dynamic range of MALDI-TOF when the peptide might not be seen if it is present in a very low abundance relative to another peptide in the same fraction. Other reasons might be ionization efficiency (phosphogroup might be eliminated during ionization as well) which is sequence specific or difficulties during protein digestion - certain protein sequences might lack an amino acid composition required for recognition by cleavage reagents like $\mathrm{CNBr}$ or trypsin. In the last case, peptides obtained will be out of the $\mathrm{m} / \mathrm{z}$ range which is less then 3000 in most cases if phosphorylation detection by MALDI-TOF is performed. This was the reason why we did not perform an analysis of the C-terminal part of CBP from amino acid 2160 to 2305; trypsin cleavage will result in the generation of fragments with about 4000 and higher $\mathrm{m} / \mathrm{z}$ ratios.

\section{3 Phosphorylation of CBP sequences that meet the GSK3 $\beta$ consensus phosphorylation site and are not conserved in p300}

Based on the fact that GSK3 $\beta$ phosphorylates GST-CBP(2300-2441) without a priming phosphorylation, a computer-assisted analysis of the C-terminal part of CBP aa 2300 to 2441 was performed. The idea was to look for potential GSK3 phosphorylation sites by using the phosphorylation consensus sequence of GSK3. An additional hint was provided by the fact that p300 behaves differently at the glucagon gene (Schinner et al., 2005). Thus, a relevant phosphorylation target might be determined by finding a GSK3 recognition sequence in CBP which is not conserved in p300. It was found that CBP(2300-2441) contains serine-2424 four amino acids $\mathrm{N}$-terminally from the acidic amino acid aspartate at position 2828, thus forming a putative GSK3 phosphorylation sequence (Fig. 18). Serine-2420 might then be phosphorylated subsequently, due to the prephosphorylated serine-2424, thus forming a GSK3 recognition sequence (Fig. 18).

Then, serine-2420 and serine-2424 were mutated to alanine. Additionally, the construct, containing the double mutation was prepared. The in vitro kinase assay with recombinant GSK3 $\beta$ revealed that the phosphorylation was significantly diminished by more than $80 \%$ by all mutations. The residual phosphorylation of the mutants might be explained by the fact that still other GSK3 $\beta$-targeted amino acids exist within the C-terminal part of CBP. The fact that the phosphorylation by GSK3 $\beta$ was diminished to a similar and large degree 
for GST-CBP(2300-2441)S2420A, GST-CBP(2300-2441)S2424A and GST-CBP(23002441)S2420A/S2424A, support the view that the phosphorylations of serine-2420 and serine-2424 may be interdependent.

\section{4 Inhibition by insulin of CBP-mediated transcriptional activity}

In order to test the functional significance of the GSK3 $\beta$ phosphorylation sites described above, transient transfection experiments using the alpha cell line InR1G9 were performed. GAL4-CBP(2040-2441)WT, GAL4-CBP(2040-2441)S2420A and GAL4CBP(2040-2441)S2424A were shown to activate gene transcription when the mutated glucagon reporter gene, in which both Pax6 binding sites within the G1 and G3 elements had been mutated into GAL4 binding sites, and 5xGal4(E1B)Luc were used. The double mutant conferred no basal activity (activity is equal to the activity of GAL4), with both reporter genes used. This might be due to very low expression of GAL4-CBP(20402441)S2420A/S2424A.

The transcriptional activity conferred by GAL4-CBP(2040-2441) to the doubly mutated glucagon promoter was inhibited by insulin. In contrast, insulin did not affect GAL4-CBP activity using a reporter gene with GAL4 binding sites in front of the minimal viral E1B promoter, indicating that the specific glucagon promoter context is required for the effect of insulin on CBP activity. The fact that GAL4-CBP does not confer insulin responsiveness to the $5 \times$ Gal4(E1B)Luc reporter gene is consistent with previous studies (Grzeskowiak et al., 2000) and may be explained by the assumption that CBP might adopt a different conformation and may function differently when bound to this artificial promoter ( $\mathrm{Hu}$ et al., 1999). The different CBP conformation might also induce interaction of CBP with different cofactors or/and general transcription factors (Korzus et al., 1998; Kurokawa et al., 1998). CBP and the closely related protein p300 are modular proteins with multiple functional domains (Eckner, 1996; Korzus et al., 1998; Kurokawa et al., 1998; Torchia et al., 1998). In addition to Pax6, other transcription factors that bind to the glucagon gene 5'-flanking region can interact with $\mathrm{CBP}$ including Beta2/E47/E12 basic helix-loop-helix proteins (Mutoh et al., 1998; Qu et al., 1998), NFATp (Fürstenau et al., 1999; Garcia-Rodriguez and Rao, 1998), Ets-like transcription factors (Fürstenau et al., 1997; Yang et al., 1998), and CREB (Oetjen et al., 1994; Knepel et al., 1990; Kwok et al., 1994). The functional domains of $\mathrm{CBP}$ are differentially used by different transcription factors, implying conformational differences in the CBP-based coactivator complex bound to different classes of transcription factors (Korzus et al., 1998; Kurokawa et al., 1998). Thus, through multiple contacts with CBP or through recruiting other coactivators, the specific glucagon 
promoter context may induce the formation of a promoter-specific nucleoprotein complex (Shikama et al., 1997). Pax6 and CBP may be essential components of such a complex, which integrates the activities of proximal promoter elements and more distal enhancerlike elements and the function of which is sensitive to insulin (Grzeskowiak et al., 2000). The fact, that the introduced mutations do not influence the inhibition of glucagon gene transcription by insulin, provides the evidence that insulin and GSK3 might regulate CBP also by the phosphorylation of additional amino acids, which are not identified yet.

\section{5 Mutation of serine 2424 within CBP reduces the activation by GSK3 $\beta$ of glucagon gene transcription}

The role of the GSK3 $\beta$ phosphorylation sites described above in the regulation by GSK3 $\beta$ of CBP transcriptional activity was addressed by overexpression of GSK3 $\beta$ wild type. For control, GSK3ß-R85A was overexpressed in parallel. The mutation of arginine-85 to alanine within GSK3ß leads to complete loss of kinase activity (Dominguez et al., 1995). Stimulation of CBP-dependent transcription was obtained only when the doubly mutated glucagon promoter was used. This is consistent with a previous study, when the role for protein kinase $B$, the upstream partner of GSK3 $\beta$ in this pathway, was investigated and the effect was observed only with the mutated glucagon promoter (Schinner et al., 2005). Results, obtained in this study, now show that the mutation of serine-2424 within CBP significantly reduces the activation by GSK3 $\beta$ of CBP-dependent glucagon gene transcription.

However, this result might be due to unequal expression of the proteins. In order to exclude this possibility, the EMSA was performed. It showed that GAL4-CBP(20402441)WT and GAL4-CBP(2040-2441)S2424A are equally expressed within the cell. The findings thus suggest that CBP activity at the glucagon gene might be directly regulated by GSK3 $\beta$-mediated phosphorylation of serine-2424.

\section{6 Final Concept}

Protein phosphorylation plays a central role in signaling pathways by providing the means for transducing extracellular signals and coordinating intracellular events. It is a major regulator of the processes of gene expression and protein synthesis which determine cell growth, division or differentiation (Schonthal, 1995; Kennely et al., 1996). Since protein phosphorylation occurs by the reaction of protein kinases, a great body of research has 
been focused on studies of the structure and function of these enzymes. Our data show that serine-2424 of CBP is phosphorylated by GSK3 $\beta$ in vitro. In vivo studies showed that mutation of serine-2424 is sufficient to markedly reduce the activation of glucagon gene transcription by GSK3 $\beta$. The fact, that this mutation is not sufficient to interfere with the inhibitory effect of insulin on glucagon gene transcription, suggests that additional GSK3 $\beta$ phosphorylation sites exist.

In sum, we propose the following model of the inhibition of glucagon gene transcription by insulin. Under the fasting state, GSK3 $\beta$ is constitutively active and phosphorylates CBP, thus stabilizing the nucleoprotein complex on the glucagon promoter. CBP mediates glucagon gene transcription due to its intrinsic acetyltransferase activity. Under the fed state, insulin binds to its receptor activating the $\mathrm{PI}(3) \mathrm{K} / \mathrm{PKB}$ pathway. Phosphorylated $\mathrm{PKB}$ is becoming active and phosphorylates GSK3 $\beta$, which is known to be inactive when phosphorylated on its serine-9. CBP phosphorylation is no longer taking place leading to the destabilization of the nucleoprotein complex resulting in the inhibition of the glucagon gene transcription (Fig. 30).

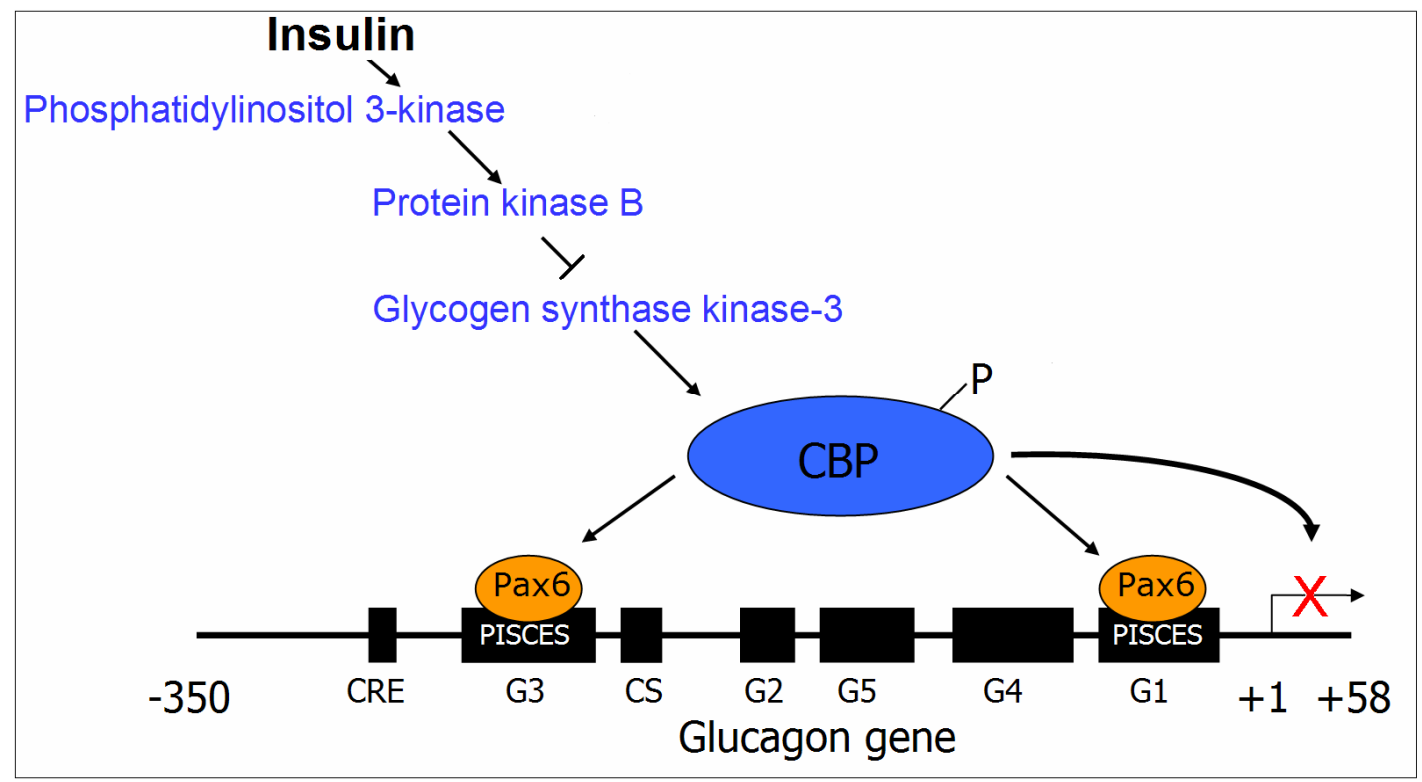

Fig. 30 Inhibition of glucagon gene transcription by insulin via $\mathrm{PI}(3) \mathrm{K} / \mathrm{PKB} / \mathrm{GSK} 3 \beta$ pathway involving phosphorylated CBP. Working hypothesis: phosphorylation of CBP at serine-2424 may be involved in the regulation by GSK3 $\beta$ of CBP transcriptional activity

In the absence of insulin GSK3 is constitutively active and phosphorylates CBP on serine2424("P"), thus stabilizing nucleoprotein complex on the glucagon promoter. Insulin induces activation of $\mathrm{PI}(3) \mathrm{K}$, which leads to the phosphorylation of protein kinase $\mathrm{B}$. Active PKB inhibits GSK3 $\beta$ by direct phosphorylation resulting in the inhibition of glucagon gene transcription. 


\section{7 Pharmacological inhibition of GSK3 - a strategy for the treatment of type 2 diabetes mellitus}

The most widely used antidiabetic drugs regulate blood glucose level by stimulating insulin secretion (sulfonylureas) or increasing insulin sensitivity (thiazolidinediones). However, drugs with a novel mechanism of action are required (Cohen and Goedert, 2004).

In the late 1990s a class of maleimides, that inhibited GSK3 much more potently than lithium, was identified. It was shown, that maleimide compounds inhibit glucagon gene transcription thus mimicking insulin action (Dimopoulos N., PhD Thesis, 2003). The following findings indicate that deficient inhibitory control of GSK3 is an important factor in type 2 diabetes mellitus and that inhibitors of GSK3 could be therapeutically beneficial. First, insulin promotes the dephosphorylation and activation of glycogen synthase by suppressing GSK3 activity (Cohen, 1999). Second, it has been reported that the expression of GSK3 is elevated in diabetic muscle (Eldar-Finkelman et al., 1999). Third, in overexpression studies, GSK3 could mimic the ability of insulin to promote the conversion of glucose to glycogen, overcoming the resistance of insulin, which is likely caused by blockade of the pathway at the level of the insulin receptor and insulin receptor substrate proteins (Eldar-Finkelman et al., 1997).

In contrast to stroke - a disease, which requires the short-term application of the GSK3 inhibitors - diabetes mellitus requires chronic administration of these compounds. Initially, it was concerned that due to the ubiquitous expression of GSK3 and its involvement in the regulation of the various cellular processes, long-term use of GSK3 inhibitors might be oncogenic (Polakis, 2002). Despite of that, recent findings suggest that the potential risk is significantly less than initially anticipated. For example, lithium salts have been used for bipolar-disorder treatment and their long-term use is not known to be associated with an increased risk of cancer (Frame and Zheleva, 2006). 


\section{Referensces}

Alessi D. R. and Cohen P. (1998). Mechanism of activation and function of protein kinase B. Curr Opin Genet Dev 8 (1): 55-62.

Alexander-Bridges M., Mukhopadhyay N. K., Jhala U., Denaro M., Kong X. F., Avruch J., and Maller J. (1992). Growth factor-activated kinases phosphorylate IRE-ABP. Biochem Soc Trans 20 (3): 691-693.

Ali A., Hoeflich K. P., and Woodgett J. R. (2001). Glycogen synthase kinase-3: properties, functions, and regulation. Chem Rev 101 (8): 2527-2540.

Andjelkovic M., Alessi D. R., Meier R., Fernandez A., Lamb N. J., Frech M., Cron P., Cohen P., Lucocq J. M., and Hemmings B. A. (1997). Role of translocation in the activation and function of protein kinase B. J Biol Chem 272 (50): 3151531524.

Areces L. B., Matafora V., and Bachi A. (2004). Analysis of protein phosphorylation by mass spectrometry. Eur J Mass Spectrom (Chichester, Eng) 10 (3): 383-392.

Barroso I. and Santisteban P. (1999). Insulin-induced early growth response gene (Egr-1) mediates a short term repression of rat malic enzyme gene transcription. $J$ Biol Chem 274 (25): 17997-18004.

Beals C. R., Sheridan C. M., Turck C. W., Gardner P., and Crabtree G. R. (1997). Nuclear export of NF-ATc enhanced by glycogen synthase kinase-3. Science 275 (5308): 1930-1934.

Birnbaum M. J. (1992). The insulin-sensitive glucose transporter. Int Rev Cytol 137: 239-297.

Blume-Jensen P. and Hunter T. (2001). Oncogenic kinase signalling. Nature 411 (6835): 355-365.

Boulton T. G., Nye S. H., Robbins D. J., Ip N. Y., Radziejewska E., Morgenbesser S. D., DePinho R. A., Panayotatos N., Cobb M. H., and Yancopoulos G. D. (1991). ERKs: a family of protein-serine/threonine kinases that are activated and tyrosine phosphorylated in response to insulin and NGF. Cell 65 (4): 663-675.

Boyle W. J., Smeal T., Defize L. H., Angel P., Woodgett J. R., Karin M., and Hunter T. (1991). Activation of protein kinase $C$ decreases phosphorylation of CJun at sites that negatively regulate its DNA-binding activity. Cell 64 (3): 573-584.

Bradford M. M. (1976). A rapid and sensitive method for the quantitation of microgram quantities of protein utilizing the principle of protein-dye binding. Anal Biochem 72: 248-254.

Carr S. A., Huddleston M. J., and Annan R. S. (1996). Selective detection and sequencing of phosphopeptides at the femtomole level by mass spectrometry. 
Anal Biochem 239 (2): 180-192.

Chapman S. C., Ayala J. E., Streeper R. S., Culbert A. A., Eaton E. M., Svitek C. A., Goldman J. K., Tavar J. M., and O'Brien R. M. (1999). Multiple promoter elements are required for the stimulatory effect of insulin on human collagenase-1 gene transcription. Selective effects on activator protein-1 expression may explain the quantitative difference in insulin and phorbol ester action. J Biol Chem 274 (26): 18625-18634.

Chawla S., Hardingham G. E., Quinn D. R., and Bading H. (1998). CBP: a signalregulated transcriptional coactivator controlled by nuclear calcium and CaM kinase IV. Science 281 (5382): 1505-1509.

Chrivia J. C., Kwok R. P., Lamb N., Hagiwara M., Montminy M. R., and Goodman R. H. (1993). Phosphorylated CREB binds specifically to the nuclear protein CBP. Nature 365 (6449): 855-859.

Chu B., Soncin F., Price B. D., Stevenson M. A., and Calderwood S. K. (1996). Sequential phosphorylation by mitogen-activated protein kinase and glycogen synthase kinase 3 represses transcriptional activation by heat shock factor-1. $J$ Biol Chem 271 (48): 30847-30857.

Cohen P. (1999). The Croonian Lecture 1998. Identification of a protein kinase cascade of major importance in insulin signal transduction. Philos Trans $R$ Soc Lond B Biol Sci 354 (1382): 485-495.

Cohen P. and Frame S. (2001). The renaissance of GSK3. Nat Rev Mol Cell Biol 2 (10): 769-776.

Cohen P. and Goedert M. (2004). GSK3 inhibitors: development and therapeutic potential. Nat Rev Drug Discov 3 (6): 479-487.

Dajani R., Fraser E., Roe S. M., Young N., Good V., Dale T. C., and Pearl L. H. (2001). Crystal structure of glycogen synthase kinase 3 beta: structural basis for phosphate-primed substrate specificity and autoinhibition. Cell 105 (6): 721-732.

DeFronzo R. A. (1997). Insulin resistance: a multifaceted syndrome responsible for NIDDM, obesity, hypertension, dyslipidaemia and atherosclerosis. Neth J Med 50 (5): 191-197.

Dent P., Campbell D. G., Hubbard M. J., and Cohen P. (1989). Multisite phosphorylation of the glycogen-binding subunit of protein phosphatase-1G by cyclic AMP-dependent protein kinase and glycogen synthase kinase-3. FEBS Lett 248 (1-2): 67-72.

Diehl J. A., Cheng M., Roussel M. F., and Sherr C. J. (1998). Glycogen synthase kinase-3beta regulates cyclin D1 proteolysis and subcellular localization. Genes Dev 12 (22): 3499-3511.

Dimopoulos N. (2003). A role for glycogen synthase kinase 3 beta In the regulation of glucagon gene transcription by insulin, Georg-August 
University Goettingen, Goettingen. . PhD Thesis.

Doble B. W. and Woodgett J. R. (2003). GSK-3: tricks of the trade for a multitasking kinase. J Cell Sci 116 (Pt 7): 1175-1186.

Dominguez I., Itoh K., and Sokol S. Y. (1995). Role of glycogen synthase kinase 3 beta as a negative regulator of dorsoventral axis formation in Xenopus embryos. Proc Natl Acad Sci U S A 92 (18): 8498-8502.

Downward J. (2001). The ins and outs of signalling. Nature 411 (6839): 759-762.

Drucker D. J., Philippe J., Jepeal L., and Habener J. F. (1987). Glucagon gene 5'flanking sequences promote islet cell-specific gene transcription. J Biol Chem 262 (32): 15659-15665.

Durham S. K., Suwanichkul A., Scheimann A. O., Yee D., Jackson J. G., Barr F. G., and Powell D. R. (1999). FKHR binds the insulin response element in the insulin-like growth factor binding protein-1 promoter. Endocrinology 140 (7): 31403146.

Eckner R., Yao T. P., Oldread E., and Livingston D. M. (1996). Interaction and functional collaboration of $\mathrm{p} 300 / \mathrm{CBP}$ and $\mathrm{bHLH}$ proteins in muscle and B-cell differentiation. Genes Dev 10 (19): 2478-2490.

Efrat S. (1998). Cell-based therapy for insulin-dependent diabetes mellitus. Eur J Endocrinol 138 (2): 129-133.

Eldar-Finkelman H. and Krebs E. G. (1997). Phosphorylation of insulin receptor substrate 1 by glycogen synthase kinase 3 impairs insulin action. Proc Natl Acad Sci U S A 94 (18): 9660-9664.

Eldar-Finkelman H., Schreyer S. A., Shinohara M. M., LeBoeuf R. C., and Krebs E. G. (1999). Increased glycogen synthase kinase-3 activity in diabetes- and obesity-prone C57BL/6J mice. Diabetes 48 (8): 1662-1666.

Fiol C. J., Haseman J. H., Wang Y. H., Roach P. J., Roeske R. W., Kowalczuk M., and DePaoli-Roach A. A. (1988). Phosphoserine as a recognition determinant for glycogen synthase kinase-3: phosphorylation of a synthetic peptide based on the G-component of protein phosphatase-1. Arch Biochem Biophys 267 (2): 797-802.

Fiol C. J., Mahrenholz A. M., Wang Y., Roeske R. W., and Roach P. J. (1987). Formation of protein kinase recognition sites by covalent modification of the substrate. Molecular mechanism for the synergistic action of casein kinase II and glycogen synthase kinase 3. J Biol Chem 262 (29): 14042-14048.

Fiol C. J., Wang A., Roeske R. W., and Roach P. J. (1990). Ordered multisite protein phosphorylation. Analysis of glycogen synthase kinase 3 action using model peptide substrates. J Biol Chem 265 (11): 6061-6065.

Frame S. and Cohen P. (2001). GSK3 takes centre stage more than 20 years after its discovery. Biochem J 359 (Pt 1): 1-16. 
Frame S., Cohen P., and Biondi R. M. (2001). A common phosphate binding site explains the unique substrate specificity of GSK3 and its inactivation by phosphorylation. Mol Cell 7 (6): 1321-1327.

Frame S. and Zheleva D. (2006). Targeting glycogen synthase kinase-3 in insulin signalling. Expert Opin Ther Targets 10 (3): 429-444.

Furstenau U., Schwaninger M., Blume R., Jendrusch E. M., and Knepel W. (1999). Characterization of a novel calcium response element in the glucagon gene. J Biol Chem 274 (9): 5851-5860.

Furstenau U., Schwaninger M., Blume R., Kennerknecht I., and Knepel W. (1997). Characterization of a novel protein kinase $C$ response element in the glucagon gene. Mol Cell Biol 17 (4): 1805-1816.

Garcia-Perez J., Avila J., and Diaz-Nido J. (1998). Implication of cyclin-dependent kinases and glycogen synthase kinase 3 in the phosphorylation of microtubuleassociated protein 1B in developing neuronal cells. J Neurosci Res 52 (4): 445452.

Garcia-Rodriguez C. and Rao A. (1998). Nuclear factor of activated T cells (NFAT)-dependent transactivation regulated by the coactivators p300/CREBbinding protein (CBP). J Exp Med 187 (12): 2031-2036.

Giles R. H., Petrij F., Dauwerse H. G., den Hollander A. I., Lushnikova T., van Ommen G. J., Goodman R. H., Deaven L. L., Doggett N. A., Peters D. J., and Breuning M. H. (1997). Construction of a 1.2-Mb contig surrounding, and molecular analysis of, the human CREB-binding protein (CBP/CREBBP) gene on chromosome 16p13.3. Genomics 42 (1): 96-114.

Goodman R. H. and Smolik S. (2000). CBP/p300 in cell growth, transformation, and development. Genes Dev 14 (13): 1553-1577.

Grimes C. A. and Jope R. S. (2001). CREB DNA binding activity is inhibited by glycogen synthase kinase-3 beta and facilitated by lithium. $J$ Neurochem 78 (6): 1219-1232.

Grzeskowiak R., Amin J., Oetjen E., and Knepel W. (2000). Insulin responsiveness of the glucagon gene conferred by interactions between proximal promoter and more distal enhancer-like elements involving the paired-domain transcription factor Pax6. J Biol Chem 275 (39): 30037-30045.

Grzeskowiak R. (2000a). Involvement of the paired-domain transcription factor Pax6 in the regulation of glucagon gene transcription by insulin, Georg-August University Goettingen, Goettingen. PhD Thesis.

Hagiwara M., Brindle P., Harootunian A., Armstrong R., Rivier J., Vale W., Tsien R., and Montminy M. R. (1993). Coupling of hormonal stimulation and transcription via the cyclic AMP-responsive factor CREB is rate limited by nuclear entry of protein kinase A. Mol Cell Biol 13 (8): 4852-4859. 
Hanger D. P., Hughes K., Woodgett J. R., Brion J. P., and Anderton B. H. (1992). Glycogen synthase kinase-3 induces Alzheimer's disease-like phosphorylation of tau: generation of paired helical filament epitopes and neuronal localisation of the kinase. Neurosci Lett 147 (1): 58-62.

Harootunian A. T., Adams S. R., Wen W., Meinkoth J. L., Taylor S. S., and Tsien R. Y. (1993). Movement of the free catalytic subunit of cAMP-dependent protein kinase into and out of the nucleus can be explained by diffusion. Mol Biol Cell 4 (10): 993-1002.

Hartigan J. A., Xiong W. C., and Johnson G. V. (2001). Glycogen synthase kinase 3beta is tyrosine phosphorylated by PYK2. Biochem Biophys Res Commun 284 (2): 485-489.

Harwood A. J. (2001). Regulation of GSK-3: a cellular multiprocessor. Cell 105 (7): 821-824.

Herzig S., Hedrick S., Morantte I., Koo S. H., Galimi F., and Montminy M. (2003). CREB controls hepatic lipid metabolism through nuclear hormone receptor PPARgamma. Nature 426 (6963): 190-193.

Hill M. M., Andjelkovic M., Brazil D. P., Ferrari S., Fabbro D., and Hemmings B. A. (2001). Insulin-stimulated protein kinase B phosphorylation on Ser-473 is independent of its activity and occurs through a staurosporine-insensitive kinase. $J$ Biol Chem 276 (28): 25643-25646.

Hirosumi J., Tuncman G., Chang L., Gorgun C. Z., Uysal K. T., Maeda K., Karin M., and Hotamisligil G. S. (2002). A central role for JNK in obesity and insulin resistance. Nature 420 (6913): 333-336.

Hoeflich K. P., Luo J., Rubie E. A., Tsao M. S., Jin O., and Woodgett J. R. (2000). Requirement for glycogen synthase kinase-3beta in cell survival and NF-kappaB activation. Nature 406 (6791): 86-90.

Hotamisligil G. S., Peraldi P., Budavari A., Ellis R., White M. F., and Spiegelman B. M. (1996). IRS-1-mediated inhibition of insulin receptor tyrosine kinase activity in TNF-alpha- and obesity-induced insulin resistance. Science 271 (5249): 665668.

Hu S. C., Chrivia J., and Ghosh A. (1999). Regulation of CBP-mediated transcription by neuronal calcium signaling. Neuron 22 (4): 799-808.

Hughes K., Nikolakaki E., Plyte S. E., Totty N. F., and Woodgett J. R. (1993). Modulation of the glycogen synthase kinase-3 family by tyrosine phosphorylation. Embo J 12 (2): 803-808.

Hughes K., Ramakrishna S., Benjamin W. B., and Woodgett J. R. (1992). Identification of multifunctional ATP-citrate lyase kinase as the alpha-isoform of glycogen synthase kinase-3. Biochem J 288 ( Pt 1): 309-314. 
Hunter M. and Giebisch G. (1988). Calcium-activated K-channels of Amphiuma early distal tubule: inhibition by ATP. Pflugers Arch 412 (3): 331-333.

Hussain M. A. and Habener J. F. (1999). Glucagon gene transcription activation mediated by synergistic interactions of pax- 6 and cdx-2 with the p300 co-activator. J Biol Chem 274 (41): 28950-28957.

Ikeda S., Kishida S., Yamamoto H., Murai H., Koyama S., and Kikuchi A. (1998). Axin, a negative regulator of the Wnt signaling pathway, forms a complex with GSK-3beta and beta-catenin and promotes GSK-3beta-dependent phosphorylation of beta-catenin. Embo J 17 (5): 1371-1384.

Impey S., Fong A. L., Wang Y., Cardinaux J. R., Fass D. M., Obrietan K., Wayman G. A., Storm D. R., Soderling T. R., and Goodman R. H. (2002). Phosphorylation of CBP mediates transcriptional activation by neural activity and CaM kinase IV. Neuron 34 (2): 235-244.

Jho E., Lomvardas S., and Costantini F. (1999). A GSK3beta phosphorylation site in axin modulates interaction with beta-catenin and Tcf-mediated gene expression. Biochem Biophys Res Commun 266 (1): 28-35.

Jiang G. and Zhang B. B. (2003). Glucagon and regulation of glucose metabolism. Am J Physiol Endocrinol Metab 284 (4): E671-678.

Kahn S. E. (2003). The relative contributions of insulin resistance and beta-cell dysfunction to the pathophysiology of Type 2 diabetes. Diabetologia 46 (1): 3-19.

Kido Y., Burks D. J., Withers D., Bruning J. C., Kahn C. R., White M. F., and Accili D. (2000). Tissue-specific insulin resistance in mice with mutations in the insulin receptor, IRS-1, and IRS-2. J Clin Invest 105 (2): 199-205.

King H., Aubert R. E., and Herman W. H. (1998). Global burden of diabetes, 19952025: prevalence, numerical estimates, and projections. Diabetes Care 21 (9): 1414-1431.

Kirschenbaum F., Hsu S. C., Cordell B., and McCarthy J. V. (2001). Glycogen synthase kinase-3beta regulates presenilin $1 \mathrm{C}$-terminal fragment levels. $\mathrm{J}$ Biol Chem 276 (33): 30701-30707.

Knepel W. (1993). Transcriptional control of pancreatic islet hormones gene expression. Exp Clin Endocrinol 101 (1): 39-45.

Knepel W. (2001). Chapter 5: The a-cell and regulation of glucagon gene transcription. From the textbook of Habener Jf, Hussain MA "Molecular basis of pancreas development and function". Kluwer Academic Publishers.

Knepel W., Chafitz J., and Habener J. F. (1990). Transcriptional activation of the rat glucagon gene by the cyclic AMP-responsive element in pancreatic islet cells. Mol Cell Biol 10 (12): 6799-6804.

Knepel W., Jepeal L., and Habener J. F. (1990). A pancreatic islet cell-specific 
enhancer-like element in the glucagon gene contains two domains binding distinct cellular proteins. J Biol Chem 265 (15): 8725-8735.

Kohn A. D., Summers S. A., Birnbaum M. J., and Roth R. A. (1996). Expression of a constitutively active Akt Ser/Thr kinase in 3T3-L1 adipocytes stimulates glucose uptake and glucose transporter 4 translocation. J Biol Chem 271 (49): 3137231378.

Korzus E., Torchia J., Rose D. W., Xu L., Kurokawa R., Mclnerney E. M., Mullen T. M., Glass C. K., and Rosenfeld M. G. (1998). Transcription factor-specific requirements for coactivators and their acetyltransferase functions. Science 279 (5351): 703-707.

Krüger M., Schwaninger M., Blume R., Oetjen E., and Knepel W. (1997). Inhibition of CREB- and CAMP response element-mediated gene transcription by the immunosuppressive drugs cyclosporin A and FK506 in T cells. Naunyn Schmiedebergs Arch Pharmacol 356 (4): 433-440.

Kurokawa R., Kalafus D., Ogliastro M. H., Kioussi C., Xu L., Torchia J., Rosenfeld M. G., and Glass C. K. (1998). Differential use of CREB binding protein-coactivator complexes. Science 279 (5351): 700-703.

Kwok R. P., Lundblad J. R., Chrivia J. C., Richards J. P., Bachinger H. P., Brennan R. G., Roberts S. G., Green M. R., and Goodman R. H. (1994). Nuclear protein CBP is a coactivator for the transcription factor CREB. Nature 370 (6486): 223-226.

Kyriakis J. M., App H., Zhang X. F., Banerjee P., Brautigan D. L., Rapp U. R., and Avruch J. (1992). Raf-1 activates MAP kinase-kinase. Nature 358 (6385): 417-421.

Lawrence J. C., Jr. and Roach P. J. (1997). New insights into the role and mechanism of glycogen synthase activation by insulin. Diabetes 46 (4): 541-547.

Lazar D. F., Wiese R. J., Brady M. J., Mastick C. C., Waters S. B., Yamauchi K., Pessin J. E., Cuatrecasas P., and Saltiel A. R. (1995). Mitogen-activated protein kinase kinase inhibition does not block the stimulation of glucose utilization by insulin. J Biol Chem 270 (35): 20801-20807.

Le Roith D. and Zick Y. (2001). Recent advances in our understanding of insulin action and insulin resistance. Diabetes Care 24 (3): 588-597.

Leahy P., Crawford D. R., Grossman G., Gronostajski R. M., and Hanson R. W. (1999). CREB binding protein coordinates the function of multiple transcription factors including nuclear factor I to regulate phosphoenolpyruvate carboxykinase (GTP) gene transcription. J Biol Chem 274 (13): 8813-8822.

Lee C. S., Sund N. J., Vatamaniuk M. Z., Matschinsky F. M., Stoffers D. A., and Kaestner K. H. (2002). Foxa2 controls Pdx1 gene expression in pancreatic betacells in vivo. Diabetes 51 (8): 2546-2551.

Lesort M., Jope R. S., and Johnson G. V. (1999). Insulin transiently increases tau 
phosphorylation: involvement of glycogen synthase kinase-3beta and Fyn tyrosine kinase. J Neurochem 72 (2): 576-584.

Li T. and Paudel H. K. (2006). Glycogen synthase kinase 3beta phosphorylates Alzheimer's disease-specific Ser396 of microtubule-associated protein tau by a sequential mechanism. Biochemistry 45 (10): 3125-3133.

Meda P., Kohen E., Kohen C., Rabinovitch A., and Orci L. (1982). Direct communication of homologous and heterologous endocrine islet cells in culture. $J$ Cell Biol 92 (1): 221-226.

Meier R., Alessi D. R., Cron P., Andjelkovic M., and Hemmings B. A. (1997). Mitogenic activation, phosphorylation, and nuclear translocation of protein kinase Bbeta. J Biol Chem 272 (48): 30491-30497.

Meyer T. E. and Habener J. F. (1993). Cyclic adenosine 3',5'-monophosphate response element binding protein (CREB) and related transcription-activating deoxyribonucleic acid-binding proteins. Endocr Rev 14 (3): 269-290.

Michaels R. L. and Sheridan J. D. (1981). Islets of Langerhans: dye coupling among immunocytochemically distinct cell types. Science 214 (4522): 801-803.

Mikkola I., Bruun J. A., Bjorkoy G., Holm T., and Johansen T. (1999). Phosphorylation of the transactivation domain of Pax6 by extracellular signalregulated kinase and p38 mitogen-activated protein kinase. J Biol Chem 274 (21): $15115-15126$.

Morel C., Cordier-Bussat M., and Philippe J. (1995). The upstream promoter element of the glucagon gene, G1, confers pancreatic alpha cell-specific expression. J Biol Chem 270 (7): 3046-3055.

Morisco C., Seta K., Hardt S. E., Lee Y., Vatner S. F., and Sadoshima J. (2001). Glycogen synthase kinase 3 beta regulates GATA4 in cardiac myocytes. J Biol Chem 276 (30): 28586-28597.

Mutoh H., Naya F. J., Tsai M. J., and Leiter A. B. (1998). The basic helix-loop-helix protein BETA2 interacts with p300 to coordinate differentiation of secretinexpressing enteroendocrine cells. Genes Dev 12 (6): 820-830.

Nakajima T., Fukamizu A., Takahashi J., Gage F. H., Fisher T., Blenis J., and Montminy M. R. (1996). The signal-dependent coactivator CBP is a nuclear target for pp90RSK. Cell 86 (3): 465-474.

O'Brien R. M. and Granner D. K. (1996). Regulation of gene expression by insulin. Physiol Rev 76 (4): 1109-1161.

Oetjen E., Diedrich T., Eggers A., Eckert B., and Knepel W. (1994). Distinct properties of the cAMP-responsive element of the rat insulin I gene. $\mathrm{J}$ Biol Chem 269 (43): 27036-27044.

Orci L., Malaisse-Lagae F., Ravazzola M., Rouiller D., Renold A. E., Perrelet A., 
and Unger R. (1975). A morphological basis for intercellular communication between alpha- and beta-cells in the endocrine pancreas. J Clin Invest 56 (4): 1066-1070.

Orci L. and Unger R. H. (1975). Functional subdivision of islets of Langerhans and possible role of D cells. Lancet 2 (7947): 1243-1244.

Park I. K., Roach P., Bondor J., Fox S. P., and DePaoli-Roach A. A. (1994). Molecular mechanism of the synergistic phosphorylation of phosphatase inhibitor2. Cloning, expression, and site-directed mutagenesis of inhibitor-2. J Biol Chem 269 (2): 944-954.

Pawson T. and Scott J. D. (1997). Signaling through scaffold, anchoring, and adaptor proteins. Science 278 (5346): 2075-2080.

Pessin J. E. and Saltiel A. R. (2000). Signaling pathways in insulin action: molecular targets of insulin resistance. J Clin Invest 106 (2): 165-169.

Pessin J. E., Thurmond D. C., Elmendorf J. S., Coker K. J., and Okada S. (1999). Molecular basis of insulin-stimulated GLUT4 vesicle trafficking. Location! Location! Location! J Biol Chem 274 (5): 2593-2596.

Phiel C. J., Wilson C. A., Lee V. M., and Klein P. S. (2003). GSK-3alpha regulates production of Alzheimer's disease amyloid-beta peptides. Nature 423 (6938): 435439.

Philippe J. (1989). Glucagon gene transcription is negatively regulated by insulin in a hamster islet cell line. J Clin Invest 84 (2): 672-677.

Philippe J. (1991). Insulin regulation of the glucagon gene is mediated by an insulin-responsive DNA element. Proc Natl Acad Sci U S A 88 (16): 7224-7227.

Philippe J., Drucker D. J., Knepel W., Jepeal L., Misulovin Z., and Habener J. F. (1988). Alpha-cell-specific expression of the glucagon gene is conferred to the glucagon promoter element by the interactions of DNA-binding proteins. Mol Cell Biol 8 (11): 4877-4888.

Pierreux C. E., Rousseau G. G., and Lemaigre F. P. (1999). Insulin inhibition of glucocorticoid-stimulated gene transcription: requirement for an insulin response element? Mol Cell Endocrinol 147 (1-2): 1-5.

Polakis P. (2002). Casein kinase 1: a Wnt'er of disconnect. Curr Biol 12 (14): R499-R501.

Pulverer B. J., Fisher C., Vousden K., Littlewood T., Evan G., and Woodgett J. R. (1994). Site-specific modulation of c-Myc cotransformation by residues phosphorylated in vivo. Oncogene 9 (1): 59-70.

Qiu Y., Sharma A., and Stein R. (1998). p300 mediates transcriptional stimulation by the basic helix-loop-helix activators of the insulin gene. Mol Cell Biol 18 (5): 2957-2964. 
Reaven G. M. (1988). Banting lecture 1988. Role of insulin resistance in human disease. Diabetes 37 (12): 1595-1607.

Ross S. E., Erickson R. L., Hemati N., and MacDougald O. A. (1999). Glycogen synthase kinase 3 is an insulin-regulated C/EBPalpha kinase. Mol Cell Biol 19 (12): 8433-8441.

Rubinfeld B., Albert I., Porfiri E., Fiol C., Munemitsu S., and Polakis P. (1996). Binding of GSK3beta to the APC-beta-catenin complex and regulation of complex assembly. Science 272 (5264): 1023-1026.

Salazar M., Rojo A. I., Velasco D., de Sagarra R. M., and Cuadrado A. (2006). Glycogen synthase kinase-3beta inhibits the xenobiotic and antioxidant cell response by direct phosphorylation and nuclear exclusion of the transcription factor Nrf2. J Biol Chem 281 (21): 14841-14851.

Sambrook J., Fritsch E. F., and Maniatis T. (1989). Molecular cloning. A laboratory manual. 2-nd edition Cold Spring Harbor Laboratory.

Schinner S., Barthel A., Dellas C., Grzeskowiak R., Sharma S. K., Oetjen E., Blume R., and Knepel W. (2005). Protein kinase B activity is sufficient to mimic the effect of insulin on glucagon gene transcription. J Biol Chem 280 (8): 7369-7376.

Schonthal A. H. (1995). Regulation of gene expression by serine/threonine protein phosphatases. Semin Cancer Biol 6 (4): 239-248.

Schwabe R. F. and Sakurai H. (2005). IKKbeta phosphorylates p65 at S468 in transactivaton domain 2. Faseb J 19 (12): 1758-1760.

Schwaninger M., Blume R., Oetjen E., Lux G., and Knepel W. (1993). Inhibition of cAMP-responsive element-mediated gene transcription by cyclosporin $A$ and FK506 after membrane depolarization. J Biol Chem 268 (31): 23111-23115.

Shikama N., Lyon J., and La Thangue N. (1997). The p300/CBP family: integrating signals with transcription factors and chromatin. Trends Cell Biol 7: 230-236.

Summers S. A., Yin V. P., Whiteman E. L., Garza L. A., Cho H., Tuttle R. L., and Birnbaum M. J. (1999). Signaling pathways mediating insulin-stimulated glucose transport. Ann N Y Acad Sci 892: 169-186.

Takaki R., Ono J., Nakamura M., Yokogawa Y., Kumae S., Hiraoka T., Yamaguchi K., Hamaguchi K., and Uchida S. (1986). Isolation of glucagon-secreting cell lines by cloning insulinoma cells. In Vitro Cell Dev Biol 22 (3 Pt 1): 120-126.

Tatusova T. A. and Madden T. L. (1999). BLAST 2 Sequences, a new tool for comparing protein and nucleotide sequences. FEMS Microbiol Lett 174 (2): 247250.

Thomas G. M., Frame S., Goedert M., Nathke I., Polakis P., and Cohen P. (1999). A GSK3-binding peptide from FRAT1 selectively inhibits the GSK3-catalysed 
phosphorylation of axin and beta-catenin. FEBS Lett 458 (2): 247-251.

Thompson M. J., Roe M. W., Malik R. K., and Blackshear P. J. (1994). Insulin and other growth factors induce binding of the ternary complex and a novel protein complex to the c-fos serum response element. J Biol Chem 269 (33): 2112721135.

Torchia J., Glass C., and Rosenfeld M. G. (1998). Co-activators and co-repressors in the integration of transcriptional responses. Curr Opin Cell Biol 10 (3): 373-383.

Tripathi B. K. and Srivastava A. K. (2006). Diabetes mellitus: complications and therapeutics. Med Sci Monit 12 (7): RA130-147.

Trivedi N., Marsh P., Goold R. G., Wood-Kaczmar A., and Gordon-Weeks P. R. (2005). Glycogen synthase kinase-3beta phosphorylation of MAP1B at Ser1260 and Thr1265 is spatially restricted to growing axons. J Cell Sci 118 (Pt 5): 9931005.

Twomey C. and McCarthy J. V. (2006). Presenilin-1 is an unprimed glycogen synthase kinase-3beta substrate. FEBS Lett 580 (17): 4015-4020.

Ugai H., Uchida K., Kawasaki H., and Yokoyama K. K. (1999). The coactivators p300 and CBP have different functions during the differentiation of F9 cells. $J \mathrm{Mol}$ Med 77 (6): 481-494.

Unger R. H., Dobbs R. E., and Orci L. (1978). Insulin, glucagon, and somatostatin secretion in the regulation of metabolism. Annu Rev Physiol 40: 307-343.

Unger R. H. and Orci L. (1981). Glucagon and the A cell: physiology and pathophysiology (first two parts). N Engl J Med 304 (25): 1518-1524.

van Montfort B. A., Canas B., Duurkens R., Godovac-Zimmermann J., and Robillard G. T. (2002). Improved in-gel approaches to generate peptide maps of integral membrane proteins with matrix-assisted laser desorption/ionization timeof-flight mass spectrometry. J Mass Spectrom 37 (3): 322-330.

van Montfort B. A., Doeven M. K., Canas B., Veenhoff L. M., Poolman B., and Robillard G. T. (2002). Combined in-gel tryptic digestion and CNBr cleavage for the generation of peptide maps of an integral membrane protein with MALDI-TOF mass spectrometry. Biochim Biophys Acta 1555 (1-3): 111-115.

Vanhaesebroeck B. and Alessi D. R. (2000). The PI3K-PDK1 connection: more than just a road to PKB. Biochem J 346 Pt 3: 561-576.

Vidal-Puig A. and O'Rahilly S. (2001). Metabolism. Controlling the glucose factory. Nature 413 (6852): 125-126.

Virkamaki A., Ueki K., and Kahn C. R. (1999). Protein-protein interaction in insulin signaling and the molecular mechanisms of insulin resistance. J Clin Invest 103 (7): 931-943. 
Welsh G. I. and Proud C. G. (1993). Glycogen synthase kinase-3 is rapidly inactivated in response to insulin and phosphorylates eukaryotic initiation factor elF-2B. Biochem J 294 ( Pt 3): 625-629.

Weston C. R. and Davis R. J. (2001). Signal transduction: signaling specificity- a complex affair. Science 292 (5526): 2439-2440.

Wilson I. A., Niman H. L., Houghten R. A., Cherenson A. R., Connolly M. L., and Lerner R. A. (1984). The structure of an antigenic determinant in a protein. Cell 37 (3): 767-778.

Woodgett J. R. (2005). Recent advances in the protein kinase B signaling pathway. Curr Opin Cell Biol 17 (2): 150-157.

Yan J. X., Packer N. H., Gooley A. A., and Williams K. L. (1998). Protein phosphorylation: technologies for the identification of phosphoamino acids. $J$ Chromatogr A 808 (1-2): 23-41.

Yang C., Shapiro L. H., Rivera M., Kumar A., and Brindle P. K. (1998). A role for CREB binding protein and p300 transcriptional coactivators in Ets-1 transactivation functions. Mol Cell Biol 18 (4): 2218-2229.

Yost C., Torres M., Miller J. R., Huang E., Kimelman D., and Moon R. T. (1996). The axis-inducing activity, stability, and subcellular distribution of beta-catenin is regulated in Xenopus embryos by glycogen synthase kinase 3. Genes Dev 10 (12): 1443-1454.

Yuan Z. M., Huang Y., Ishiko T., Nakada S., Utsugisawa T., Shioya H., Utsugisawa Y., Yokoyama K., Weichselbaum R., Shi Y., and Kufe D. (1999). Role for p300 in stabilization of p53 in the response to DNA damage. J Biol Chem 274 (4): 1883-1886.

Zhou X. Y., Shibusawa N., Naik K., Porras D., Temple K., Ou H., Kaihara K., Roe M. W., Brady M. J., and Wondisford F. E. (2004). Insulin regulation of hepatic gluconeogenesis through phosphorylation of CREB-binding protein. Nat Med 10 (6): 633-637.

Zick Y. (2001). Insulin resistance: a phosphorylation-based uncoupling of insulin signaling. Trends Cell Biol 11 (11): 437-441.

Zimmet P., Alberti K. G., and Shaw J. (2001). Global and societal implications of the diabetes epidemic. Nature 414 (6865): 782-787. 


\section{Acknowledgements}

I want to express gratitude to Professor Willhart Knepel for the opportunity he gave me to work in this department and for his encouragement to perform this study.

I am very grateful to Professor Gerhard Burckhardt, a leader of GRK 335, for giving me the opportunity to be a scholar in the frame of GRK "Clinical, Cellular and Molecular Biology of Internal Organs" and for his warm encouragement and help in every respect.

I am thankful to Professor Rüdiger Hardeland for reviewing my $\mathrm{PhD}$ thesis and to Professor Detlef Doenecke for being my coreviewer.

I want to give special thanks to Dr. Elke Oetjen for her constant support and for her supervision in organizing of my experimental work. Also I appreciate the time she spent for patient reading and correction of my thesis.

I appreciate contribution of Dr. Ulrike Böer to my project by helpful advices and discussions.

My sincere thanks to Dr. Sanjeev Sharma for his practical advices and for patient answering my questions and for every kind of support.

I appreciate the help and cooperation of Dr. Hasan Dihazi for performing MALDI-TOF analysis.

I would like to thank R. Blume, C. Dickel, D. Krause and I. Cierny for their excellent technical assistance.

I am thankful to Marcel, Alena and Katja for their helpful scientific advices.

I thank all my colleagues, with whom I worked side by side and day by day in the department, for the creation of scientific working atmosphere.

Finally, I want to give a very special thanks to my parents and friends for their moral support that was so necessary for me during this whole period. 


\title{
Curriculum Vitae
}

\author{
Name \\ Andrei Matsiulka \\ Date of birth \\ 13.09.1980 \\ Place of birth \\ Vileyka, Belarus \\ Citizenship \\ Belarusian \\ $1986-1997$ \\ School education \\ Secondary school №3, Vileyka, Belarus \\ $1997-2002$ \\ University Study \\ Chemistry faculty \\ Belarusian State University \\ Minsk, Belarus \\ 2002 \\ Diploma with honors \\ Defense of Diploma scientific project "Production and \\ Research of Sulphated Xylan Biological Activity" \\ Qualification: Chemist, Pharmaceutical Chemist \\ 2003 \\ Master Diploma \\ Defense of Master scientific project "Nitric-acid Method of the \\ Entherosorbent Production based on the Carboxylated \\ Mycrocrystalline Cellulose", \\ Degree: Master of Science in chemistry with specialization in \\ high molecular compounds \\ PhD Student \\ Experimental work for the present dissertation in the \\ Department of Molecular Pharmacology of the Georg-August \\ University (Göttingen) in the frame of GRK 335 "Clinical, \\ Cellular and Molecular Biology of Internal Organs“. \\ Dissertation title: "Regulation by Glycogen Synthase Kinase-3 \\ Beta of CBP transcriptional coactivator involved in insulin- \\ dependent glucagon gene transcription"
}

